\title{
Proses dan Elemen-Elemen Komunikasi Politik
}

\author{
mirzashahreza@gmail.com
}

"Setiap kamu adalah pemimpin dan setiap kamu akan ditanya tentang apa yang dipimpinnya. Imam (waliyul amri) yang memerintah manusia adalah pemimpin dan ia akan ditanya tentang rakyatnya." (Al-Hadist) ${ }^{1}$

Sering kita mendengar kata komunikator politik atau lebih familiar dengan sebutan sebagai politikus. Bahkan selama ini publik menganggap bahwa komunikator politik adalah bagi mereka yang berkecimpung dalam dunia politik saja. Sebagai contoh beberapa nama seperti Ruhut Sitompul, Jokowi, Prabowo, SBY, Anas Urbaningrum dan Megawati, tentu semua yakin bahwa mereka adalah komunikator politik. Berbeda ketika menyebut nama si fulan, bang Jali, bu Ijah, mpo Nori yang mungkin mereka dari berbagai profesi seperti pengusaha, pegawai, mahasiswa, tukang ojek, tukang sayur, tukang es cendol dan sebagainya. Dari sekian nama tersebut apakah anda akan memberikan label kepada mereka sebagai komunikator politik?

Menurut buku komunikasi politik yang ditulis oleh Dan Nimmo (1998), ternyata kita semua termasuk komunikator politik, mulai dari suara keluhan tukang ojek terhadap kenaikan harga BBM, obrolan mahasiswa diruang kelas, sampai seorang presiden yang membuat kebijakan publik. Komunikator politik tidak hanya disandang oleh mereka yang mempunyai nama yang besar saja tetapi juga mereka yang tidak mempunyai nama sekalipun atau rakyat biasa. Tapi bagaimanapun juga mereka mempunyai wilayah dan kapasitas masing-masing sebagaimana profesi dan peran mereka di masyarakat .

Komunikasi politik adalah suatu proses penyampaian pesan-pesan politik yang berasal dari komunikator politik (source, encoder, sender, actor) sebagai pihak yang memulai dan mengarahkan suatu tindakan komunikasi. ${ }^{2}$ Lalu pesan-pesan tersebut ditujukan kepada khalayak (receiver, komunikan), dengan menggunakan media (channel, saluran) tertentu untuk mencapai sautu tujuan yang telah ditentukan (political oriented). Dalam sistem politik semua komponen-komponen tersebut merupakan proses atau kegiatan

\footnotetext{
${ }^{1}$ Hadits riwayat Al-Bukhâri dalam shahîhnya (893) dan Muslim (4828).

2 Zulkarimein Nasution, Komunikasi Politik Suatu Pengantar, Jakarta: Ghalia Indonesia, 1990, hlm. 43
} 
komunikasi politik yang merupakan input yang menentukan output daripada sistem politik.

Menurut Gurevitch dan Blumler (1977) ${ }^{3}$ menjelaskan bahwa dalam arti yang luas, komponen-komponen utama dari suatu sistem komunikasi politik ditemukan pada:

1. Lembaga-lembaga politik dalam aspek-aspek komunikasinya,

2. Institusi-institusi media dalam aspek-aspek politiknya,

3. Orientasi khalayak terhadap komunkasi politik,

4. Aspek-aspek budaya politik yang relevan dengan komunikasi.

Sehingga sistem komunikasi politik dapat dilihat dalam dua perspektif, yaitu perangkat institusi politik dan organisasi media yang terlibat dalam persiapan pesan bagi interaksi yang lebih horizontal satu sama lain, sedangkan dalam arah yang vertical institusi-institusi tadi baik secara terpisah maupun bersama-sama melakukan diseminasi dan pengolahan informasi dan gagasan dari dan untuk masyarakat.

\section{a. Komunikator Politik}

Meskipun setiap orang boleh berkomunikasi tentang politik, namun yang melakukannya secara tetap dan berkesinambungan jumlahnya relatif sedikit. Walaupun sedikit, para komunikator politik ini memainkan peran sosial yang utama, terutama dalam proses opini publik. Leonard W. Doob mengklasifikasikan komunikator utama dalam politik sebagai politikus, professional, dan aktivis. Para komunikator politik tersebut merupakan kombinasi dari beberapa unsur profesi dengan latar belakang yang berbeda. Dan bahan bakunya adalah dari masyarakat itu sendiri (rakyat). Menurut Socrates ${ }^{5}$, keadilan (justice) merupakan tujuan politik yang layak. Ini disebabkan keadilan merupakan hal yang esensial bagi pemenuhan kecendrungan alamiah manusia. Menempatkan keadilan sebagai patokan tertinggi sama dengan memandang tujuan kehidupan politik sebagai aktualisasi bakatt-bakat manusia. Baginya, keadilan ialah melaksanakan apa yang menjadi fungsi atau pekerjaannya sendiri sebaik-baiknya tanpa mencampuri fungsi atau pekerjaan orang lain (the practice of minding one's own business).

Fungsi setiap pihak dalam masyarakat ialah berupa apa yang ia sendiri dapat lakukan atau sesuatu yang dapat ia laksanakan secara lebih baik daripada mengerjakan hal yang lain. Dan setiap hal yang dikerjakan mengandung kebajikan (virtue) tersendiri. Yang menjadi patokan kebaikan

\footnotetext{
${ }^{3}$ Ibid, hlm. 42

${ }^{4}$ Dan Nimmo, Komunikasi Politik: Komunikator, Pesan, dan Media, Bandung: PT Remaja Rosdakarya, 2005, hlm. 30

${ }^{5}$ Ramlan Surbakti, Memahami Ilmu Politik, Jakarta: Gramedia Widya Pustaka Utama, 1992, hlm 30-31
} 
ialah secara alamiah sangat sesuai, yakni kebajikan setiap hal untuk melakukan aktivitas apa saja secara baik yang sesuai dengan sifatnya.

Berdasarkan asumsi tentang adanya kesejajaran antara cara hidup atau tipe manusia dan tipe masyarakat, Socrates membedakan tipe manusia (jiwa manusia dan cara hidup) menjadi tiga, yaitu akal budi (reason), semangat (spirit), dan nafsu (desire). Ketiga bagian itu mencapai puncak kegiatannya apabila setiap bagian aktif secara penuh di bawah pengarahan akal budi. Lalu, keadilan akan terwujud dalam masyarakat apabila setiap individu (warga negara) melakukan secara baik apa saja yang sesuai dengan kemampuan dengan cara bekerja sama secara serasi diantara ketiga komponen tersebut. ketiganya di kontrol satu dengan lainnya untuk berfungsi secara keseimbangan, sehingga dapat memancarkan suatu nilai yang disebut 'kebijaksanaan'.

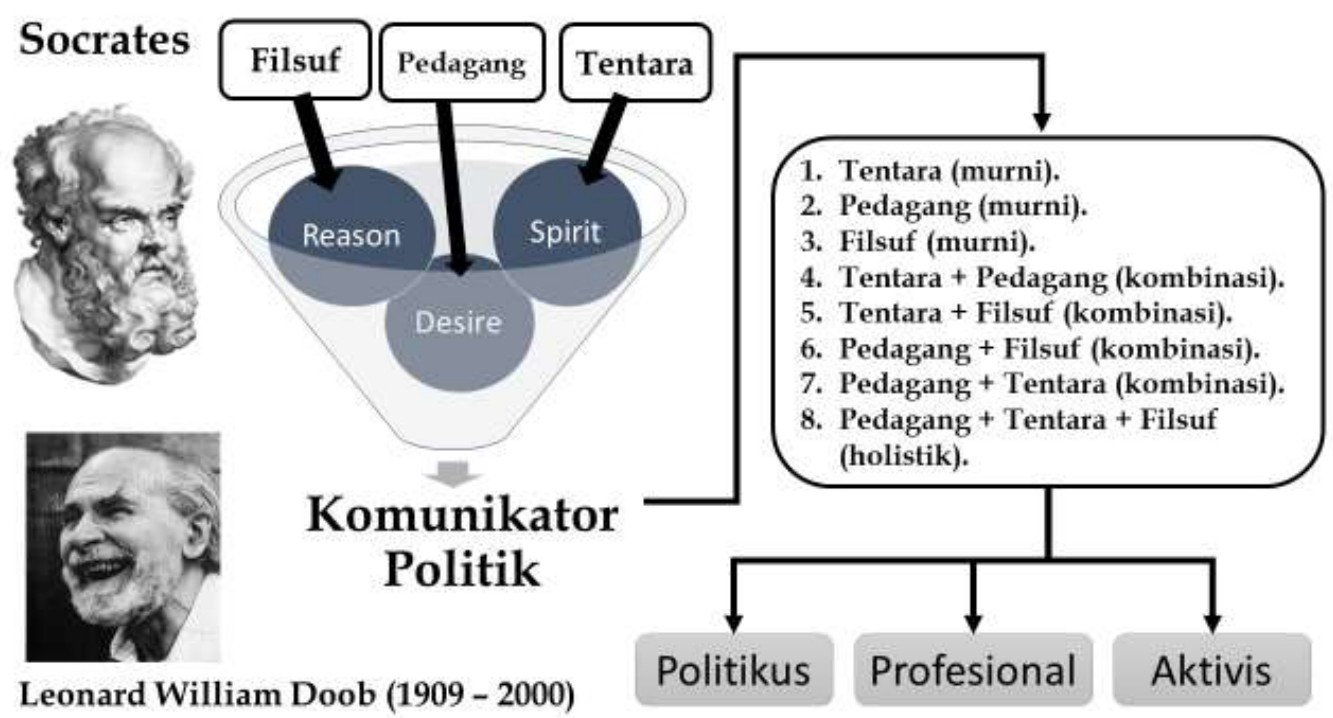

Gambar: 4.1: Komunikator Politik

Dari tiga tipe tersebut, Socrates membagi masyarakat menjadi tiga kelas. Pertama, pedagang yang bekerja mencari uang sebanyak-banyaknya (nafsu). Kedua, prajurit yang bekerja memelihara tata masyarakat (semangat). Ketiga, filsuf yang berfungsi sebagai penguasa (akal budi). Menurut Socrates, suatu rezim atau masyarakat dikatakan adil manakala setiap kelas melaksanakan fungsi dan pekerjaannya secara maksimal dan bekerja sama secara harmonis di bawah pengarahan raja/pemimpin filsuf yang bijaksana. Hal ini diperkuat dengan pernyataan Plato dimana Negara harus dikuasai oleh para ahli pikir atau filsuf, sosok yang menurutnya mengerti persoalan secara benar dan tahu mana yang baik dan buruk. Karakter filsuf adalah dimana nafsu duniawi sudah dikendalikan oleh hati nurani, sudah tidak ada lagi motif (nafsu) untuk berkuasa (tahta), motivasi mengumpulkan harta dan hawa nafsu dunia lainnya yang tidak akan pernah habis. Apa yang dilakukan 
oleh manusia yang sudah mencapai tahap filsuf adalah bagaimana menerapkan kebaikan dan kebenaran.

Kita bisa melihat bagaimana latarbelakang politikus yang akhirnya tercermin pada gaya kepemimpinan, gaya komunikasi dan orientasi kerjanya. Sukarno berlatar belakang seorang akademisi (insinyur) dan pernah ikut militer juga (tentara PETA), kemampuan berbicara sebagai orator ulung tidak diragukan dimana setiap pidatonya mampu membakar massa, begitu pula dengan SBY yang bergelar Doktor merupakan perpaduan militer dan akademisi. Suharto latar belakang militer murni tercermin dengan penerapan pemerintahan yang di dominasi peran militer walaupun terkenal dengan sebutan "The smilling general", Habibie adalah sipil dan ilmuan yang seorang teknokrat (pemikir), walaupun ilmuan tapi belum tentu menjadi seorang filsuf. Lalu ada yang berlatar belakang pengusaha (pedagang) seperti Yusuf kala dan Jokowi. Indonesia sudah sangat bervariasi dengan pernah munculnya sosok pemimpin dari kalangan 'ulama (ilmuan), yaitu Gus Dur dan juga keterwakilan perempuan Megawati yang mewarisi genetika politik dari ayahnya, sehingga komplit pengalaman berbagai karakter dan kepemimpinan dengan ciri khasnya masing-masing di Indonesia. Berbagai profesi akhirnya melebur masuk kepada kerangka kerja Politikus dimana harus berpikir secara makro terhadap masalah kenegaraan, kebangsaan dan kerakyatan secara menyeluruh. Selanjutnya ada juga yang menjadi profesional dan aktifis dimana ketiga peran ini merupakan komunikator politik.

Pertanyaannya adakah di era sekarang seorang Politikus ideal berkarakter seorang filsuf? Politikus yang seorang filsuf tidak berorientasi kepada harta dan tahta semata, tidak berlebih-lebihan, tidak mendapatkan fasilitas mewah dan hidup dengan gaya mewah yang dapat memicu kecemburuan sosial. Melihat Politikus yang memiliki harta benda milyaran bahkan triliyunan, biasanya hanya akan memenuhi ambisinya untuk berkuasa. Bila masih tahap pemula sebagai Politikus, bisa jadi ada motif lain yaitu merubah nasib agar menjadi orang kaya. Bila memang mengabdi untuk kepentingan rakyat, siapkah mereka mengorbankan kepentingan kesenangan pribadinya? Siapkah mereka untuk menahan diri (puasa) dari hidup mewah sementara permasalahan rakyat masih kompleks, kemiskinan, krisis moral, hingga banyak terjadi perbuatan kriminal, prostitusi, kekerasan fisik, seksual, verbal dan ekonomi merajalela? Nabi Muhammad mendidik bahwa pemimpin adalah orang yang pertama kali lapar dan terakhir kali kenyang. Khalifah Umar Ibnul Khaththab menolak memakan daging dan makanan lezat lainnya pada musim krisis yang menimpa warganya. Beliau hanya makan roti keras dan minyak goreng sehingga beliau menderita sakit perut lantaran ingin merasakan secara langsung penderitaan rakyatnya, seperti ungkapan beliau. "Bagaimana mungkin saya dikataka peduli pada penderitaan rakyat jika saya tidak merasakan apa yang mereka rasakan"6.

6 Adian Husaini, Penyesatan Opini: Sebuah Rekayasa Mengubah Citra, Jakarta: Gema Insani Press,2002, hlm. 38 
Bisa jadi apa yang dimaksud oleh Plato yaitu Politikus atau pemimpin yang seorang filsuf maksudnya adalah suatu tahapan yang terjadi pada seorang manusia dimana dia sudah memikirkan hakekat atau tujuan murni dari kehidupan ini. Mencapai tahapan ini bukan suatu proses yang instan, tapi pasti merupakan puncak kesadaran seseorang melihat kehidupannya sangat sungguh-sungguh (serius) untuk bemakna (nilai), berperan, dan bermanfaat bagi kehidupan, bagi sesama manusia dan alam semeseta. Ini merupakan fase mendekat kepada Sang Pencipta dalam perspektif berbeda hampir mirip dengan sufisme dalam Islam, perjalanan pulang menuju tempat dimana dia berawal. Fase ini membuat manusia jauh dari niat, pikiran untuk berbuat jahat, bermain-main terhadap kehidupan yang hanya sementara. Pengalaman dan umur yang sudah matang membuat seseorang yang sedang menuju tahap filsuf berkali-kali melakukan kesalahan dan berkali-kali mengevaluasi, menyadari, dan memperbaikinya. Sampai akhirnya tahap hanya ingin melakukan pengabdian dan meluruskan sesuatu yang salah atau membuat keseimbangan dalam kehidupan ini. Namun apa yang terjadi secara fakta (empiris), hampir sulit terjadi seorang yang sudah zuhud, penyerahan diri pada pengabdian kepada Ilahi mau terjun ke gelangang politik, mereka (filsuf/ sufi) lebih memilih mengasingkan diri dan fokus terhadap perenungan, membersihkan hatinya dan menyebarkannya untuk kebaikan, karena dunia politik kecendrungannya sangat bersifat duniawi dan penuh dengan tipu daya yang sangat bertentangan tujuan dari filsafat dan kesufian menuju kepada kebenaran yang hakiki. Kalaupun terjadi karena terdorong peristiwa yang sangat kronis atau extra ordinary.

Komunikator politik akan berada di dua kutub sistem politik, yaitu pertama, sub-sistem suprastruktur (the governmental political sphere) yang merupakan iklim kehidupan politik pemerintah, dan kedua, sub-sistem infrastruktur yang merupakan iklim kehidupan politik masyarakat (the socio political sphere). Kedua iklim tersebut adalah berlakunya proses sistem politik dimana keduanya saling mempengaruhi. Infrastruktur sebagai sosial kontrol yang juga dapat memberikan input (masukan) yang berpotensi memberikan masukan atau mempengaruhi kebijakan suprastruktur (output). Diantara kedua sub-sistem tersebut merupakan bentuk komunikasi model interaksional yang berciri khas adanya umpan balik. Masing-masing mempunyai daya respon yang terus mengalir satu sama lainnya, sehingga model komunikasi yang berlaku adalah model transaksional. Suprastruktur dan infrastruktur politik akan bertukar tempat dimana akan menjadi komukator (pengirim pesan) dan sekaligus secara bergantian menjadi komunikan (penerima pesan). Feedback akan terjadi di suatu negara dengan sistem demokrasi, dimana feedback bisa dalam bentuk hak untuk menyampaikan pendapat berupa saran, pendapat, masukan dan juga pemikiran dari unsur masyarakat (infrastruktur) dan akan sulit dilakukan di negara dengan sistem totaliter atau komunis. Umpan balik (feedback) dan respon (response) merupakan unsur komunikasi yang bermakna reaksi dari pesan yang dikirimkan. Namun, perbedaannya feedback merupakan reaksi 
umpan balik langsung dalam proses komunikasi dan responce adalah reaksi umpan balik tidak langsung dalam proses komunikasi. Jadi feedback merupakan indikator bahwa pesan yang dikirim ditanggapi dan berlanjut, juga dapat digunakan untuk membaca atau memahami kondisi audiens (komunikan) yang menjadi lawan bicaranya. Respons memerlukan waktu atau fase namun bersifat relatif, karena timbulnya respons merupakan stimulus dari media massa, media sosial dan yang paling berpengaruh kuat adalah adanya opinion leader (pemuka pendapat) atau tokoh masyarakat (infromal leader) dengan menggunakan kharisma atau kemampuan persuasi, retorika dan orasi kepada khalayak banyak dengan pesan-pesan komunikasi, sehingga reaksi masyarakat tergantung kepada tingkat kepentingan para pemuka pendapat. Seperti yang dijelaskan Wilbur Schramm ${ }^{7}$ dalam teori two step flow of communication, dimana komunikasi melalui media massa tidak langsung diterima masyarakat secara umum tapi harus melalui para pemuka pendapat. Feedback dan responce juga bisa dalam bentuk positif berupa dukungan dan masukan positif terhadap kebijakan penguasa dan negatif berupa menolak kebijakan yang dirasakan merugikan kepentingan masyarakat dalam bentuk protes atau demonstrasi. Umpan balik dapat dilakukan dengan menggunakan saluran tatacara yang sudah diatur oleh undang-undang, seperti zaman Orde Baru kita mengenal ada PO BOX 5000 dengan mengirimkan surat pengaduan ke alamat tersebut, dan di era digital saat ini respon dan umpan balik bisa disalurkan melalui media sosial, seperti Facebook, twitter, youtube dan sebagainya. Maka kedudukan komunikator politik seperti penjelasan diatas adalah sebagai berikut.

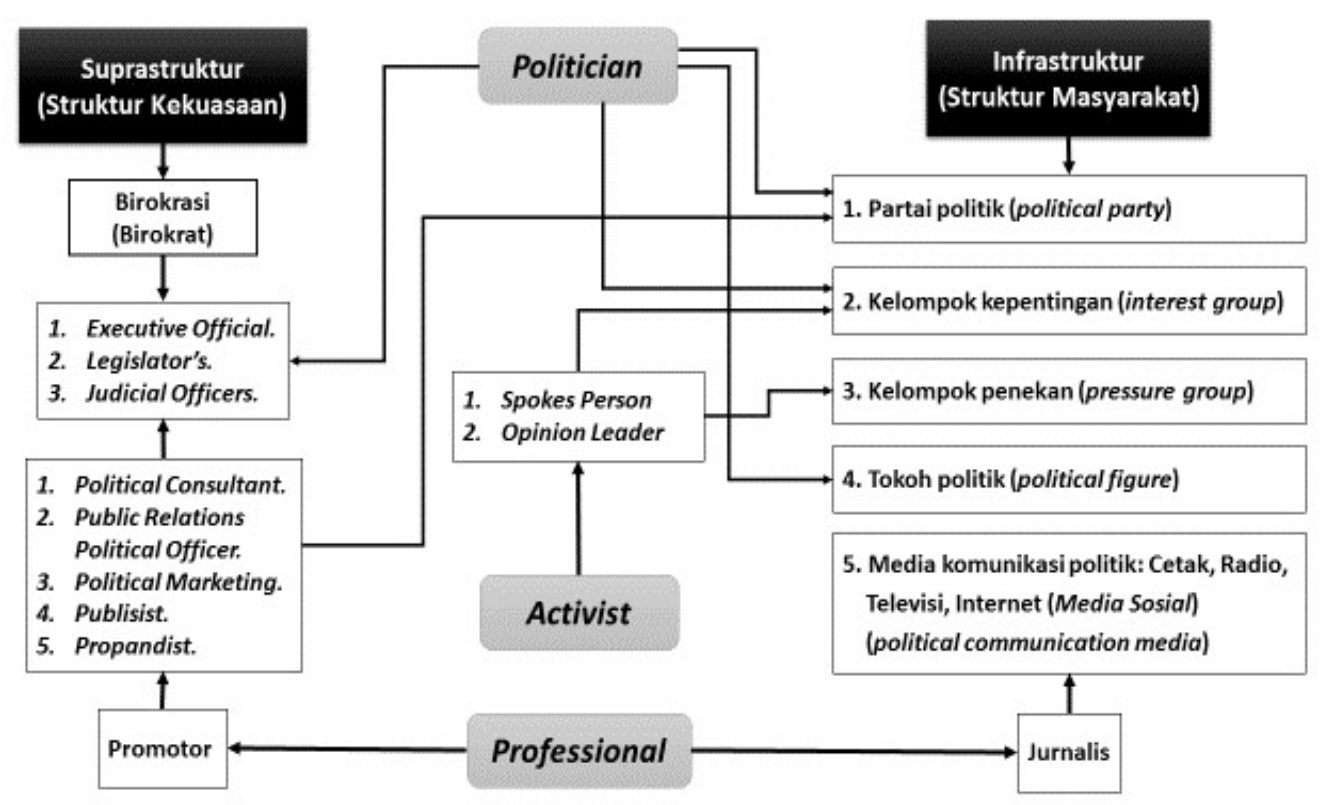

Gambar: 4.2: Komunikator Politik dalam Sistem Politik

\footnotetext{
${ }^{7}$ Soemarno, AP, Komunikasi Politik, Jakarta: Universitas Terbuka, 2009, hlm. 1.30
} 
Bila kita fahami dari gambar diatas, maka bisa kita pahami bahwa setiap komponen komunikator politik (politician, activist, professional) merupakan elite dari berbagai bidang. Pengertian kata elite berasal dari bahasa Latin (eligere) yang berarti 'memilih' dalam bahasa Indonesia kata elite berarti 'orang-orang terbaik atau pilihan dalam suatu kelompok' atau 'kelompok kecil orang-orang terpandang atau berderajat tinggi (kaum bangsawan, cendekiawan, dsb). ${ }^{8}$ Bisa dikatakan para elite tersebut merupakan individuindividu yang menduduki posisi puncak dalam institusi ekonomi, politik dan militer. Maka pernah kita dengar juga adanya pasukan elite atau pasukan khusus yang merupakan kumpulan dari tentara terpilih dari semua angkatan. Kalangan elite berasal dari berbagai elemen masyarakat itu dapat mencapai puncak kekuasaan karena mempunyai 'power' (kekuatan). Kekuatan itu bisa bersumber dari kekuatan uang, kekuatan intelektual, kekuatan berdasarkan kekeluargaan, bisa juga kekuatan kharismatik, popularitas, integritas dan spiritual. Komunikator politik adalah elite atau kumpulan kecil orang yang berkecimbung bidang politik, ada elite tingkat tinggi dan rendah sesuai lapisan struktur kekuasaannya.

\section{Politikus}

Politikus bisa dipastikan sebagai pemegang pemerintahan strategis. Bagi mereka pemerintah wajib dicapai bahkan mereka bisa melakukan segala cara untuk memenuhi tersebut. Berdasarkan uraian sebelumnya, bahwa tipe politikus bisa berasal dari kalangan pedagang (pengusaha), militer, atau dari kalangan pemikir yang dikatakan Socrates seorang filsuf atau bisa dikatakan seorang ilmuan (akademisi) dan bisa juga merupakan perpaduan diantaranya. Berdasarkan gambar 4.2 politikus akan tersebar di dua struktur politik, yaitu di suprastruktur dan infrastruktur. Suprastruktur adalah struktur kekuasaan yang pada dasarnya merupakan birokrasi, yaitu sistem pemerintahan dimana di dalamnya terdapat hierarki dan jenjang jabatan mulai dari pegawai pemerintah paling bawah sampai dengan pejabat tinggi (Birokrat). Para pegawai bekerja dengan tata aturan yang kompleks dan ketat sehingga terkesan menjadi lama dari sisi waktu karena harus mengikuti tahapan-tahapan prosedural. Dalam struktur birokrasi pemerintahan ada jabatan yang diperoleh melalui proses politik (pemilihan) yang disebut dengan jabatan politik seperti Presiden, Gubernur, dan Kepala Daerah dan ada yang diangkat atau dipilih memegang jabatan pemerintah berdasarkan kualifikasi tertentu (pejabat karier). Jabatan politik dibatasi dengan periode biasanya setiap 5 tahun sekali dan untuk jabatan karier memiliki masa jabatan sampai usia pensiun. Politikus tersebar di lembaga suprastrukur, yaitu: eksekutif, legislatif, atau yudikatif dan juga di infrastruktur seperti

\footnotetext{
${ }^{8}$ badanbahasa.kemdikbud.go.id, http://badanbahasa.kemdikbud.go.id/lamanbahasa/petunjuk_praktis/374, diakses 31 May 2016.
} 
pimpinan organisasi politik (Partai Politik), kelompok kepentingan, dan juga bisa dalam kalangan tokoh masyarakat.

Kelompok kepentingan adalah sekelompok manusia yang mengadakan persekutuan yang didorong oleh kepentingan-kepentingan tertentu. Kepentingan ini dapat berupa kepentingan umum atau masyarakat luas ataupun kepentingan untuk kelompok tertentu. Contoh persekutuan yang merupakan kelompok kepentingan, yaitu organisasi masyarakat (KOSGORO, NU, Muhammadiyah), kelompok cendikiawan atau pakar di berbagai bidang ilmu pengetahuan, paguyuban daerah, alumni, kelompok daerah asal, organisasi mahasiswa, organisasi pemuda (KNPI, Pemuda Pancasila), organisasi profesi (AIPI, IDI, ISKI, ISEI), paguyuban hobi tertentu, dan sebagainya. ${ }^{9}$ Kelompok kepentingan bertujuan untuk memperjuangkan sesuatu 'kepentingan' dengan mempengaruhi lembaga-lembaga politik agar mendapatkan keputusan yang menguntungkan atau menghindari keputusan yang merugikan. Kelompok kepentingan tidak berusaha untuk menempatkan wakil-wakilnya dalam dewan perwakilan rakyat, melainkan cukup mempengaruhi satu atau beberapa partai didalamnya atau instansi yang berwenang maupun menteri yang berwenang. ${ }^{10}$ Namun, dalam kenyataannya terkadang kelompok kepentingan bisa juga dijadikan batu loncatan atau jembatan bagi politikus infrastruktur yang bisa jadi tokohtokoh Parpol, Ormas dan komunitas yang berpengaruh di masyarakat untuk masuk ke suprastruktur politik, ada yang ikut dalam pemilihan atau diangkat untuk memegang jabatan di lembaga eksekutif, bisa sebagai mentri, kepala Dirjen, diplomat, komisaris di BUMN, dan sebagainya. Dengan masuknya ke dalam suprastruktur politik maka kelompok kepentingan dapat lebih maksimal mengimplementasikan kepentingan, ide dan gagasannya. Ada kegiatan-kegiatan para komunikator politik yang melibatkan kelompok kepentingan untuk meminta masukan, rekomendasi, pertimbangan dan juga kritik terhadap program dan kebijakan penguasa (komunikator politik). Dalam kondisi tertentu kelompok kepentingan juga bisa bertransformasi menjadi kelompok penekan bila memang ada suatu ketidakadilan, kesewenang-wenangan dari penguasa yang tidak berhasil diselesaikan melalui jalan musyawarah dan mufakat.

Daniel Katz ${ }^{11}$ membedakan politikus ke dalam dua hal yang berbeda berkenaan dengan orientasi kepentingan politikus pada proses politik yaitu: politikus ideolog (negarawan); serta politikus partisan.

a. Politikus ideolog adalah orang-orang yang dalam proses politik lebih memperjuangkan kepentingan bersama (publik). Mereka tidak begitu terpusat perhatiannya kepada mendesakkan tuntutan pengikut atau kelompoknya. Mereka lebih menyibukkan dirinya untuk menetapkan tujuan kebijakan yang lebih luas, mengusahakan reformasi, bahkan

\footnotetext{
${ }^{9}$ Bambang S dan Sugianto,Pendidikan Kewarganegaraan, Surakarta:Penerbit Grahadi,2007, hlm. 176

${ }^{10}$ Eddi Wibowo dkk, Ilmu Politik Kontemporer, Yogyakarta:YPAPI,2004, hlm. 69

${ }^{11}$ Nimmo, OP, Cit, hlm. 31
} 
mendukung perubahan revolusioner, jika hal ini mendatangkan kebaikan lebih bagi bangsa dan negara. Ideolog berargumen dengan menawarkan gagasan yang lebih baik, menyakinkan orang kepada satu cara berpikir (menyatukan visi).

b. Politikus wakil (partisan) adalah orang-orang yang dalam proses politik lebih memperjuangan kepentingan pengikut atau kelompoknya. Wakil sebagai makelar yang membujuk orang lain agar ikut dan setuju dengan gagasan mereka.

Dengan demikian, politikus utama yang bertindak sebagai komunikator politik yang menentukan dalam pemerintah tingkat nasional maupun tingkat daerah, seperti para pejabat eksekutif (presiden, menteri, gubernur, bupati, walikota, kecamatan, kelurahan,); para pejabat legislatif (ketua MPR, Ketua DPR/DPD/ DPRD I, DPRD II, Ketua Fraksi, Anggota DPR/DPD/ DPRD I, DPRD II) dan otomatis dengan para wakilnya dan anggotanya; para pejabat yudikatif (Ketua/anggota Mahkamah Agung, Ketua/anggota Mahkamah Konstitusi, Jaksa Agung, jaksa), di Indonesia jabatan publik pejabat Yudikatif adalah jabatan yang diangkat oleh Presiden dengan persetujuan Parlemen (DPR) sehingga kepentingan politik bisa mengintervensi dalam keputusannya. Seharusnya pejabat di lembaga Yudikatif bebas kepentingan (independent) atau bebas dari intervensi politik, karena dilembaga inilah keadilan ditegakkan. Pada saat adanya konflik, pertikaian dan sengketa, lembaga Yudikatif adalah muara terakhir penyelesaiannya. Begitu pula suprastruktur melahirkan lembaga-lembaga netral dan independen (untuk kepentingan publik) lainnya yang bertugas atau mengawasi baik secara interal suprastuktur (kekuasaan) dan juga infrastruktur politik (masyarakat), seperti Kepolisian, Komisi Pemilihan Umum (KPU), Komisi Pemberantasan Korupsi (KPK), Komisi Penyiaran Indonesia (KPI), Komisi Informasi Publik (KIP), Komisi Yudisial (KY), Kompolnas, dan lain-lain. Mereka adalah lembaga yang petugasnya disebut sebagai komisaris (Kepolisian) atau komisioner yang ketuanya merupakan jabatan publik diangkat oleh presiden berdasarkan pertimbangan DPR. Terkadang pengangkatan dan pemberhentian jabatan ketua komisioner menjadi pertarungan diantara kepentingan politik.

\section{Profesional}

Menurut kamus Meriam Webster, professional adalah: "relating to a job that requires special education, training, or skill; done or given by a person who works in a particular profession; paid to participate in a sport or activity".12 Jadi profesional adalah suatu yang berkaitan dengan pekerjaan dan memerlukan pendidikan khusus, pelatihan, atau keterampilan. Dilakukan atau diberikan

${ }^{12}$ merriam-webster.com, http://www.merriam-webster.com/dictionary/professional, diakses 31 Mei 2016. 
oleh seseorang yang bekerja di profesi tertentu dalam hal ini dibidang yang berkaitan dengan dunia politik. Lalu profesi orang tersebut dibayar untuk berpartisipasi dalam suatu kegiatan, seperti dalam dunia olahraga, contoh pemain sepak bola profesional dikontrak dengan bayaran yang cukup besar agar fokus terhadap pekerjaannya, jadi tidak ada pekerjaan sampingan yang akan memecah konsentrasi terkait tugas dan tanggung jawabnya. Dan $\mathrm{Nimmo}^{13}$ menyebutkan pengertian profesional adalah orang-orang yang mencari nafkahnya dengan berkomunikasi, di dalam atau di luar politik. Munculnya komunikator profesional dalam dunia politik adalah karena kemajuan teknologi baru dibidang media massa, multimedia dan media baru.

Bisa disimpulkan profesional adalah berkaitan dengan keahlian dan keterampilan khusus yang dibutuhkan oleh yang memperkerjakannya dan dia sangat menguasai bahkan sangat fokus dengan perkerjaannya. Sehingga penyandangan dan penampilan 'professional' ini telah mendapat pengakuan, baik secara formal maupun informal. Tentunya keahlian dan keterampilannya akan mendapatkan kopensasi yang setimpal berupa upah atau gaji. Nah, yang menjadi pertanyaan adakah kaitannya antara melakukan tugas atau pekerjaannya dengan pengabdian dalam dunia politik? Apakah bila dia tidak diupah dengan nominal yang sesuai atau rendah, dia akan tetap melakukan pekerjaannya? Ini bisa dikatakan hubungan yang profesional, dalam arti mungkin ada batasan (masa kontrak), dan profesional tidak terikat dengan suatu ideologi ataupun masalah personal. Kecuali dalam perjalanannya terjadi dinamika berkaitan status profesional yang berubah menjadi politikus, karena dunia politik murni yang dinamis (baca: kepentingan).

Berdasarkan gambar 4.2 ada diagram yang menunjukan dua kutub yang berbeda berkatian dengan komunikator politik profesional. Arah panah pertama menuju suprastruktur politik (promotor) dan yang arah panah kedua menuju ke infrastruktur politik (jurnalis). James Carey ${ }^{14}$ mengatakan bahwa komunikator profesional adalah makelar simbol, yaitu orang yang menerjemahkan sikap, pengetahuan, dan minat suatu komunitas bahasa yang satu ke dalam istilah-istilah komunitas bahasa yang lain yang berbeda tetapi menarik dan dapat dimengerti. Komunikator profesional beroperasi (menjalankan kegiatannya) di bawah desakan atau tuntutan yang di satu pihak oleh khalayak akhir dan di lain pihak oleh sumber komunikasi. Bagi profesional, profesinya adalah komunikasi, bukan bidang politik praktis. Jadi biasanya profesional akan berkerja atau menyukseskan orang atau institusi baik politik dan non politik yang membayarnya. Bila tidak dibayar secara profesional maka dia akan mencara pelanggan baru yang akan menyewa jasanya.

\footnotetext{
${ }^{13}$ Nimmo, OP, Cit, hlm. 33

${ }^{14}$ Nimmo, OP, Cit, hlm. 33
} 


\section{a. Jurnalis}

Jurnalis adalah siapapun yang berkaitan dengan media berita dalam pengumpulan, persiapan, penyajian, dan penyerahan laporan mengenai peristiwa-peristiwa. Ini meliputi reporter yang bekerja pada koran, majalah, radio, televisi, atau media lain; koordinator berita televisi; penerbit; pengarah berita; eksekutif stasiun atau jaringan televisi dan radio; dan sebagainya. Sebagai komunikator profesional, jurnalis secara khas adalah karyawan organisasi berita yang menghubungkan sumber berita dengan khalayak.

Mereka bisa mengatur para politikus untuk berbicara satu sama lain, menghubungkan politikus dengan publik umum, menghubungkan publik umum dengan para pemimpin, dan membantu menempatkan masalah dan peristiwa pada agenda diskusi publik. Lalu bagaimana bila profesi tersebut dibawah media yang pemiliknya (owner) terjun di politik atau ketua Parpol dan juga bilamana ada jurnalis yang dibayar untuk membuat berita atau men-setting berita untuk kepentingan pihak ketiga. Media massa sebagai pilar keempat (4) demokrasi seharusnya bebas kepentingan, netral dan independen. Maka jurnalis tidak boleh menerima bayaran dari sumber berita agar tetap pada idealisme yang tidak memihak, kecuali kepada fakta.

\section{b. Promotor}

Dalam kamus besar bahasa Indonesia (KBBI), promotor adalah orang yang menjadi penganjur atau pendorong suatu usaha (gerakan dan sebagainya). ${ }^{15}$ Dan Nimmo mengatakan promotor adalah orang yang dibayar untuk mengajukan kepentingan langganan tertentu. ${ }^{16}$ Jadi promotor adalah orang yang dibayar untuk mempromosikan (publisitas) kandidat atau partai politik seperti marketing politik, menyelengarakan acara seperti kampanye saat pemilu, atau sebagai Public Relation Politik yang bekerja untuk menjaga citra dan reputasi kandidat atau institusi, hubungan masyarakat (Humas) pemerintahan yang menjaga dan mengatur pengelolaan komunikasi baik secara internal dan eksternal pemerintahan, pejabat informasi publik pada jawatan pemerintah, sekretaris pers kepresidenan, personal periklanan perusahaan, manajer kampanye dan pengarah publisitas kandidat politik, spesialis teknis seperti kameramen, produser dan sutradara film, pelatih pidato, konsultan politik, dan semua jenis makelar simbol yang sejenis.

Sehingga promotor memang tidak netral karena profesionalismenya yang menjual keahliannya untuk memanipulasi, menjual, menghubungkan, dan menginterpretasikan kepada politikus dan khalayak. Contoh konsultan politik melakukan riset untuk mengetahui prefernsi masyarakat terhadap partai politik, maka hasil riset hanyalah untuk kandidat penyewanya bukan dipublikasikan ke masyarakat umum. Kecuali lembaga riset yang independen seperti Lembaga Survei Indonesia (LSI), Indo Barometer dan lainnya, justru

\footnotetext{
${ }^{15}$ kbbi.web.id, http://kbbi.web.id/promotor, diakses 31 May 2016.

${ }^{16}$ Nimmo, OP, Cit, hlm. 35
} 
mereka wajib mempublikasikan hasil risetnya sebagai pengetahuan bagi masyarakat. Termasuk pengamat politik yang bisa jadi dibayar untuk mengeluarkan statement (argumentasi) untuk kepentingan yang menyewa jasanya. Sebagian promotor menjalankan pekerjaanya tanpa memperhatikan baik suka ataupun tidak suka kepada penyewanya dan juga kepada khalayak umum. Kewajiban utama promotor adalah mendukung kepentingan langganan (penyewa) untuk mencapai tujuannya, daripada mengungkap fakta atau informasi sebenarnya yang mungkin akan merugikan pelanggannya.

\section{Aktivis}

Ada beragam definisi aktivis seperti yang dikutip di Kamus Besar Bahasa Indonesia (KBBI), aktivis (ak ti vis) $\mathrm{n} 1$. orang (terutama anggota organisasi politik, sosial, buruh, petani, pemuda, mahasiswa, wanita) yang bekerja aktif mendorong pelaksanaan sesuatu atau berbagai kegiatan dalam organisasinya; 2. (Politik) seseorang yang menggerakkan (demonstrasi dan sebagainya). ${ }^{17}$ Lalu badan bahasa di Kementrian Pendidikan dan Budaya (Kemdikbud $)^{18}$ mendefinisikan aktivis adalah orang yang giat bekerja untuk kepentingan suatu organisasi politik atau organisasi massa lain. Dia mengabdikan tenaga dan pikirannya, bahkan seringkali mengorbankan harta bendanya untuk mewujudkan cita-cita organisasi. Contoh kalimat yang menggunakan kata aktivis adalah sebagai berikut. 1. Beberapa aktivis lembaga sosial masyarakat mengingatkan pentingnya lingkungan hidup yang sehat. 2. Organisasi kita memerlukan seorang aktivis yang rela menyumbangkan tenaga dan pikirannya untuk kelangsungan hidup organisasi. Begitu pula definisi aktivis pada vocabulary.com, ${ }^{19}$

"An activist is a person who campaigns for some kind of social change. When you participate in a march protesting the closing of a neighborhood library, you're an activist. Someone who's actively involved in a protest or a political or social cause can be called an activist. Demonstrations, strikes, and sit-ins are all ways that an activist might work toward the change she believes in. The root word of activist is the Latin actus, "a doing, a driving force, or an impulse." Someone who acts on what they believe is an activist".

Jadi seorang aktivis adalah orang yang mengkampanyekan dalam rangka suatu perubahan sosial. Seorang aktivis juga bisa dalam bentuk partisipasi dalam aksi turun kejalan untuk melakukan aksi memprotes,

\footnotetext{
${ }^{17}$ kbbi.web.id, http://kbbi.web.id/aktivis, diakses 1 Juni 2016.

18 badanbahasa.kemdikbud.go.id,

http://badanbahasa.kemdikbud.go.id/lamanbahasa/petunjuk_praktis/182, diakses 1 Juni 2016

${ }^{19}$ vocabulary.com, https://www.vocabulary.com/dictionary/activist, diakses 1 Juni 2016.
} 
misalnya yang berkaitan dengan fasilitas umum seperi yang dicontohkan definisi diatas adalah protes terhadap penutupan perpustakaan di lingkungan sosial oleh sebuah kebijakan penguasa atau pemerintah. Seseorang yang secara aktif terlibat dalam protes terhadap masalah kebijakan politik atau sosial bisa juga disebut seorang aktivis. Demonstrasi, pemogokan, dan pendudukan atau pemblokiran adalah cara-cara yang seorang aktivis berkerja untuk ke arah perubahan, karena aktivis adalah kelompok penekan (presure group) yang dalam kondisi tertentu akan dilakukan bila tidak ada respon positif dari penguasa atau pihak yang berwenang. Akar kata aktivis adalah dari bahasa Latin, yaitu 'actus', yang berarti sebuah gerakan (a doing), kekuatan pendorong (a driving force), atau suatu dorongan (an impulse)." Aktivis adalah seseorang yang bekerja dan memperjuangkan pada apa yang dia percaya.

Berdasarkan beberapa definisi yang sudah dipaparkan sebelumnya, aktivis sebagai komunikator politik utama sebagai saluran organisasional dan interpersonal. aktivis adalah seseorang yang memperjuangkan suatu misi perubahan sosial dengan kesadaran diri yang tinggi tanpa ada paksaan atau tekanan dari pihak manapun. Mereka menginginkan perubahan sosial atau gerakan penyeimbang yang ingin meluruskan, memperbaiki dari kondisi ketidakadilan dan ketidakseimbangan di dalam suatu sistem politik. Mereka bergerak diluar kekuasaan dan melawan kesewenang-wenangan penguasa. Keberadaan aktivis bisa menjadi kontrol sosial terhadap pemerintah. Maka mereka cenderung berada diluar kekuasaan. Tapi, lagi-lagi tidak ada gading yang tak retak, aksi sosial aktivis ada potensi juga di intervesi dari politikus atau partai politik yang menjadikannya sebagai jembatan atau corong komunikasi kepada masyarakat bawah (akar rumput) demi kepentingan politiknya. Bisa dalam bentuk aksi-aksi sosial, seperti di daerah bencana, kerja bakti dan aksi sosial lainnya.

Selain aktivis ada juga istilah relawan, sukarelawan atau volunteer. Dalam buku ini memang sengaja ditekankan makna yang terkandung dari istilah-istilah yang ada (terminologi), agar tidak terjadi pemahaman yang ambigu dalam perspektif masing-masing yang bersifat subyektif. Maka memang ada pengutipan dari kamus yang baku, baik dari Indonesia atau luar negeri sebagai pembandingnya. Relawan adalah orang yang tanpa dibayar menyediakan waktunya untuk mencapai tujuan organisasi, dengan tanggung-jawab yang besar atau terbatas, tanpa atau dengan sedikit latihan khusus, tetapi dapat pula dengan latihan yang sangat intensif dalam bidang tertentu, untuk bekerja sukarela membantu tenaga profesional. ${ }^{20}$ Namun penggunaan kata 'relawan' menurut Badan Bahasa Kemendikbud tidak tepat , kata 'sukarelawan' mengandung pengertian orang yang dengan sukacita melakukan sesuatu tanpa rasa terpaksa. Kata sukarela ini berasal dari kata dasar sukarela dan imbuhan -wan. Dalam Kamus Besar Bahasa Indonesia21

\footnotetext{
${ }^{20}$ kbbi.web.id, http://kbbi.web.id/relawan, diakses 1 Juni 2016.

${ }^{21}$ badanbahasa.kemdikbud.go.id, http://badanbahasa.kemdikbud.go.id/lamanbahasa/petunjuk praktis/635, diakses 1 Juni 2016.
} 
pun, bentuk kata yang ada adalah sukarelawan, sedangkan kata relawan tidak ada. Oleh karena itu, kata yang sebaiknya kita gunakan adalah sukarelawan, bukan relawan. Kalau relawan berasal dari kata 'rela', ada kesan pasrah dan terpaksa, berbeda dengan istilah sukarelawan yang berdasarkan rasa suka, hobi dan cinta, sehingga bila berdasarkan rasa cinta maka akan rela berkorban dan konsisten (istiqamah) tanpa batasannya kecuali maut menjemput. Lalu istilah volunteer menurut dictionary.com ${ }^{22}$,

"(1) a person who voluntarily offers himself or herself for a service or undertaking. (2) a person who performs a service willingly and without pay. (3) Military. a person who enters the service voluntarily rather than through conscription or draft, especially for special or temporary service rather than as a member of the regular or permanent army."

Volunteer atau relawan adalah orang yang secara sukarela menawarkan dirinya untuk layanan atau usaha. Mereka juga melakukan layanan atau pengabdian dengan suatu kerelaan dan tanpa dibayar. Seperti yang dicontohkan pada definsi diatas dalam bidang militer, relawan adalahorang yang memasuki kegiatan atau partisipasi dengan sukarela bukan karena wajib militer atau karena ada kewajiban sehinga perserta merasa wajib melakukannya, terutama untuk pengabdian yang bersifat sementara dan bukan sebagai anggota tentara reguler atau permanen. Kegiatan atau aktivitas para aktivis dan relawan sebagai komunikator politik, biasanya secara individu dilakukan sebagai kegiatan paruh waktu (part time), karena mereka melakukannya bukan karena uang atau mencari nafkah. Mereka mempunyai pekerjaan utama untuk memenuhi kebutuhan hidupnya, sehingga para aktivis mempunyai jiwa yang merdeka mengekspresikan ide dan gagasannya, tidak terbelenggu oleh suatu kepentingan. Aktivis murni adalah yang memperjuangkan suatu ide atau gagasan dan bekerja semata-mata pengabdian, secara spiritual bisa merupakan panggilan jiwa untuk mengabdi kepada Tuhan yang diimplementasikan dalam bentuk kegiatan memperjuangkan keadilan dan kebenaran. Merujuk perjuangan Nabi dan Rasul menggambarkan suatu kemurnian niat dan tujuan seperti yang tertulis di Kitab Suci di bawah ini.

Katakanlah: "Aku tidak meminta upah sedikit pun kepada kamu dalam menyampaikan risalah itu, melainkan (mengharap kepatuhan) orang-orang yang mau mengambil jalan kepada Rabbnya." 23

"Dan kamu sekali-kali tidak meminta upah kepada mereka (terhadap seruanmu ini), itu tidak lain hanyalah pengajaran bagi semesta alam."24

\footnotetext{
${ }^{22}$ dictionary.com , http://www.dictionary.com/browse/volunteer , diakses 1 Juni 2016.

${ }^{23}$ Qs:Al-Furqaan, 25 ayaat 57 (terjemahan Departemen Agama RI).

${ }^{24}$ Qs:Yusuf, 12 ayaat 104 (terjemahan Departemen Agara RI).
} 
Namun, bisa jadi ada juga aktivis yang niat dan tujuannya memang karena dibentuk atau digerakkan oleh kekuatan politik tertentu, bahkan bisa jadi kekuatan luar negeri yang mempunyai misi tertentu yang semuanya itu terjadi dibelakang layar (misi rahasia atau terselubung). Semua peran ini akan terungkap seiring waktu berjalan, pada saat menghadapi sebuah ujian mengatasi berbagai masalah, konflik (kemanusiaan) dan bencana (situasi lingkungan alam yang tidak terprediksi). Apakah konsisten dengan sikap atau komitmennya. Bila memang para aktivis itu adalah dari kalangan yang oportunis, maka pada saat mendapatkan tekanan yang berat ${ }^{25}$ akan mundur atau bila dapat uang suap akan luntur dan kendur dalam memperjuangkan idealismenya, seperti seringnya kita lihat kasus-kasus penyuapan yang melibatkan Politikus dan aktivis agar bungkam terhadap isu tertentu. Kegiatan para aktivis akan mempunyai kekuatan bila terlembaga dengan pengelolaan yang baik. Perbedaan antara aktivis dan relawan adalah bila aktivis bergerak mandiri (independent) sedangkan relawan (baca: Sukarelawan) adalah suatu gerakan yang menginduk pada sebuah institusi atau individu yang sedang berupaya mencari dukungan atau pengaruh masyarakat. Para relawan atau sukarelawan, apakah murni karena kerelaannya (keikhlasannya), atau karena dibayar? Itu akan menjadi peran yang berbeda dalam aktivitasnya sebagai komunikator politik.

Pada saat kampanye pemilu banyak sekali bermunculan relawan, mulai dari relawan yang dibawah partai politik sampai relawan kandidat secara individu seperti pada Pemilihan Legislatif (Pileg) atau Pemilihan Presiden (Pilpres). Pada saat Pilpres kita sering mendengar relawan Jokowi (Relawan Salam Dua Jari, Relawan Kawan Jokowi, Relawan Projo, dan lainlain)26, relawan Prabowo-Hatta, dan menjelang Pemilihan Gubernur (Pilgub) DKI Jakarta 2017, munculnya "Teman Ahok" yang tampil dengan mengumpulkan 1 juta KTP untuk Ahok (Basuki Tjahaya Purnama) untuk maju sebagai Calon Gubernur melalui jalur independen. Fenomena relawan yang juga aktivis bila mau mengaktualisasikan perannya harus masuk ke struktur atau sistem politik. Bila mereka cukup menjadi pengawas penguasa mereka akan tetap di posisi infrastruktur politik, tapi bila ingin berperan lebih konkrit maka harus masuk ke suprastruktur politik. Pasca terpilihnya Jokowi-JK dapat kita lihat beberapa relawan yang membantu, mengkampanyekan salam dua jari (simbol kampanye Jokowi-Jk) sudah duduk di jabatan strategis pemerintahan. ${ }^{27}$

\footnotetext{
${ }^{25}$ Contoh yang kongkrit adalah bila ada ancaman dari penguasa, kondisi krisis keuangan, masalah personal dan keluarga, dan lain-lain.

26 Merdeka.com (23 Agustus 2014), Buka Rakornas II Projo, Jokowi minta relawan tidak bubar, http://www.merdeka.com/foto/peristiwa/buka-rakornas-ii-projo-jokowi-minta-relawan-tidakbubar.html, diakses 3 Juni 2016, jam 11.26

${ }^{27}$ nasional.kompas.com (12 April 2015), 16 Politikus dan Relawan Jokowi Jadi Komisaris, Bahaya Menanti BUMN,

http://nasional.kompas.com/read/2015/04/12/11412621/16.Politikus.dan.Relawan.Jokowi.Jadi.Komi saris.Bahaya.Menanti.BUMN, diakses 3 Juni 2016, jam 11.09
} 
Dan Nimmo ${ }^{28}$ mengatakan ada dua tipe komunikator politik aktivis yang bergerak melalui saluran organisasional dan interpersonal, yaitu: Jurubicara (spoke person) dan pemuka pendapat (opinion leader). Pertama, terdapat jurubicara bagi kepentingan yang terorganisasi. Pada umumnya orang ini tidak memegang ataupun mencita-citakan jabatan pada pemerintah; dalam hal ini komunikator tersebut tidak seperti politikus yang membuat politik menjadi lapangan kerjanya. Jurubicara ini biasanya juga bukan profesional dalam komunikasi, namun ia cukup terlibat baik dalam politik dan semi-profesional dalam komunikasi politik. Berbicara untuk kepentingan yang terorganisasi merupakan peran yang serupa dengan peran politikus wakil partisan, yakni mewakili tuntutan keanggotaan suatu organisasi dan tawar-menawar (lobbyist) demi mendapatkan hasil yang menguntungkan anggota yang diwakilinya atau setidaknya terjadi win-win solution. Jurubicara juga berperan sama seperti halnya jurnalis, yakni melaporkan keputusan dan kebijakan pemerintah kepada anggota suatu organisasi. Contoh pada saat adanya protes supir taksi kepada pemerintah terkait maraknya angkutan umum online, muncullah sosok Jurubicara Paguyuban Pengemudi Angkutan Darat (PPAD) yang bernama Miskun ${ }^{29}$, dia mewakili anggota PPAD untuk menyampaikan aspirasinya kepada pemerintah dan sebagai jurubicara kepada media massa. Karena bila tidak ada jurubicara yang akan terjadi adalah konflik antar kelompok yang tidak terkontrol sehingga berpotensi menjadi anarkis. Sama halnya pada saat terjadi konflik antara dua kubu Koalisi di Parlemen, Koalisi Merah Putih (KMP) dan Koalisi Indonesia Hebat $(\mathrm{KIH})$, ada momentum dimana ketegangan keduanya diselesaikan dengan mempertemukan jurubicara (juru runding) yang mewakili kedua kubu. Apa yang dilakukan adalah melakukan adalah negosiasi untuk membuat kesepatan penyelesaian konflik. Disamping jurubicara dalam gerakan aktivis sebenarnya tetap ada hierarki struktur sebagai jaringan komunikasinya, seperti ada otak intelektualnya, kordinator lapangan, bagian logistik, hubungan masyarakat yang berhubungan dengan pihak-pihak tertentu yang terkait, seperti perizinan untuk melakukan aksi demonstrasi, dan juga bisa jadi ada sponsor yang memberikan dukungan dana, dan sebagainya. Bila terjadi gerakan anarkis pihak yang berwenang biasanya mencari siapa "provokator" yang bertanggung jawab.

Kedua, terdapat pemuka pendapat yang bergerak dalam jaringan interpersonal. Sebuah badan penelitian ${ }^{30}$ yang besar menunjukkan bahwa banyak warga negara yang dihadapkan pada pembuatan keputusan yang bersifat politis, meminta petunjuk dari orang-orang yang dihormati mereka. Apakah untuk mengetahui apa yang harus dilakukannya atau memperkuat putusan yang telah dibuatnya. Orang yang dimintai petunjuk dan

\footnotetext{
${ }^{28}$ Nimmo, OP, Cit, hlm. 36-37

${ }^{29}$ jpnn.com (22 Maret 2016), Taksi vs Ojek Online, Jubir Demo: Mereka Jual Kami Beli, http://www.jpnn.com/read/2016/03/22/365176/Taksi-vs-Ojek-Online-Jubir-Demo:-Mereka-JualKami-Beli-, diakses 4 Juni 2016, jam 10.00

${ }^{30}$ Nimmo, OP, Cit, hlm. 37
} 
informasinya itu adalah pemuka pendapat (Opinion Leader). Mereka tampil dalam dua bidang. Pertama, Mereka sangat mempengaruhi keputusan orang lain; artinya, seperti politikus ideologis dan promotor profesional, mereka meyakinkan orang lain kepada cara berpikir mereka. Kedua, mereka yang meneruskan informasi politik dari media berita kepada masyarakat umum. Dalam arus komunikasi dua tahap gagasan sering mengalir dari media massa kepada pemuka pendapat dan dari mereka kepada bagian penduduk yang kurang aktif. Banyak studi yang membenarkan pentingnya kepemimpinan pendapat melalui komunikasi interpersonal sebagai alat untuk mengetahui peristiwa-peristiwa yang penting. Pemuka pendapat (opinion leader) pada kenyataan belum tentu juga seorang aktivis murni. Hal ini disebabkan bila ada permufakatan politik yang dibelakang layar pada saat partai politik mendekati tokoh-tokoh organisasi masyarakat terutama yang mempunyai pengaruh kuat ke akar rumput (grass root).

Berdasarkan gambar 4.2 terlihat bahwa aktivis murni akan berada di infrastrukur politik. Mereka bisa berada di kelompok kepentingan (interest group) dan kelompok penekan (pressure group). Pemahaman aktivis dan relawan ada perbedaan secara praktisnya, aktivis lebih aktif dan agresif sedangkan relawan biasanya sebagai gerakan sayap dari sebuah kekuatan bisa organsiasi masa atau sayap dari gerakan politikus yang berada di Partai politik atau kandidat yang diusung parpol atau independen. Tapi aktivis lebih cenderung kepada kelompok penekan, seperti: lembaga swadaya masyarakat (LSM) atau istilah lainnya Non Goverment Organisation (NGO), organisasi sosial keagamaan, organisasi kepemudaan, organisasi lingkungan hidup, organisasi pembela hukum dan ham, yayasan atau badan hukum lainnya. Sementara kelompok kepentingan menurut Gabriel A. Almond ${ }^{31}$ terdiri dari:

a. Kelompok anomik, yaitu kelompok spontan dan tidak memiliki nilai atau norma seperti melakukan kegiatan-kegiatannya dengan cara-cara yang non-konvensional; seperti pemogokan, demontrasi, huru-hara, kerusuhan, konfrontasi, dan lain-lainnya;

b. Kelompok Non asosiasional, biasanya jarang terorganisir dan kegiatannya kadang-kadang, berdasarkan atas kepentingankepentingan yang serupa karena persamaan-persamaan dalam hal-hal yang tertentu; seperti keluarga, status, kelas, kedaerahan, keagamaan, keturunan atau ethnis. Pendukung-pendukung kelompok kepentingan non assosiasional ini dalam mengartikulasikan kepentingan-kepentingannya melalui individu-individu, klik-klik, pemuka-pemuka agama, dan lain-lain yang semacam dengan itu. Kegiatan- kegiatan kelompok kepentingan non assosiasional terutama sekali berlangsung pada masyarakat yang belum begitu maju. Jadi dapat dinyatakan bahwa kelompok kepentingan non assosiasional

${ }^{31}$ Surbakti, OP, Cit, hlm. 141-142 
merupakan ciri bagian masyarakat yang belum begitu maju atau masyarakat yang sedang berkembang. Kelompok-kelompok kepentingan tipe ini terutama sekali memainkan peran dalam masyarakat yang agraris, walaupun demikian di dalam masyarakat industri ( masyarakatnya sudah maju ) kelompok kepentingan tipe ini juga memainkan peran politik.

c. Kelompok institusional, merupakan kelompok kepentingan yang bersifat formal. Kelompok kepentingan institusional ini sudah terorganisir secara rapi dan teratur. Demikian pula kelompok kepentingan tipe ini memiliki fungsi-fungsi sosial dan politik yang lainnya disamping berfungsi mengartikulasikan kepentingan. Keanggotaan Kelompok Kepentingan Institusional terdiri dari orangorang yang profesional di bidangnya. Untuk dapat masuk menjadi anggota kelompok kepentingan tipe ini diperlukan persyaratanpersyaratan formal yang memang telah ditentukan terlebih dahulu. Demikian pula kelompok kepentingan tipe ini telah memiliki renacana kerja yang tersusun dengan baik. kelompok institusional seperti partai politik, korporasi bisnis, badan hukum dan sebagainya.

d. Kelompok assosiasonal, yaitu kelompok yg terorganisir yg menyatakan kepentingan dari suatu kelompok tertentu dan memiliki prosedur teratur dan memiliki struktur organisasi yang formal. Kelompok kepentingan ini di dalam memperoleh pendukungpendukungnya juga melalui prosedur-prosedur yang formal. Demikian pula halnya untuk memilih atau menyeleksi siapakah yang akan dijadikan pimpinan, dan untuk merumuskan kebijaksanaankebiajaksanan kelompok harus melalui prosedur-prosedur yang teratur yang kadang-kadang cukup berbelit-belit. Contoh kelompok ini adalah serikat-serikat buruh, serikat-serikat dagang, perkumpulanperkumpulan para pengusaha. Kelompok kepentingan tipe ini secara khas menyatakan atau mengartikulasikan kepentingan-kepentingan dari kelompok yang tertentu; demikian pula kelompok kepentingan tipe ini telah memiliki tenaga-tenaga yang sudah profesional di bidangnya.

\section{b. Pesan Politik}

Pesan adalah komponen yang paling substansial dalam komunikasi. Pesan adalah sesuatu hasil karya komunikator yang dianggap dapat mewujudkan motif (maksud) komunikasinya. Dibalik pesan ada niat dari sang pengirim pesan, jadi komunikasi adalah bagaimana keberhasilan pengirim pesan untuk menyampaikan, memahamkan atau mempengaruhi sang penerima pesan. Intinya pesan adalah maksud dan tujuan dari interaksi di antara manusia. Pesan yang kita sampaikan bisa berdampak pada hubungan (relasi) antara pengirim dan penerima, apakah akan menjadi sebuah kesepakatan, persetujuan dan mempererat pertemanan (relasi) atau 
menjadi pertentangan yang berdampak penolakan bahkan permusuhan. Pesan hasil karya komunikator bersifat abstrak dan tidak dapat diketahui orang lain. Untuk mengubah bentuk abstrak menjadi bentuk yang konkrit komunikator harus menggunakan lambang (simbol). Jadi lambang (simbol) berfungsi untuk mengubah pesan yang abstrak menjadi konkrit. Teori Transformasi Generatif dari Noam Chomsky, ${ }^{32}$ berpendapat bahwa berbahasa merupakan kegiatan asasi manusia. Manusia secara genetis, dilengkapi dengan kemampuan berbahasa. Kemampuan itu ada secara potensial dalam otak manusia. Chomsky menyebutnya language Acquasition Device (LAD), sehingga bisa dikatakan gejala berbahasa pada manusia bukan suatu yang kebetulan. Menurut Ernst Cassirer, sebagai sistem sistem simbol, bahasa adalah mata rantai ketiga yang hanya ditemukan pada manusia. Mengutip ahli biologi Johannes Von Uexkull, menyebutkan sistem reseptor dan sistem efektor sebagai dua mata rantai yang terdapat pada hewan dan manusia. Dengan mata rantai ketiga itu, maka manusia hidup dalam dimensi yang baru dan luas. Sehingga manusia disebut sebagai animal symbolicum, makhluk pembuat dan penafsir simbol. Terkait hal tersebut, manusia juga merupakan animal rationale yang hanya sanggup memuat satu segi saja dari manusia, yaitu "rasio". Dalam otak manusia ada daerah Broca, daerah Wernicke dan daerah Angular yang memungkinkan lahirnya kemampuan berbahasa. ${ }^{33}$ Dengan kombinasi kerja yang terpadu dan kompleks dari seluruh bagian otak, kegiatan berbahasa itu mendapatkan pemadatan fungsi, yang terangkum dalam sebuah kata: "berpikir". ${ }^{44}$

Lambang-lambang yang digunakan oleh komunikator untuk mengkonkritkan motif-nya harus ditentukan dengan melakukan pemilihan lambang (simbol) yang tepat dan relevan sesuai konteks. Lambang-lambang sering disebutkan dengan istilah bahasa. Kegiatan berbahasa adalah pekerjaan otak yang paling tinggi dan canggih, yang membedakan manusia dengan makhluk lainnya. Sebagai alat komunikasi ada dua hal yang sangat penting, yaitu bahasa dan tangan. Keduanya menjadi sarana untuk berkomunikasi, bahasa diperagakan bukan dengan mulut saja, tapi semua gerak tubuh mulai dari wajah, kaki, gerakan tubuh dan juga tangan seperti

\footnotetext{
32 Taufik Paisak, Revolusi IQ/EQ/SQ: Antara Neorsains dan Al-Qur'an, Bandung: PT. Mizan Pustaka, 2004, hlm. 145

33 Paul Broca (1860) menemukan bahwa adanya kerusakan pada daerah tertentu di otak (kemudian hari lokasi ini disebut area Broca) menimbulkan kesulitan berbicara, yang disebut afasia ekspresif atau afasia motoric. Si pembicara memang dapat berbicara, namun kata-katanya hampir tanpa makna. Aksentuasinya pun lambat dan tidak tegas. Carl Wenicke (1874), peneliti Jerman menemukan adanya kerusakan pada daerah tertentu (kemudian hari dinamakan daerah Wernicke) yang dapat membuat seseorang kesulitan untuk berbahasa. Jika daerah ini rusak, ucapan orang lain masih dapat didengar, demikian juga huruf-huruf masih dapat dibaca, tetapi semua informasi itu tidak dapat dimengerti. Kata-kata yang diucapkan tidak bermakna sama sekali. Kata-kata yang digunakanpun salah. Kerusakan pada daerah ini disebut afasia reseptif atau afasia sensosris. Dejerine (1894) ahli saraf Prancis menemukan pusat bahasa yang lain di otak. Dia menemukan pusat itu pada lobus parientalis yang bertanggung jawab untuk masuknya pengertian dan pemanduan bahasa lisan dan tulisan yang masuk ke otak. Bagian ini dinamainya genus angular. (Ibid, hlm. 143-144).

${ }^{34} \mathrm{Ibid}, \mathrm{hlm} .147$
} 
komunikasi tuna wicara dan tuna rungu yang mempunyai cara khusus dengan menggunakan kode-kode yang dibentuk dengan tangan. Ini hasil kerja otak manusia dalam peradaban, kebudayaan yang menciptaan simbolsimbol selama bertahun-tahun. Bahasa terdapat dua kelompok. Bahasa verbal (umum) artinya sudah baku digunakan, seperti bahasa lisan dan tulisan. Bahasa non verbal (khusus) belum baku digunakan atau bahasa tanpa katakata, seperti bahasa isyarat, morse, gerak-gerik, mimik muka, bunyi, intonasi, dan lain-lain. Lambang (simbol) dalam bahasa memiliki makna (arti) bagi penggunanya. Makna sebuah lambang sangat tergantung pada orang yang menafsirkannya.

Komunikasi memiliki prinsip: "Words don't mean, but people mean", muatan kata-kata justru terletak pada penafsiran masing-masing orang atau kita mengenalnya dengan persepsi. Sebagian filosof mengatakan dunia ini adalah dunia tempat ia ditangkap, dan terutama dipersepsi, oleh pancaindra dan otak. ${ }^{35}$ Kata-kata (words), dan pedang (Sword) merupakan dua alat yang dapat menghasilkan kuasa. Bila kita lihat di era masa lampau, kontrol kekuasaan dilakukan melalui senjata-senjata sederhana, seperti pedang, tombak, panah, kampak dan lain-lain. Dan masa kini, senjata sudah berubah dengan pistol, granat, bom, nuklir, pesawat tempur, tank, kapal selam dan sebagainya sebagai alat untuk memperoleh dan mempertahankan kekuasaan. Dalam dunia militer, organisasi dan kehidupan sehari-hari, kata-kata memiliki pengaruh yang sangat kuat. Sebagai contoh perintah komando komandan kepada prajurit, mulai dari kegiatan baris-berbaris, latihan perang sampai peristiwa pertempuran nyata sangat mengandalkan penggunakan kata-kata yang sifatnya perintah yang harus dilaksanakan. Dalam organisasi juga terlihat bagaimana arahan, perintah atasan kepada bawahan. Begitu pula dalam kehidupan sehari-hari, percekokkan, konflik, sampai tindakan pidana bisa jadi bermula dari "kata-kata" yang tidak berkenan di hati penerima pesannya.

Secara simbolis bahasa dan tangan merupakan alat kekuasaan manusia. Di dalam dunia politik banyak menggunakan simbol-simbol, seperti warna yang dipilih, logo atau lambang partai, dan atribut lainnya yang mencerminkan identitas atau orientasi politiknya. Semua simbol tersebut pada dasarnya tidak bermakna apa-apa, tetapi manusia atau para aktor politik yang menafsirkannya. Penafsiran tidak terletak pada simbolnya tetapi ada di pikiran orangnya. Bagaimana manusia menafsirkan simbol sangat dipengaruhi oleh pendidikan dan pengalamannya, sehingga dalam memilih lambang yang akan digunakan komunikator politik untuk mewujudkan motifnya harus memperhatikan kemampuan (pendidikan dan pengalaman) komunikan atau khalayak politik. Semakin tinggi pendidikan dan semakin banyak pengalaman komunikan akan semakin baik kemampuannya untuk memahami simbol. Budaya masyarakat juga turut mempengaruhi bagaiamana memberi arti pada simbol, ini bisa dilihat pada saat masa

${ }^{35} \mathrm{Ibid}, \mathrm{hlm} .140$ 
kampanye pemilu. Banyak poster-poster partai, kandidat dengan beraneka bentuk, kaos-kaos partai dan atribut lainnya.

Selanjutnya pesan adalah output dari gagasan komunikator yang mempunyai unsur-unsur pembentuk sesuatu makna yang akan dipahami atau diterima oleh komunikan. Unsur-unsur pesan tersebut adalah: Isi, Struktur, Format pesan. Dengan mengelola pesan dengan baik akan sangat efektif, yaitu bagaimana pesan komunikator dapat sampai dan juga difahami oleh komunikan.

\section{Isi Pesan}

isi pesan adalah kandungan (materi) yang akan disampaikan. Materi pesan dalam hal ini adalah berisi masalah politik, mulai dari kekuasaan, pengaruh, kebijakan dan lainnya. Isi pesan perlu dikemas untuk dapat merangsang komunikan sehingga bereaksi sebagaimana yang diharapkan komunikator. Isi pesan dapat dirancang untuk merangsang akal sehat (logika) komunikan, disebut sebagai pesan rasional. Isi pesan dapat dirancang untuk merangsang perasaan (emosi) komunikan, maka disebut dengan pesan emosional. Lalu isi pesan juga dapat dirancang untuk merangsang moral, rasa keadilan dan kemanusiaan komunikan, atau disebut sebagai pesan moral. Isi pesan dapat dirancang dengan mengkombinasikan semua pesan diatas, yaitu untuk merangsang logika, emosi, dan moral komunikan.

\section{Struktur Pesan}

Struktur pesan adalah susunan agar pesan lebih efektif dan efesien. Struktur yang baik akan meningkatkan efektifitas. Misalnya susunan yang sistematis membuat pembaca atau pendengar lebih mudah paham. Struktur pesan yaitu susunan pokok-pokok gagasan yang menyatu menjadi satu kesatuan pesan yang utuh. Untuk merancang struktur pesan harus memperhatikan sikap khalayak sasaran terhadap pesan dan tujuan komunikator. Struktur pesan yang dapat dirancang dengan dua cara, yaitu pro-kontra dengan kontra-pro dan satu sisi dengan dua sisi. Dalam struktur pro-kontra, komunikator mendahulukan argumen atau gagasan yang selaras dengan pendapat atau sikap khalayak, selanjutnya gagasan yang bertentangan dengan sikap khalayak disajikan pada bagian akhir pembicaraan. Sebaliknya dalam struktur kontra-pro, komunikator mengawali presentasinya dengan mengemukakan gagasan yang berlawanan, selanjutnya presentasi ditutup dengan argumentasi pro khalayak. Struktur satu sisi artinya komunikator hanya menyajikan gagasan pada satu dimensi saja, misalnya aspek baik atau keuntungan saja yang dibicarakan dari pesan tersebut tanpa memperhatikan kerugian yang akan diterima. Sedangkan pada struktur dua sisi, komunikator menyajikan program yang akan dilaksanakan dengan melihat sisi keuntungan dari kerugian secara proporsional. 
Struktur pesan berbagai intensitas komunikasi perlu dipikirkan dan dirancang sedemikian rupa untuk memperoleh hasil yang diinginkan. Dalam dunia politik intensitas atau tingkatan pesan secara garis besar ada dua, yaitu pesan yang berlandaskan fakta dan pesan yang dirancang, direkayasa (setting) yang ditambahi informasi yang tidak berdasarkan fakta tapi sudah ada unsur lain yang memperkuat pesan agar dapat mempengaruhi komunikan, seperti penjelasan, pembenaran, bujukan, bahkan sampai pada ancaman, ketakutan dan kekerasan. Ada beberapa cara agar pesan persuasi dapat mengarah ke tindakan (action), diantaranya menurut Wilbur Schramm ${ }^{36}$, kondisi yang mendukung sukses tidaknya penyampaian pesan (message), yaitu:

1) Pesan dibuat sedemikian rupa dan selalu menarik perhatian,

2) Pesan dirumuskan melalui lambang-lambang yang mudah dipahami atau dimengerti oleh komunikan,

3) Pesan menimbulkan kebutuhan pribadi dari komunikannya,

4) Pesan merupakan kebutuhan yang dapat dipenuhi, sesuai dengan situasi dan keadaan kondisi dari komunikan.

Selanjutnya bisa juga dengan teknik yang dikenal dengan " $A$ A procedure, from attention to action", atau dengan formula atau struktur dengan slogan "AIDDA"37, yang merupakan singkatan dari:

1) A (attention), menarik perhatian, bisa merupakan sesuatu yang baru, sesuatu yang sering muncul seperti trending topic di dunia maya, ataupun di media massa, berita yang sering dimunculkan.

2) I (interest), membangkitkan minat, bisa merupakan sesuatu yang berbeda, sesuatu yang tidak biasanya, karena manusia cenderung mempunyai sifat bosan dan jenuh terhadap sesuatu yang rutinitas dan statis.

3) D (desire), menumbuhkan hasrat, bisa dalam bentuk sesuatu yang mengadung harapan.

4) D (decision), membuat keputusan, karena sudah dipandang penting, logis, dan ada dorongan dari diri sendiri untuk dapat dilaksanakan.

5) A (action), melakukan tindakan (aksi), aksi merupakan ukuran dari keberhasilan penyampaian pesan yang dilaksanakan oleh komunikan pada waktu dan tempat yang tepat.

\footnotetext{
${ }^{36}$ Rosady Ruslan, Kiat dan Strategi Kampanye Public Relation, Jakarta: PT. Raja Grafindo Persada, 2005, hlm. 38

37 Ibid, hlm. 39
} 
Proses penyampaian pesan dapat berlangsung dalam waktu yang singkat dan juga bisa berlangsung dalam waktu yang lama dan terusmenerus. Dengan kedua cara tersebut penyampaian pesan akan menimbulkan efek dalam bentuk menarik perhatian, simpati, empati dan juga bisa terjadi sebaliknya, yaitu antipati bahkan bisa juga reakasi yang menyerang balik pengirim pesan, terutama berkaitan dengan pesan politik. Pesan dapat juga berupa berita yang disampaikan kepada khalayak. Teknis penulisan berita pun harus memenuhi persyaratan $5 \mathrm{~W}+1 \mathrm{H}$ (who, what, whrere, when, why, dan how). Pesan harus merujuk pola logika penulisan yang sistematis, yaitu "piramida terbalik", artinya berita yang dianggap paling penting terletak di paragraph paling atas dengan porsi yang lebih banyak, lalu diikuti bagian yang kurang penting sampai pada pesan yang tidak penting.

\section{Format (Bentuk) Pesan}

Pesan dapat dirancang dan dikemas sesuai kondisi dan situasi yang sesuai agar penyampaian pesan akan tepat dan efektif dan efesien. Format pesan adalah pemilihan bentuk pesan (bahasa, lambang, cara) yang berfungsi mengkonkritkan motif (tujuan) komunikasi. Format pesan juga tergantung bentuk komunikasi (saluran) yang digunakan. Berikut ini adalah bentuk pesan sesuai intensitasnya:

\section{a. Pesan Pemberitahuan}

Bisa disebut juga pesan berupa 'pengumuman', yaitu pesan yang hanya mengandung fakta-fakta saja, tanpa memberikan penjelasan. Tujuannya agar pesan sampai kepada yang berhak menerima dan mengetahui. Contohnya penyampaian mengenai kebijakan-kebijakan pemerintah dalam bentuk peraturan atau regulasi atau sosialisasi politik mengenai isi dan praktek undang-undang kepada masyarakat, bisa dalam bentuk buku, selebaran, atau dalam bentuk berita di media massa dan media online. Bisa juga seorang calon kandidat baik legislatif atau eksekutif melakukan publisitas dengan tujuan awal agar publik faham niat dan usahanya untuk mengikuti proses pemilihan.

Pesan pemberitahuan juga bisa berbentuk iklan politik. Iklan politik adalah iklan non komersial, karena mengarah kepada pengiklanan citra (image), daya tarik yang diarahkan untuk membangun reputasi seorang pejabat publik atau kandidat yang akan menyalon (maju dalam pemilihan). Iklan politik juga menyajikan informasi kepada khalayak berkaitan dengan profil, kepribadian, pengalaman, kopetensi dan kualifikasi seorang politikus atau kandidat, sehingga mendorong prospek calon pemilih. Citra seorang figur kandidat memang perlu bila ingin dipilih oleh khayalak banyak. Citra 
adalah gambaran (image) yang muncul dihadapan masyarakat umum, bisa terbentuk berdasarkan aktifitas yang alamiah dari sesorang atau memang dengan upaya sengaja untuk dibentuk agar masyarakat umum mengenal sosok kandidat. Secara alamiah bisa jadi kandidat adalah tokoh masyarakat, atau aktifis, pejabat publik, artis atau anak keturunan dari tokoh terkenal yang memang sudah memiliki modal sosial, yaitu popularitas. Bagi yang sama sekali belum dikenal memang perlu kerja ekstra untuk dapat dikenal, popular sampai masyarakat mulai terbiasa dengan sosok baru yang akan maju dalam suatu pemilihan (election). Memang perlu mempunyai semacam tim khusus yang bekerja atau berperan sebagai Public Relation Politik atau Marketing Politik agar upayanya terbantukan.

\section{b. Pesan Informatif}

Pesan ini mempunyai struktur, yaitu fakta yang benar-benar terjadi dengan adanya penjelasan terhadap fakta tersebut. Contohnya informasi perjalanan sidang-sidang komisi di DPR RI dalam membahas masalah rancangan undang-undang dan pengesahannya, masalah anggaran yang biasanya sangat sensitif, lalu rapat kabinet tertentu juga menjadi hak publik untuk mengetahuinya, untuk mendapatkan penjelasan. Saat ini media massa khususnya beberapa stasiun televisi kerap menayangkan perjalanan sidang tersebut secara langsung (live). Setiap perencanaan, program atau kebijakan yang telah diputuskan seharusnya menjadi suatu informasi yang harus diketahui secara luas oleh masyarakat. Pemerintah, Parlemen dan semua lembaga tinggi negara yang terkait dengan masalah hak dan kewajiban umum wajib melakukan sosialisasi atau membuat upaya penjelasan agar dipahami oleh masyarakat. Apalagi bila terjadi pada masyarakat dengan katogori berbudaya politik parokial (parochial political culture), yaitu tingkat partisipasi politiknya sangat rendah, yang disebabkan faktor kognitif misalnya tingkat pendidikan relatif rendah. Kalau tidak ada sosialisasi atau penjelasan (kondisi pasif), tidaklah mungkin masyarakat akan mengetahui, memahami apalagi muncul suatu kesadaran.

Begitu pula peristiwa yang ada di lembaga tinggi lainnya, sehingga adanya transparansi terhadap kronologis suatu peristiwa dan fakta. Ada juga informasi terhadap tersangka pelanggaran etik atau kasus suap, korupsi dan gratifikasi yang harus dipublikasikan beserta penjelasan atau kronologisnya, bisa dilakukan dalam bentuk konfrensi pers oleh lembaga yang terkait, misalnya oleh Komisi Pemberantasan Korupsi (KPK) atau oleh pemerintah langsung. Di era infomasi global dan teknologi semakin canggih, kontrol sosial akan semakin kuat sehingga masyarakat secara umum akan terus mengawasi proses belangsungnya roda pemerintahan. Opini publik ternyata menjadi kekuatan pada saat penguasa berlaku sewenang-wenang dan bila terjadi kejanggalan atau pelanggaran dalam mengemban amanah rakyat. 
Terlebih fenomena opini di dunia maya atau netizen yang kerap membuat pemeritah, atau aktor-aktor politik dapat berinteraksi dan mengetahui langsung dengan beragam opini terhadap isu-isu tertentu yang menjadi topik yang sedang menjadi pembicaraan penting bagi masyarakat (trending topic).

\section{c. Pesan Persuasif}

Merupakan pesan yang berusaha untuk membujuk, mempengaruhi, merubah pemikiran, prilaku, sikap mental, keyakinan orang melalui katakata lisan dan juga tertulis. Menurut Nasution (1990) persuasi politik adalah sesuatu yang esensial bagi politik, karena merupakan aspek atau motivasi dari "who says what" dalam politik. Persuasi politik menanamkan opini baru dan suatu usaha sadar untuk mengubah sikap mental, keyakinan atau prilaku orang melalui transmisi sejumlah pesan. Persuasi adalah suatu upaya, maksud untuk mencapai suatu tujuan tertentu (misi) dari komunikator melalui pembicaraan. Persuasi juga bersifat dialektikal atau merupakan proses resiprokal (timbal-balik) dimana komunikator berusaha dengan sadar atau tidak sadar membangun suatu tali penghubung (chord) yang responsif dengan pihak yang lain yang menjadi sasaran pesan. Pesan persuasif terjadi secara intensional (disengaja) dan di program, legal dan sistematis seperti pada kampanye pemilu, tapi juga bisa secara tidak sengaja (unintentional), seperti adanya kejadian yang insidental berupa demonstrasi, huru-hara yang sifatnya spontan. Jadi pada dasarnya pendekatan persuasi politik bersifat purposive (bertujuan), intensional dan menyangkut pengaruh, semua terdiri dari hubungan-hubungan yang resiprokal antar orang ketimbang antara seseorang yang mendikte orang lain. Semua menghasilkan perubahan dalam persepsi, keyakinan, nilai-nilai dan ekspektasi pribadi dan juga kelompokkelompok di masyarakat. ${ }^{38}$

Berkaitan tindakan persuasi politik kepada kelompok biasanya dilakukan dengan upaya persuasi melalui tokoh atau orang penting yang ada di kelompok tersebut, atau biasa di sebut pemimpin opini (opinion leader). Upaya yang dilakukan untuk persuasi politik adalah dengan cara: 1) awareness (kesadaran), 2) indoktrinasi ${ }^{39}$ dan 3) brainwashing 40 kepada target

\footnotetext{
${ }^{38}$ Nasution, OP, Cit, hlm. 106

39 Indoktrinasi: pemberian ajaran secara mendalam (tanpa kritik) atau penggemblengan mengenai suatu paham atau doktrin tertentu dengan melihat suatu kebenaran dari arah tertentu saja; sebuah proses yang dilakukan berdasarkan satu sistem nilai untuk menanamkan gagasan, sikap, sistem berpikir, perilaku dan kepercayaan tertentu.

${ }^{40}$ Brainwashing: Metode utama yang digunakan adalah dengan memasukkan informasi berupa dogma-dogma secara rutinitas (kebiasaan) atau dengan ritual tertentu. Media yang digunakan adalah forum-forum pertemuan yang rutin dalam suatu kelompok, organisasi atau sebuah negara. Salah satu prakteknya adalah dengan membuat ikatan sumpah setia yang menjadi alat kontrol. lalu juga menggunakan audio dan visual secara waktu berkala dan panjang, dan bersifat terfokus. Sebuah informasi yang ditekankan dan dimasukkan secara terfokus, dengan akses audio maupun visual, dan dilakukan secara terus menerus, mampu menggiring persepsi dan pola pikir maupun perasaan seseorang sedikit demi sedikit. Inilah yang disebut sebagai memasukkan nilai di bawah sadar seseorang. Ketika sebuah nilai telah tertanam cukup kuat di dalam bawah sadar seseorang, maka nilai itu lama kelamaan semakin kuat, berakar, dan permanent.
} 
sasaran pesan persuasif. Awareness adalah kesadaran yang bangkit dari internal diri seseorang setelah diberikan pengetahuan, pemahaman, dan tidak ada paksaan dan tekanan dari pihak luar (eksternal). Indoktrinasi merupakan pesan yan isinya adalah bisa jadi sebuah pesan yang biasanya berdasarkan rekayasa (non fakta), bujukan, ancaman, paksaan, bahkan kekerasan verbal dan psikis demi kepentingan komunikator. Brainwashing: secara bahasa adalah mencuci otak, yaitu dengan cara mementahkan atau mengosongkan nilai dan keyakinan seseorang, sehingga orang yang sedang di-brainwashing akan apatis terhadap keyakinan yang lama.

Selanjutnya dalam kondisi yang sudah kosong atau bersih akan lebih mudah masuk keyakinan atau nilai-nilai baru. Brainwashing menggunakan kombinasi berita rekayasa (non fakta), adanya ancaman dan siksaan fisik dan non fisik demi berubahnya isi pikiran komunikan. Pesan persuasif merupakan penggabungan atau kombinasi antara fakta, dan non fakta, penjelasan dan bujukan (harapan) yang disampaikan agar komunikan terbujuk atau terpengaruh sampai pada tahap terjadinya perubahan sikap dari apatis (menolak) sampai tergerak dan mendukung, bahkan merasa membutuhkan dan menjadi bagian dari apa yang diprovokasikan oleh komunikator. Sehingga misi atau tujuan dari komunikator bisa dikatakan berhasil. Namun, pesan persuasif juga berpotensi mendapatkan penolakan bila terjadi kegagalan dalam upayanya tersebut. Dalam bentuk praktek persuasi adalah: retorika, agitasi, propaganda, iklan politik, dan kampanye.

\section{i. Retorika}

Retorika adalah ilmu yang pada awalnya dikembangkan di Yunani oleh Aristoteles, yaitu jenis komunikasi publik. Retorika adalah seni berbicara (techne rhetorike) dengan melakukan komunikasi dua arah, satu-kepada-satu (one to one), dalam arti bisa jadi satu atau lebih (beberapa orang), dimana masing-masing berusaha dengan sadar untuk mempengaruhi pandangan satu sama lain melalui tindakan timbal balik satu sama lain (alat persuasi). ${ }^{41}$ Tradisi retorika memandang bahwa retorika haruslah mencari kebenaran, bukan mempermainkan kata-kata yang kosong atau tanpa makna dan tujuan. Kebenaran yang diungkapkan haruslah logis, realistis, dan rasional. Kebenaran itu absolut dan harus mempunyai nilai praktis bukan terhenti sampai di ucapan atau tataran konsep (angan-angan) saja. Retorika bisa dikatakan daya kemampuan berargumentasi dengan dasar fakta, data, logika, dan pengetahuan untuk mempengaruhi setiap orang yang mendapat pesan. Keputusan atau pengaruh yang bersifat emosional akan ditekan dengan argumen yang rasional yang berdasarkan fakta, data, logika dan pengetahuan. Kemampuan ini akan terus terasah sering waktu berjalan dan jam terbang pengalaman. Semakin sering memiliki pengalaman yang

\footnotetext{
${ }^{41}$ Nimmo, Op, Cit, hlm. 140
} 
beragam dalam beretorika semakin tajam argumen yang dilontarkan. Elemen-elemen pokok retorika ada tiga, yang pertama adalah komunikator (communicator) yang memiliki ethos (kredibilitas), authority correctness (daya untuk memperjuangkan kebenaran), appearance (penampilan), eloquence (kelancaran bicara). Kedua, pesan (message), yaitu informasi, argumentasi, penjelasan, bukti-bukti, data dan struktur (pesan yang efektif mempunyai alur mulai dari pembukaan, isi dan penutup), dan ketiga adalah audiens yang berkaitan dengan keyakinan, nilai, pengetahuan dan pengalaman yang membuat adanya koneksi antara komunikator dan audiens.

Komunikator juga perlu mempertimbangkan khalayak yang akan dihadapi, dan juga harus menjalankan konsep ethos (niat baik pembicara, karakter, dan intelengensi) hal tersebut bisa dipelajari dan dibiasakan, pathos (berkaitan dengan emosi yang ditimbulkan kepada khalayak), dan logos (penggunaan argument, rasionalisasi, dan wacana yang digunakan), logika yang digunakan yaitu silogisme, yaitu sekelompok proposisi yang berhubungan satu sama lain dan menarik sebuah kesimpulan dari premispremis mayor dan minor (kepastian) dan etimen, yaitu silogisme yang berdasarkan pada kemungkinan (probability), tanda (sign), dan contoh (example) yang berfungsi sebagai persuasi retoris. Nimmo (1998) juga melukiskan sifat dasar retorika adalah suatu bentuk persuasi yang menonjolkan komunikasi dua arah, dialektika, negosiasi dan drama. Praktek retorika politik bisa kita lihat dalam perdebatan di dalam ruangan sidang anggota Dewan Perwakilan Rakyat (DPR). Contoh upaya mempertahankan opini dan menyakinkan seluruh anggota dewan yang dilakukan oleh suatu fraksi partai politik terhadap Rancangan Undang-Undang (RUU) dengan menggunakan argumentasi yang diperkuat dengan fakta, logika, dan juga kadang dengan pendekatan humanisme. Bisa juga contoh di Amerika bagaimana pengacara berargumentasi di depan juri di pengadilan atau di depan para hakim untuk upaya persuasi, dan juga adu argumentasi dalam perdebatan calon presiden yang ditonton oleh banyak masyarakat yang tujuannya untuk menunjukkan kemampuan dan kopetensi para kandidat. Bentuk lain dari praktek retorika adalah melalui pidato politik.

Retorika politik adalah proses mempengaruhi seseorang atau khalayak dengan negosiasi yang bertujuan untuk meraih dan mempertahankan kekuasaan atau menjalankan kewenangan. Retorika menggunakan bahasa untuk mengidentifikasi pembicara dan pendengar melalui pidato. Jadi pidato adalah negosiasi diamana proses memberi dan menerima secara kreatif. Dalam proses itu orang-orang menyusun makna bersama bagi kata-kata dan lambang-lambang, penempatan posisi sebagai lawan dan kawan dalam perdebatan yang merupakan identitas posisi masing-masing. Retorika bersifat transaksional dan menggunakan lambang untuk mengidentifikasi pembicara dengan para pendengarnya. Tujuannya adalah untuk melakukan persuasi dan membangun citra atau gambaran padangan dari pembicara (komunikator) tentang program atau visi dan misinya (tujuan). Melalui retorika persuader dan yang dipersuasi saling bekerja sama dalam 
merumuskan kepercayaan, nilai dan pengharapan mereka. Sifat ini disebut oleh Kenneth Burke ${ }^{42}$ sebagai "konsubstansialitas", yaitu orang-orang bertindak bersama-sama dan memiliki perasaan, konsep, citra, gagasan dan sikap yang sama (konsubstasial). Kesadaran akan identifikasi seperti itu inheren dalam retorika. Identifikasi adalah proses membangkitkan kesadaran bekerja sama pada suatu khalayak dengan pembicara sehingga khalayak merasa bahwa mereka berpartisipasi dengan pembicara dalam menciptakan dan mencapai tujuan. Aristoteles menyebutkan tipologi retorika dalam bukunya "Rethorica", dia mengidentifikasi ada tiga cara pokok dalam hal praktek retorika, seperti yang dijabarkan dalam tabel berikut ini:

Tabel 4.1. Tipologi Retorika (sumber: Dan Nimmo, 1998: 142-143)

\begin{tabular}{|l|l|l|l|}
\hline Jenis Retorika & \multicolumn{1}{|c|}{ Fokus } & \multicolumn{1}{|c|}{ Tujuan } & \multicolumn{1}{c|}{ Contoh } \\
\hline 1. Deleberatif & $\begin{array}{l}\text { Kebijakan } \\
\text { masa depan. }\end{array}$ & $\begin{array}{l}\text { Mempengaruhi } \\
\text { orang-orang dalam } \\
\text { masalah kebijakan } \\
\text { pemerintah dengan } \\
\text { mengambarkan } \\
\text { keuntungan dan } \\
\text { kerugian, serta cara- } \\
\text { cara alternatif. }\end{array}$ & $\begin{array}{l}\text { Ketika pemerintah menaikkan } \\
\text { harga BBM, dengan argument } \\
\text { pengalihan subsidi untuk } \\
\text { pembangunan infratruktur. }\end{array}$ \\
\hline 2. Forensik & $\begin{array}{l}\text { Yang terjadi } \\
\text { di masa lalu. }\end{array}$ & $\begin{array}{l}\text { Menunjukkan } \\
\text { bersalah atau tidak } \\
\text { bersalah, } \\
\text { pertanggungjawaban, } \\
\text { hukuman dan } \\
\text { ganjaran. }\end{array}$ & $\begin{array}{l}\text { Terjadi di ruang persidangan, } \\
\text { bisa di Pengadilan tinggi } \\
\text { Negara, Mahkamah konstitusi, } \\
\text { kasus yang menyeret para } \\
\text { koruptor. }\end{array}$ \\
\hline 3. $\begin{array}{l}\text { Demonstratif } \\
\text { (Epideiktik) }\end{array}$ & $\begin{array}{l}\text { Wacana } \\
\text { memuji atau } \\
\text { menjatuhkan. }\end{array}$ & $\begin{array}{l}\text { Memperkuat sifat } \\
\text { baik dan sifat buruk } \\
\text { seseorang, lembaga, } \\
\text { atau gagasan. }\end{array}$ & $\begin{array}{l}\text { Kampanye politik, seperti satu } \\
\text { pihak menantang kualifikasi } \\
\text { pihak lain bagi jabatan di } \\
\text { dalam pemerintahan. Bisa } \\
\text { dalam bentuk debat kanditat } \\
\text { presiden yang di siarkan oleh } \\
\text { media massa. }\end{array}$ \\
\hline
\end{tabular}

Berdasarkan tipologi Aristoteles bahwa bila hanya satu jenis retorika saja tidak akan memadai untuk mempersuasi orang dalam segala situasi. Nimmo (1998) mencontohkan suasana di ruang sidang pengadilan akan menjadi saling mencaci bila terjadi upaya demonstratif dari para pengacara atau para peserta yang menghadiri sidang. Hakim sebagai pengendali sidang harus mempunyai ketegasan dalam mengatur suasana sidang dengan retorika forensik. Retorika demonstratif akan sangat terlihat dan iklimnya akan sangat memanas saat-saat masa Pemilu. Bisa juga terjadi pada saat unjuk rasa mahasiswa, buruh pabrik, atau elemen masyarakat lainya yang menuntut suatu keadialan, transparasi, kenaikan upah dan lain sebagainya.

${ }^{42}$ Nimmo, Op, Cit, hlm. 141 
Namun, kita bisa melihat semua jenis retorika berfungsi dan terimplementasi pada sidang-sidang di Parlemen, unsur deleberatif, forensik dan demonstratif melebur menjadi satu mulai dari sidang fraksi, sidang komisi sampai sidang paripurna dalam merumuskan atau menetapkan Undang-Undang dan juga anggaran negara.

\section{ii. Agitasi}

Istilah Agitasi berasal dari bahasa latin yaitu agitare yang berarti bergerak, atau menggerakkan. Komponen pesan agitasi terdiri dari fakta atau bisa juga non fakta, penjelasan, bujukan (mendorong, menekankan, menggerakkan), mensugesti, bahkan dengan menggunakan ancaman demi kepentingan tujuan komunikator atau disebut sebagai 'agitator'. Jadi pesan dalam bentuk agitasi bisa dikatakan suatu upaya yang dapat merangsang, membangkitkan perhatian (to excite) atau mendorong atau menggerakkan para penerima pesannya. Isi pesan agitasi cenderung dalam perspektif kritis, artinya akan mengarah untuk membangkitkan kesadaran dan emosi khalayak terhadap ketidakadilan, ketidaksesuaian, ketidakpastian, persamaan, penindasan, penderitaan, dan sebagainya sehingga menimbulkan kegelisaan di khalayak agar berani bertindak merubah nasibnya. Menurut Herbert Blumer ${ }^{43}$, agitasi beroperasi untuk membangkitkan rakyat kepada suatu gerakan terutama gerakan politik. Agitasi dimulai dengan cara membuat kontradiksi dalam masyarakat dan menggerakkan khalayak untuk menentang kenyataan hidup yang dialaminya selama ini (ketidakpastian dan penderitaan). Bentuk agitasi contohnya adalah seorang orator politik yang berpidato dengan berapi-api, dan juga dalam debat politik para kandidat yang berusaha mencari kelemahan atau kekurangan lawannya.

Biasanya dilakukan oleh tokoh atau aktivis partai politik seperti berpidato dengan berapi-api untuk mempengaruhi massa. Pada masa kampanye menjelang pemilu, para kontestan dilarang mengagitasi karena dapat diartikan menghasut orang banyak yang berpotensi membangkitkan pergolakan massa (huru-hara), pemberontakan, dan seterusnya. Tokoh atau aktivis partai politik, ormas, yang merupakan sosok orang yang mempunyai pengaruh kuat di dalam masyarakat. Agitasi memfokuskan diri pada sebuah isu aktual, berupaya 'mendorong' suatu tindakan terhadap isu tersebut. Seorang agitator menyajikan hanya satu atau sedikit gagasan melalui saluran di depan publik umum (public speaking) dan bekerja terutama dengan kemampuan lisan dan juga tulisan. Pesan disajikan dan disampaikan ke sejumlah besar orang (a mass of people), agitasi membuat suatu generalisasi di mana adanya pengaruh langsung (direct influence) dari dominasi pendapat umum yang terbentuk setelah pesan agitasi sukses mempengaruhi masyarakat.

${ }^{43}$ Anwar Arifin, Komunikasi Politik (Filsafat, Paradigma, Teori, Tujuan, Strategi dan komunikasi politik Indonesia), Yogyakarta: Graha Ilmu, 2011, hlm. 131 
Agitasi lazim dilakukan di negara otoriter dan negara komunis seperti pada saat masa Nazi di Jerman, Uni Soviet, atau di era sekarang adalah negara Korea Utara. Di negara dengan sistem demokrasi (Amerika, Eropa, termasuk Indonesia), pesan agitasi kurang di sukai dan tidak mendapatkan tempat serta mendapat stigma negatif di masyarakatnya. Agitasi kerap dilakukan di internal organisasi atau partai agar pengikutnya tetap menjaga kegairahan, semangat dan loyalitas serta bersedia melakukan pengorbanan jiwa dan raga untuk mewujudkan cita-cita politik yang mereka perjuangkan.

\section{iii. Propaganda}

Propaganda dan agitasi adalah bentuk komunikasi dari satu kepada banyak (one to many). Propaganda (latin: propagare) berarti menanamkan, cara tukang kebun menyemai benih suatu tanaman ke sebuah lahan untuk mereproduksi tanaman baru yang kelak tumbuh sendiri. Secara sosiologis penyebaran ide dengan cara propaganda berarti bukan sesuatu yang muncul dengan sendirinya, melainkan sesuatu yang ditanamkan (cultivated) atau pembangkitan buatan (artificial generation), seperti merubah yang tadinya tidak beragama menjadi beragama. Tanpa adanya intervensi dari pihak luar maka orang-orang tersebut tidak akan mengetahui, memahami apalagi sampai meyakini dan menjalankan suatu ide, gagasan dan keyakinan. Penanaman ide, gagasan dan keyakinan yang dilakukan dengan perencanaan yang sistematis, bertahap berdasarkan rentan waktu tertentu. Propaganda adalah sebuah rencana sistematis atau gerakan bersama untuk penyebarluasan suatu keyakinan atau doktrin. Istilah propaganda berawal dari misi penyebaran keimanan kristiani kepada bangsa-bangsa lain pada tahun 1622 yang diprakarsai oleh Paus Gregorius XV, yaitu pembentukan komisi para kardinal, Congregatio de Propaganda Fide (The Congration of Propaganda). Lembaga ini terbentuk pada 1633 oleh Pope Urban VII yang bertujuan untuk mengembangkan dan memekarkan agama Katholik Roma. Para missioner tersebut ditugasi untuk menyebarkan doktrin dengan harapan seorang missioner dapat menyebarkan kepada ribuan pemeluk baru. Sehingga karakter khas dari propaganda adalah satu kepada banyak (one to many). Propagandis adalah seseorang atau sekelompok kecil yang menjangkau khalayak kolektif yang lebih besar. ${ }^{44}$ Jacques Ellul (sosiolog dan psikolog Prancis), mendefinisikan propaganda sebagai komunikasi yang digunakan oleh suatu kelompok terorganisir yang ingin menciptakan partisipasi aktif atau pasif dalam tindakan-tindakan suatu massa yang terdiri atas individuindividu, dipersatukan secara psikologis melalui manipulasi psikologis dan digabungkan di dalam suatu organisasi. ${ }^{45}$

Jadi propaganda adalah suatu gejala kelompok yang erat kaitannya dengan organisasi dan tindakan, tanpa dua hal tersebut propaganda praktis

\footnotetext{
${ }^{44}$ Nimmo, Op, Cit, hlm. 125
}

${ }^{45}$ Ibid. 
tidak ada. Propaganda yang efektif hanya dapat bekerja di dalam suatu kelompok atau skup lebih besar adalah negara. Secara konkrit propagandis mencapai individu-individu melalui manipulasi lambang. Sebagai gambarannya seorang tokoh penting sebuah Partai politik berbicara di hadapan lautan manusia sebagai bentuk rapat umum dengan penampilan yang diatur secara cemat dan dikelilingi oleh bendera-bendera partai. Lalu tokoh penting tersebut menggunakan oratori yang penuh emosi untuk membangkitkan rasa identifikasi, komitmen, dan kesetiaan dari anggota atau pengikutnya, biasanya juga menggunakan slogan-slogan yang dapat memperkuat ikatan atau penguatan (kohesi) terhadap partai atau kelompoknya.

Komponen dari pesan propaganda adalah fakta dan bisa juga non fakta, adanya penjelasan dan bujukan demi kepentingan komunikator atau disebut sebagai 'propagandis'. Propaganda berurusan dengan penjelasan gagasan-gagasan secara terinci dan lebih sistematis. Seorang marxis perintis di Rusia, Plekhanov ${ }^{46}$ mengatakan, Seorang propagandis menyajikan banyak gagasan ke satu atau sedikit orang; setiap orang atau individu akan merasakan pengaruh secara personal (individual) yang merupakan hasil penyerapan informasi atau gagasan dari sebuah pesan propaganda. Propaganda, dalam keadaan yang menguntungkan, bisa meraih ribuan atau puluhan ribu orang dalam suatu proses pelahan, terus-menerus dan jangka waktu yang lebih panjang. Propaganda politik menurut Dan Nimmo ${ }^{47}$ merupakan suatu meknisme kontrol sosial. Propagandis berbicara seolaholah di antara dua orang yang bertatap muka untuk memberikan pesan bahwa pemimpin dan yang dipimpin tergabung di dalam suatu pihak. Namun, seorang propagandis sebenarnya hanyalah wakil atau petugas dari organisasi yang secara teknis melalukan suatu upaya berdasarkan prosedur (panduan), memilih kata-kata yang tepat, dan tindakan-tindakannya berdasarkan alasan-alasan yang sifatnya teknis semata-mata. Jadi propagandis adalah teknikus kontrol sosial.

Nimmo (1998) menjelaskan bahwa teori kontrol sosial menyatakan bahwa tatanan sosial dihasilkan oleh orang-orang yang secara kesinambungan belajar dan memperkuat kesetiaan politik, kepercayaan religius, pandangan sosial, kebiasaan, kaidan-kaidah, dan suatu cara hidup yang mendasar yang sama pada orang-orang tersebut. Namun, dalam masyarakat partisipasi rakyat yang luas di dalam peristiwa politik sangatlah dikehendaki oleh penguasa negara atau yang bercita-cita menjadi penguasa negara. Partisipasi masyarakat muncul berawal dari terbentuknya opini publik. Opini publik yang menguntungkan penguasa tidak mungkin muncul dengan hanya menunggu dan diam saja. Maka setiap kelompok atau organisasi harus giat memobilisasi dukukangan atau partisipasi publik.

\footnotetext{
${ }^{46}$ Duncan Hallas , Agitasi dan propaganda (1984), https://www.marxists.org/indonesia/archive/hallas/agitasi.htm, diakses 3 Juli 2016

${ }^{47}$ Nimmo, Op, Cit, hlm. 125
} 
Propaganda digunakan sebagai suatu mekanisme kontrol sosial untuk menyebarkan ideologi, membangkitkan kewaspadaan dari munculnya konflik dalam masyarakat luas, menciptakan hubungan yang erat diantara mereka, menggalang kesetiaan dan mempertahankan ketaatan kepada penguasa. ${ }^{48}$

Ada dua tipologi propaganda menurut Jacquel Ellul ${ }^{49}$, yaitu propaganda politik dan propaganda sosiologi. Propaganda politik melibatkan usaha-usaha pemerintah, partai, atau golongan yang berpengaruh untuk mencapai tujaun strategis atau taktis melalui imbauan-imbauan khas berjangka pendek, dan biasanya dilakukan secara terang-terangan, seperti yang terkait kebijakan dan regulasi. Propaganda sosiologi bisa dikatakan samar (tersembunyi), dan berjalan dengan jangka waktu yang panjang. Dengan cara ini orang atau masyarakat tertentu ditanamkan (disuntik) dengan cara atau gaya hidup budaya tertentu (seperti gaya hidup, fasion, musik Amerika yang ditiru banyak warga negara di dunia) atau ideologi yang berangsur-angsur merembes dalam tatanan struktur masyarakat, lembaga-lembaga ekonomi, sosial, budaya dan politik. Contoh Amerika telah menyebar ide mengenai American Super Hero sejak awal abad 20, seperti Superman, Captain America, dan sebagainya yang akhirnya menjadi idola anak-anak. Dampaknya mereka tidak terlalu mengidolakan pahlawan nasional mereka sendiri. Orang Korea Selatan digandrungi seperti K-Pop, Korean Wive, mereka ingin menjadi seperti orang Amerika dalam penampilan, rambut pirang, mata dilebarkan dengan operasi dan sebagainya.

Selanjutnya ada propaganda agitasi, yang berusaha agar orang-orang bersedia memberikan pengorbanan yang besar bagi tujuan yang langsung, mengorbankan jiwa mereka dalam usaha mewujudkan cita-cita dalam tahaptahap yang merupakan rangkaian, tujuan demi tujuan. Dengan agitasi, para pemimpin mempertahankan kegairahan para pengikutnya dengan memperoleh suatu kemenangan yang khas, kemudian memberi peluang untuk bernafas, diikuti oleh usaha yang lain dengan suatu inovasi dalam serangkaian tujuan. Lalu propaganda integrasi dengan menggalang kesesuaian di dalam mengejar tujuan-tujuan jangka panjang. Melalui propaganda ini orang-orang mengabdikan diri mereka kepada tujuan-tujuan yang mungkin tidak akan terwujud dalam waktu bertahun-tahun, bahkan selama mereka hidup. Dalam penggunaan saluran propaganda ada dua tipe yaitu propaganda vertikal, yang mengandalkan penyebaran imbauannya melalui media massa dan media baru. Lalu propaganda horizontal yang bekerja pada arus sejajar diantara keanggotaan kelompok daripada dari pemimpin kepada kelompok. Lebih banyak melalui komunikasi interpersonal dan komunikasi organisasi daripada komunikasi massa. Partai-partai politik lebih mengandalkan propaganda horizontal, dalam bentuk kunjungan ke daerah-daerah, pelatihan kader partai, dan sebagainya.

\footnotetext{
${ }^{48}$ Nimmo, Op, Cit, hlm. 126

${ }^{49}$ Ibid.
} 
Upaya persuasi melalui propaganda harus memperhatikan sejumlah faktor, yaitu memahami kondisi atau keadaan khayalak, kemampuan propagandis, dan teknik propaganda yang digunakan. Teknik propaganda yang digunakan akan memunculkan stimuli kepada khalayak. Propagandis harus memperhitungkan dan fokus pada kualitas stimuli dan bukan pada kondisi dan keadaan khalayak. Karena propaganda tujuannya untuk mempersuasi, mengarahkan, merubah khalayak, bukan malah propagandisnya yang terpengaruh kondisi khalayak. Ada beberapa teknik propaganda, yaitu:

Tabel 4.2: Teknik Propaganda. Sumber: Zulkarimen Nasution (1990), Nurudin (2001), Anwar Arifin (2011) (kompilasi dan modifikasi)

\begin{tabular}{|c|c|c|}
\hline No & Teknik Propaganda & Keterangan \\
\hline 1 & $\begin{array}{l}\text { Name Calling } \\
\text { (penggunaan Stereotip) }\end{array}$ & $\begin{array}{l}\text { Pemberian julukan tertentu kepada pihak lawan dengan } \\
\text { menggunakan nama atau panggilan yang berkonotasi } \\
\text { negatif (panggilan jelek). }\end{array}$ \\
\hline 2 & $\begin{array}{l}\text { Glittering Generalities } \\
\text { (penggantian nama yang } \\
\text { gemerlap, cemerlang, } \\
\text { bombastis, iming-iming) }\end{array}$ & $\begin{array}{l}\text { Menggunakan kata-kata atau menggunakan istilah yang } \\
\text { disenangi (kata bijak) atau yang tidak disenangi, kata- } \\
\text { kata muluk, slogan-slogan, mengidentifikasi } \\
\text { (menyanjung) diri sendiri dengan segala yang serba } \\
\text { luhur dan agung, bisa juga memutar balik fakta dengan } \\
\text { konotasi emosional, sehingga orang tanpa sadar } \\
\text { mengikutinya. }\end{array}$ \\
\hline 3 & $\begin{array}{l}\text { Transfer } \\
\text { (Pengalihan) }\end{array}$ & $\begin{array}{l}\text { Melakukan identifikasi dengan lembaga-lembaga otoritas } \\
\text { meliputi kekuasaan, sanksi, dan pengaruh sesuatu yang } \\
\text { lebih dihormati serta dipuja dari hal lain agar membuat } \\
\text { "sesuatu" lebih bisa diterima. Dengan cara pengalihan } \\
\text { pada objek lain, teknik ini digunakan dengan memakai } \\
\text { pengaruh seseorang atau tokoh yang dikagumi atau } \\
\text { berwibawa di lingkungan tertentu. Pengkaitan sesuatu } \\
\text { pihak yang berkompeten di bidang tersebut (the appeal to } \\
\text { authority), contoh tokoh agama, figur-figur legendaris, } \\
\text { profesi seperti dokter, dsb. }\end{array}$ \\
\hline 4 & $\begin{array}{l}\text { Testimonials } \\
\text { (pengakuan/ kesaksian) }\end{array}$ & $\begin{array}{l}\text { Pengulangan ucapan orang yang dihormati atau dibenci } \\
\text { untuk mempromosikan atau meremehkan suatu maksud. } \\
\text { Sering digunakan dalam kegiatan komersial, dan juga di } \\
\text { bidang politik sehingga terkesan di dukung oleh tokoh } \\
\text { tersebut. Memakai nama orang-orang terkenal seperti } \\
\text { bintang film, olahragawan, walaupun sebenarnya mereka } \\
\text { tidak memakai produk tertentu. }\end{array}$ \\
\hline 5 & $\begin{array}{l}\text { Plain Folks } \\
\text { (perendahan diri) }\end{array}$ & $\begin{array}{l}\text { Merakyat, menempatkan diri sebagai bagian dari rakyat, } \\
\text { blusukan, menciptakan kesan mengabdi kepada rakyat, } \\
\text { meskipun sudah menjadi pejabat (birokrat) tapi ingin } \\
\text { menampilkan image seperti kebanyakan orang, membaur } \\
\text { dan sederhana, seperti makan diwarteg, naik bis umum, } \\
\text { menggendong anak jalanan, partai "wong cilik" dan pasti } \\
\text { ada selalu bidikan kamera menyertai. }\end{array}$ \\
\hline 6 & $\begin{array}{l}\text { Card Stacking } \\
\text { (seleksi) }\end{array}$ & $\begin{array}{l}\text { Memilih dengan teliti hanya hal-hal tertentu yang sesuai } \\
\text { dengan tujuan, dari sekian banyak fakta yang ada. } \\
\text { Menyeleksi dan kegunaan fakta atau kepalsuan, ilustrasi }\end{array}$ \\
\hline
\end{tabular}




\begin{tabular}{|c|c|c|}
\hline & & $\begin{array}{l}\text { atau kebingungan dan masuk akal atau tidak masuk akal } \\
\text { (logis). Pernyataan mengemukakan fakta atau hal-hal } \\
\text { yang baik saja, sehingga publik hanya melihat dari satu } \\
\text { sisi saja. Agar meyakinkan publik dapat pula dengan } \\
\text { menutupi hal yang factual dengan bukti-bukti palsu agar } \\
\text { publik terkecoh. }\end{array}$ \\
\hline 7 & $\begin{array}{l}\text { Bandwagon } \\
\text { (gerobak musik) }\end{array}$ & $\begin{array}{l}\text { Mendorong dan mengajak khalayak untuk bersama-sama } \\
\text { orang banyak bergerak atau menyetujui suatu gagasan } \\
\text { atau program, dengan mengatakan bahwa telah banyak } \\
\text { yang menyetujui. Mengembar-gemborkan sukses yang } \\
\text { dicapai seseorang, suatu lembaga atau organisasi. Dalam } \\
\text { bidang ekonomi teknik ini untuk menarik minat pembeli. }\end{array}$ \\
\hline 8 & $\begin{array}{l}\text { Downrigth Lying } \\
\text { (sungguh-sungguh } \\
\text { berbohong) }\end{array}$ & $\begin{array}{l}\text { Guna mencapai tujuan propagandis, tidak segan-segan } \\
\text { untuk menciptakan suatu fakta palsu dan benar-benar } \\
\text { sebuah kebohongan, hanya demi mewujudkan apa yang } \\
\text { diinginkannya melakukan pembohongan publik. }\end{array}$ \\
\hline 9 & $\begin{array}{l}\text { Repitition } \\
\text { (pengulangan) }\end{array}$ & $\begin{array}{l}\text { Propagandis yakin bahwa bila suatu pernyataan cukup } \\
\text { banyak diulang-ulang, pada waktunya akan diterima } \\
\text { oleh orang banyak, variasi dari teknik ini adalah } \\
\text { penggunaan slogan dan kata kunci. }\end{array}$ \\
\hline 10 & $\begin{array}{l}\text { Assertion } \\
\text { (penonjolan) }\end{array}$ & $\begin{array}{l}\text { Propagandis jarang membantah sesuatu hal, tapi } \\
\text { menciptakan seuatu pernyataan tegas atau penonjolan } \\
\text { (assertion) yang tangguh yang mendukung pendapatnya. } \\
\text { Dapat dilihat dari cara-cara propaganda yang menyajikan } \\
\text { hanya satu sisi dari gambaran keadaan, suatu } \\
\text { pembatasan yang disengaja terhadap pemikiran bebas. }\end{array}$ \\
\hline 11 & Emotional Streotype & $\begin{array}{l}\text { Menumbuhkan rasa curiga yang penuh emosi, contoh } \\
\text { Presiden A bisa menang karena ada kecurangan, } \\
\text { memberikan penanaman kepercayaan yang bersifat } \\
\text { negative karena stereotype terakait etnis, agama dan } \\
\text { keterunan. }\end{array}$ \\
\hline 12 & $\begin{array}{l}\text { Using all form of } \\
\text { persuation } \\
\text { (penggunaan teknik } \\
\text { persuasi) }\end{array}$ & $\begin{array}{l}\text { Penggunaan teknik persuasi dengan memilih kata-kata } \\
\text { yang bisa menarik perhatian seseorang sehingga orang } \\
\text { mau mengikuti kehendak propagandis. Teknik yang } \\
\text { digunakan dengan membujuk, rayuan, himbauan dan } \\
\text { 'iming-iming'. Terjadi dalam pidato kampanye pemilu, } \\
\text { agar mendapat simpati dan dipilih, digunakanlah janji- } \\
\text { janji seperti bila terpilih maka pendidikan gratis, jalan } \\
\text { diperbaiki, dsb. }\end{array}$ \\
\hline 13 & $\begin{array}{l}\text { Reputable } \\
\text { Mounthpiece } \\
\text { (mengedepankan reputasi, } \\
\text { selalu cari muka) }\end{array}$ & $\begin{array}{l}\text { Teknik yang dilakukan dengan mengemukakan sesuatu } \\
\text { yang tidak sesuai kenyataan. Teknik ini biasaya } \\
\text { digunakan oleh propagandis dengan menyanjung } \\
\text { pemimpin, akan tetapi tidak tulus. Ada ambisi seseorang } \\
\text { atau sekelompok yang ingin aman di lingkaran } \\
\text { kekuasaan. Mencari jalan aman agar selalu aman dari } \\
\text { kritik dan evaluasi, kadang hanya mengemukakan yang } \\
\text { baik-baik saja. Sehingga pemimpin jadi lupa diri dan } \\
\text { tidak objektif. }\end{array}$ \\
\hline 14 & $\begin{array}{l}\text { Situation Tyrannized } \\
\text { (situasi di dzalimi) }\end{array}$ & $\begin{array}{l}\text { Momentum yang terjadi karena perbedaan pandangan, } \\
\text { membuat pejabat atau elite tertentu diberhentikan atau } \\
\text { dicopot dari jabatannya. Terkesan di zalimi, sehingga } \\
\text { menarik simpati khayalak. Dengan pemanafaatan opini } \\
\text { publik seorang propagandis akan menggunakanya untuk } \\
\text { mendapatkan dukungan publik yang berempati. }\end{array}$ \\
\hline
\end{tabular}




\section{iv. Kampanye}

Menurut Michael Pfau dan Roxanne Parrot (1993) ${ }^{50}$, menggungkapkan bahwa, Campaigns are inherently persuasive communication ativities, yang artinya segala aktivitas kampanye tersebut selalu melekat dengan kegiatan komunikasi persuasif (komunisuasif). Selanjutnya Pfau dan Parrot mendefinisikan, "A Campaign is conscious, sustained and incremental process designed to be implemented over a specified periode of time for the purpose of influencing a specified audience", yang artinya, bahwa suatu kampanye yang secara sadar, menunjang dan meningkatkan proses pelaksanakan yang terencana pada periode tertentu untuk bertujuan mempengaruhi khalayak sasaran terentu. ${ }^{51}$ Istilah kampanye baru dikenal secara luas sejak tahun 1940-an dengan pengertian campaign is generally exemply perusuasion (kampanye secara umum menampilkan suatu kegiatan yang bertitik tolak untuk membujuk).

Istilah propaganda sudah lebih dahulu populer karena belum masuknya suatu era yang beriklim demokrasi. Propaganda terjadi di era otorier dimana komunikator memberikan pesan hanya satu arah, kursif, dan intimidasi melalui kekuatan dan kekuasaan yang dimiliki pihak komunikator, biasanya berkonotasi negatif terhadap khalayaknya. Kegiatan komunikasi propaganda dirancang untuk jangka panjang biasanya berkaitan dengan masalah sosial, keagamaan, politik, budaya dan militer. ${ }^{52}$ Selanjutnya Rosady Ruslan $^{53}$ menjelaskan kampanye merupakan konsep yang lahir kemudian setelah era propaganda, kampanye merupakan kegiatan komunikasi secara terencana yang lebih moderat, terbuka, toleran, dengan waktu terbatas atau jangka pendek dan program jelas, persuasif serta dapat diidentifikasikan secara jelas nara sumbernya (komunikator) dan selalu berkonotasi positif. Disimpulkan oleh Ruslan ${ }^{54}$ dari beberapa pakar mengenai kampanye adalah kampanye terdapat kegiatan-kegiatan:

1) Adanya aktivitas proses komunikasi kampanye untuk mempengaruhi khalayak tertentu.

2) Untuk membujuk dan memotivasi khalayak untuk berpartisipatif.

3) Ingin menciptakan efek atau dampak tertentu seperti yang direncanakan.

\footnotetext{
50 Dalam Rosady Ruslan. Kiat dan Strategi Kampanye Public Relations. Jakarta: PT. Raja Grafindo Persada, 2005, HIm. 26

${ }^{51}$ Ibid. hlm. 23

52 Ibid. hlm. 22-23

53 Ibid. hlm. 22

54 Ibid. hlm. 24
} 
4) Dilaksanakan dengan tema spesifik dan nara sumber yang sumber.

5) Dalam waktu tertentu atau telah ditetapkan (terjadwal sesuai peraturan dan Undang-Undang), dilaksanakan secara terorganisasi dan terencana baik untuk kepentingan kedua belah pihak atau sepihak. Karena kampanye harus sesuai waktu atau jadwal yang telah ditentukan, bisa jadi ada bentuk kampanye terselubung di dalam publikasi atau iklan politik bila diselenggarakan diluar waktu yang telah ditentukan.

Tabel 4.3: Perbedaan Umum Kampanye dan Propaganda (sumber: Ruslan, 2005: 24)

\begin{tabular}{|ll|l|l|}
\hline \multicolumn{2}{|c|}{ Keterangan } & \multicolumn{1}{|c|}{ Kampanye } & \multicolumn{1}{c|}{ Propaganda } \\
\hline 1. & Nara Sumber dan Tema & Dapat diidentifikasikan & Tidak jelas dan tersembunyi \\
\hline 2. Periode & Waktu yang terbatas & Tidak terikat dengan waktu \\
\hline 3. & Sifat Gagasan & Moderat dan terbuka & Tertutup dan memaksakan \\
\hline 4. & Tujuan Kegiatan & Spesifik dan variatif & $\begin{array}{l}\text { Umumnya dan untuk } \\
\text { mengubah sistem atau nilai- } \\
\text { nilai kepercayaan. }\end{array}$ \\
\hline 5. $\quad$ Penerimaan & Sukarela dan persuasif & $\begin{array}{l}\text { Dipaksakan, kursif dan } \\
\text { menekan bahkan diikuti } \\
\text { dengan ancaman }\end{array}$ \\
\hline 6. $\quad$ Modus Pelasanaan & Sesuai kode etik & Tanpa aturan main yang jelas \\
\hline 7. $\quad$ Kepentingan (untuk) & Kedua belah pihak & $\begin{array}{l}\text { Sepihak, dan khusus } \\
\text { kepentingan penguasa, } \\
\text { militer, hukum, politik }\end{array}$ \\
\hline 8. $\quad$ Penilaian Publik & Berkonotasi positif & Konotasi negatif \\
\hline
\end{tabular}

Kampanye juga ada yang bertujuan menyerang kandidat lain yang menjadi lawan politik. Kampanye tersebut bisa berbentuk kampanye hitam (black campaign) yang biasanya merupakan berita non fakta atau rekayasa dan juga ada kampanye negatif (negative campaign) yang berusaha menggali, mencari, menyelidiki sekecil apapun kelemahan atau kekurangan lawan politik yang akan dijadikan senjata untuk menjatuhkan atau membunuh karakter lawannya. Terkait kegiatan tersebut ada peran yang dengan istilah "Spin Doctor", Hafied Cangara ${ }^{55}$ mengutip Louw (dalam Handayani, 2005) menjelaskan spin doctor lebih dikenal dengan konsultan public relations politik yang bertugas membangun image (citra) politik bagi seorang politikus, dilain pihak dimaksudkan memberikan kesan yang negatif pada saingannya. Graber $^{56}$ juga menyatakan spin doctor adalah individu yang memiliki kemampuan menguasai publik, menggerakkan massa dan menguasai media sekaligus sebagai konseptor politik yang bertujuan memengaruhi. Posisi spin

\footnotetext{
${ }^{55}$ Hafied Cangara, Komunikasi Politik: Konsep, Teori dan Strategi, Jakarta: Rajawali Pers, 2011, hlm. 230

${ }^{56}$ Ibid.
} 
doctor berada diantara politikus dan media. Profesi ini memiliki kemampuan dibidang komunikasi yang menggabungkan prinsip-prinsip public relations, periklanan dan pemasaran politik. Public Relations politik dapat dikatakan sebagai bagian dari propaganda alasannya karena adanya pesan yang direncanakan bahkan di rancang sedemikian rupa (spin doctor). Sebagai contoh pada kampanye pemilihan presiden Amerika tahun 20016, ada dugaan plagiat pidato istri Donald Trumph kandidat presiden dari partai Republik, Melania Trumph menjiplak pidato Michael Obama empat tahun silam. Ternyata naskah pidato memang dirancang oleh tim kampanye jadi bukan murni dari gagasan, inspirasi dan keinginan yang ada di dalam hati (niat). Propaganda menjadi istilah yang terkesan negatif karena pada masa perang dunia I dan II, propaganda menjadi cara yang efektif bagi penguasa untuk mengerakkan rakyatnya agar mendukung perang. padahal propaganda bisa bersifat positif dan transparan (putih) dengan menyebutkan sumber pengirim pesan yang digunakan untuk misi sosial misalnya gerakan penghijauan atau bisa menjadi negatif bila tidak jelas sumber pengirim pesannya (abu-abu) dan juga bisa bersifat menyerang lawan politik (hitam), tergantung dari niat atau motif sang komunikatornya.

\section{Pembicaraan Politik}

Pesan politik dapat berupa bahasa, simbol, dan persuasi. Ketiga bentuk ini akan saling mengkombinasikan dalam penyampain pesan pada proses pembicaraan (conversation) politik baik secara linear, interaksional dan transaksional. Makna komunikasi politik menurut Astrid S. Susanto ${ }^{57}$ adalah komunikasi yang diarahkan kepada pencapaian suatu pengaruh sedemikian rupa, sehingga masalah yang dibahas oleh jenis kegiatan komunikasi ini dapat mengikat semua warganya melalui suatu sanksi yang ditentukan bersama oleh lembaga-lembaga politik. Komunikasi politik memiliki 3 pola orientasi, yaitu: 1) Orientasi pada kekuasaan, 2) Orientasi pada otoritas, 3) Oritenasi pada pengaruh.

Berbicara adalah kegiatan menyampaikan pesan dalam bentuk lambang-lambang bahasa ujar. Penelitian yang dilakukan Goodglass dan Bumstein (1973) ${ }^{58}$ menghasilkan suatu penjelasan bahwa gerak gerik mulut, bibir, lidah dan rahang serta alat ucap lainnya berbicara atau bukan berbicara. Manusia dapat berbicara karena dilengkapi dengan otak dan alat-alat laryngobuccal. Sehingga kerja sama kedua alat itu menghasilkan suara yang dapat ditangkap dan mengundang makna, apa yang keluar dari proses mental internal, yang disebut berpikir dan berlangsung di dalam diri manusia. Santo Gregorius menyatakan bahwa karena manusia dapat berbicra dengan lidahnya serta memberikan isyarat dengan tangannya, maka ia melebihi dari

\footnotetext{
${ }^{57}$ Astrid S. Susanto, Komunikasi Sosial di Indonesia, Bandung: Percetakan Binacipta, 1985, hlm. 1

${ }^{58}$ Paisak, OP, Cit, hlm. 148
} 
mahluk lainnya seperti binatang. Karena kemampuan berbicara tersebut maka munculkan istilah "bersilat lidah", atau terbentuklah filosofi atau filsafat yang dikonstruksi perpaduan kerja otak dan lidah manusia. Lidah adalah alat berbicara yang terpenting, dalam ilmu fonetik arikulator, satu bidang dalam ilmu bahasa (linguistic), lidah memiliki keistimewaan dalam pembentukan huruf, termasuk menjadi ciri khas sebuah bahasa. Penelitian Robin (1992) memperlihatkan dengan alat-alat bicara lain, seperti uvula (anak tekak), palatum mole (langit-langit lembut), palatum durum (langit-langit keras), ging giva (gusi) dan gigi depan atas. ${ }^{59}$ Bila ada yang tidak pas atau tidak sesuai persentuhan lidah dengan bagian-bagian pembentuk bunyi di daerah mulut maka bisa menyebabkan bunyi atau suara yang berbeda sehingga tidak atau sulit dimengerti oleh lawan bicara kita. Berpolitik otomatis salah satu nya adalah mengandalkan kemampuan berbicara dalam menyampaikan dan memperjuangkan ide dan gagasannya. Pada saat ada lawan bicara yang membahasan pesan politik dan terjadi komunikasi intraksional sampai tahap transaksional itulah yang dinamakan pembicaraan politik.

Pembicaraan politik sendiri bisa bermakna komunikasi yang terjadi diantara para pemimpin atau komunikator politik (seperti: Politikus, profesional, pejabat, atau warga negara yang aktif), dengan perannya sebagai komunikator politik maka mereka akan berbicara persoalan politik. Adapun komunikator politik merujuk pada Politikus, profesional seperti juru bicara, pejabat, dan warga negara yang aktif menyampaikan kritik terhadap pelayanan negara kepada warganya. Dengan kata lain, disebut sebagai komunikator politik karena yang bersangkutan berbicara tentang politik. Politik sendiri bukan hanya soal kekuasaan, tapi juga membahas masalah kewenangan, kebijaksanaan, contohnya aksi protes atau mengkritisi layanan kesehatan atau kinerja pemerintahan pun termasuk dalam isu pembicaraan politik. Bagi komunikator politik adalah, "siapa" yang "mengatakan apa" (says what), dalam pembahasan ini adalah komunikasi dalam konteks politik. Jadi proses "mengatakan apa" berisi mengenai pembicaraan politik. Pembicaraan politik adalah pembicaraan segala hal yang menyangkut masalah hubungan baik vertikal, contoh antara pejabat kepada bawahan, kepada masyarakat atau warga (masalah kebijakan), kepada konstituen (masa pemilu), dan secara horizontal, yaitu pembicaraan kepada sesama Politikus, pejabat, dan lawan politiknya.

Bagaimana hubungan antara kata dan permainan kata dengan politik? Kata merupakan alat politik. Umumnya, Politikus banyak bermain dengan kata yang umumnya ambigu dan multitafsir. Permainan kata ini sangat luar biasa di Indonesia dan seringkali membiaskan permasalahan politik yang sedang hangat dibicarakan. Apa saja guna pembicaraan politik? Pembicaraan politik berguna untuk memberdayakan elemen-elemen negara untuk memberikan pelayanan maksimal pada warga negara. Dalam kehidupan sehari-hari, pembicaraan politik yang dilakukan para politikus, baik itu

\footnotetext{
${ }^{59}$ Ibid. hlm. 148
} 
pejabat maupun yang berusaha menjadi pejabat, merupakan aspek yang sangat penting. Kebanyakan di antara kita mengenal seseorang sosok politik dari pembicaraannya seperti dalam konferensi pers, pidato, dan pernyataan tertulis atau karena apa yang orang katakan tentang dia. Sehingga, pembicaraan politik merupakan titik terbangunnya citra seseorang politikus.

Melalui pembicaraan politik, seorang jurnalis politik mampu menelaah setiap kata untuk mencari nuansa sindiran atau petunjuk tentang apa yang akan terjadi. Para jurnalis televisi, surat kabar, dan majalah menelaah setiap kata untuk mencari makna atau simbol-simbol yang tersirat dari para politikus. Bisa juga berupa pesan sindiran, atau petunjuk tentang apa yang akan terjadi. Masyarakat umum bisa terus mencermati dan menjadikan diskusi, perdebatan, obrolan di warung kopi sampai menjadi viral di dunia maya. Opini pun bermunculan dan terus berkembang bahkan bisa menjadi sign (tanda) arah dari arus pergerakan proses politik berdasarkan pembicaraan para elit politik terutama yang terekpos oleh media massa dan menjadi tranding topic atau viral60 di dunia maya. Dalam hal ini, politik menarik karena ada nuansa "tebak-tebakan", penuh teka-teki (unpredictable), semua merupakan ranah yang dinamis dan penuh peristiwa kejutan, hanya dua kata kunci abadi dalam politik, yaitu 'kepentingan' dan 'kekuasaan'. Jurnalis politik akan terus memburu dan mengangkat peristiwa terutama yang kontroversial, bersumber dari pembicaraan politik lalu di kemas menjadi sebuah berita. Menurut David VJ Bell (1975)61, ada 3 (Dan Nimmo melengkapi menjadi 4) jenis pembicaraan yang mempunyai kepentingan politik, yaitu:

\section{a. Pembicaraan Kekuasaan}

Pembicaraan kekuasaan mempengaruhi orang lain dengan ancaman atau janji. Bentuk pernyataannya adalah : "Jika anda melakukan $X$, maka saya akan melakukan $Y^{\prime \prime}$. Di sini " $X$ " adalah sikap orang lain yang diinginkan oleh pembicara, "Y" adalah maksud yang dinyatakan untuk memberikan lebih banyak (janji) atau lebih sedikit (ancaman) sehingga menimbulkan rasa puas atau sesuatu yang dinikmati bila sikap itu dilakukan. Pembicaraan kekuasaan cenderung terjadi diantara orang yang kuat untuk mengancam yang lemah dalam segala hal (fisik, kekayaan materi (uang), keturunan, dan lain sebagainya). Pembicaraan ini bisa juga dalam bentuk penyuapan, pemerasan jadi kekuasaan adalah sebuah kekuatan atau kemampuan untuk memanipulasi sanksi positif atau negatif. Contoh : misalnya ada pejabat atau

60 Viral: bisa jadi berasal dari kata 'Virus', bibit penyakit yang sifatnya menyebar, menurut kamus Cambridge: kata viral digunakan untuk menggambarkan sesuatu yang cepat menjadi sangat populer atau dikenal oleh dipublikasikan di internet atau dikirim dari orang ke orang melalui email, telepon, sosial media, aplikasi smartphone (BlackBarry Massenger, Whatsup, Facebook, twitter, Instagram, dan lainnya). Sumber: http://dictionary.cambridge.org/dictionary/english/viral

${ }^{61}$ Nimmo, OP, Cit, hlm. 75 
penguasa yang mengatakan, "bila warga yang ada di daerah penggusuran tidak mau pergi dalam waktu 2 × 24 jam, maka kami akan melakukan penggusuran dengan paksa". Bisa juga pembicaraan kekuasaan, digunakan untuk mengancam hal-hal yang membahayakan negara.

\section{b. Pembicaraan Pengaruh}

Kata-kata yang terdapat dalam pembicaraan pengaruh adalah yang bernada dorongan, nasehat, bujukan, permintaan, dan peringatan. Bentuk pernyataanya adalah: "Jika anda melakukan $X$, maka anda akan melakukan, merasa, mengalami $Y^{\prime \prime}$. Komunikasi memberi pengaruh karena prestise atau reputasinya lalu memanipulasi persepsi atau pengharapan orang terhadap kemungkinan mendapatkan untung atau rugi. Pembicaraan pengaruh mensyaratkan kompromi atau bisa terjadi pilihan iya atau tidak. Contoh dalam kalimat: "kenaikan harga bahan bakar minyak (BBM) adalah untuk kepentingan kita juga, yaitu adanya pengalihan kepada pembangunan insfrastruktur yang akan dirasakan oleh kita dan juga anak-anak kita".

\section{c. Pembicaraan Otoritas}

Pembicaraan otoritas adalah pemberian perintah tanpa syarat-syarat atau argumentasi lainnya. Bentuk pernyataanya adalah: "Lakukan $X^{\prime}$ atau "Dilarang melakukan $X^{\prime}$. Pembicaraan atau pernyataan otoritas, misalnya dengan kata-kata "Lakukan!" atau "Dilarang!". Pembicaraan ini akan muncul dari seorang penguasa yang sah, yaitu memiliki suara otoritas dan memiliki hak untuk dipatuhi. Komunikator-nya adalah seorang pemimpin yang disegani karena kharismatik, keyakinan, adat istiadat atau karena jabatan resmi (legal) pada suatu lembaga pemerintahan. Pembicaraan otoritas, mengharuskan tindakan tegas, karena kewenangannya yang penuh. Maka bila ada pemimpin yang sudah memiliki otoritas tapi tidak berani mengambil sikap menunjukkan ada yang salah dalam kepemimpinannya.

\section{d. Pembicaraan konflik.}

Konflik adalah perbedaan pendapat, persaingan dan pertentangan diantara sejumlah individu, kelompok atau organisasi dalam upaya mendapatkan atau mempertahankan sumber-sumber dari keputusan yang dibuat dann dilaksanakan pemerintah (penguasa). Penyebab terjadinya konflik adalah adanya benturan kepentingan, baik yang bersifat horizontal (antara masyarakat dengan masyarakat) atau yang bersifat vertical (masyarakat dengan pemerintah). Melalui pembicaraan konflik, para komunikator politik menyelesaikan perselisihan-perselisihan mereka dengan 
menyusun perbendaharaan kata tentang asumsi, makna, pengharapan dan komitmen bersama.

Berdasarkan strukturnya ada dua jenis konflik, yaitu: ${ }^{62}$ 1) Konfllik menang-kalah (zero-sum conflict), dan 2) Konflik menang-menang (non-zerosum conflict). Konflik kalah menang terjadi dimana situasi konflik yang bersifat antogonistik (berlawanan), sehingga tidak memungkinkan tercapainya kompromi di antara pihak-pihak yang berkonflik. Lalu konflik menang-menang adalah situasi konflik dimana pihak-pihak yang berkonflik masih mungkin mengadakan suatu kompromi dan kerjasama sehingga semua pihak akan mendapatkan bagian dari konflik itu.

Konflik tidak mungkin terhindarkan dalam dunia politik, perbedaan kepentingan dan ideologi cara pandang akan selalu terjadi. Solusi dari kondisi tersebut adalah bagaimana mengelola konflik (management conflict) tersebut agar menjadi sesuatu yang bernilai positif demi keutuhan nusa dan bangsa. Pengelolaan atau pengaturan konflik ada tiga bentuk, yaitu: ${ }^{63}$

a. Konsiliasi, yaitu pengaturan konflik melalui model parlemen atau kuasi-parlemen di mana semua pihak berdiskusi secara terbuka untuk mencari kesepakatan tanpa ada pihak-pihak yang memonopoli pembicaraan atau memaksakan kehendak.

b. Mediasi, yaitu kedua pihak sepakat mencari nasehat dari pihak ketiga (seorang mediator berupa tokoh atau lembaga tertentu yang diakui), tetapi nasehat dari mediator tidak mengikat mereka.

c. Arbitrasi, yaitu kedua pihak sepakat untuk mendapatkan keputusan akhir yang bersifat legal kepada pihak ketiga (arbitrator), misalnya pengadilan.

Selanjutnya tentu potensi konflik terjadi diantara partai politik yang bersaing dalam rangka memperebutkan atau mempertahankan kekuasaannya. Lalu bagaimana pengaturan yang kerap terjadi diantara kepentingan partai politik? Pertama, dilakukan koalisi pemerintah yang stabil di antara partaipartai politik. Tentunya akan akan memunculkan kekuatan partai oposisi yang secara otomatis berperan sebagai pengontrol, pengawasan atau pengkritisi pemerintah. Kedua, diterapkan prinsip proporsionalitas, yaitu posisi-posisi pemerintahan yang penting didistribusikan kepada partai-partai politik sesuai dengan proporsi jumlahnya dalam keseluruhan penduduk. Ketiga, diterapkan sistem saling-veto, yaitu suatu keputusan politik tidak akan diputuskan tanpa disetujui oleh semua partai politik yang berkonflik.

\footnotetext{
${ }^{62}$ Umaruddin Masdar, dkk, Mengasah Naluri Publik Memahami Nalar Politik, Yogyakarta: LKiS, 1999, hlm. 105-106

63 Ibid.
} 


\section{c. Saluran Komunikasi Politik}

Saluran yang akan digunakan dalam berkomunikasi politik tergantung pada format (bentuk) pesan dan motif (tujuan) dari pengirim pesan (komunikator). Menurut Hafied Cangara ${ }^{64}$ Saluran komunikasi politik adalah alat serta sarana yang memudahkan komunikator politik penyampaian pesan politiknya kepada komunikan. Pesan di sini bisa dalam bentuk lambanglambang pembicaraan seperti kata, gambar, gesture (gerak-gerik tubuh) atau aksi (tindakan), bahkan diam pun bisa merupakan sebuah pesan. Pesan politik bisa juga dengan menggunakan kombinasi lambang, foto, kata-kata sehingga menghasilkan sebuah cerita. Disamping penggunaan media atau alat mekanis, teknik, dan sarana untuk saling bertukar lambang, namun manusia pun sesungguhnya bisa dijadikan sebagai saluran komunikasi. Jadi, lebih tepatnya saluran komunikasi itu adalah pengertian bersama tentang siapa dapat berbicara kepada siapa, mengenai apa, dalam keadaan bagaimana, sejauh mana dapat dipercaya. Saluran yang digunakan adalah mulai dari antar personal, komunikasi kelompok, struktur organisasional, komunikasi massa dan yang terkini adalah penggunaan media baru (media sosial) yang menjadi sarana atau jembatan dimana pesan komunikasi politik disalurkan.

\section{Antar personal}

komunikasi langsung yaitu face to face dan door to door dalam bentuk lobi-lobi politik dan retorika negosiasi (one to one). Membutuhkan ruang yang lebih personal karena bertujuan mempersuasi lebih dalam untuk terjadinya dialog, negosiasi, dan kompromi yang tidak mungkin dilakukan di ruang publik, seperti ruang sidang terbuka, di ruang rapat, dan seterusnya. Komunikasi antarpersonal bisa dimulai melalui percakapan melalui telepon (seluler atau fixed line) atau dengan mengirim short message service (SMS) kepada orang yang dituju dan selanjutnya dilanjutkan dengan tatap muka langsung. Dengan berbicara satu sama lain, masyarakat mengungkapkan pandangan masing-masing (bisa sepakat atau tidak sepakat) dan menciptakan common universe of discourse 65 , sehingga dapat mengatur tindakan bersama yang menjadi dasar bersama (groundwork) dalam konteks perbedaan-perbedaan. Saluran komunikasi politik melalui antarpersonal (antarpribadi) mengandalkan bahasa dan seni berbicara atau yang disebut retorika. Retorika adalah komunikasi dua arah diantara dua orang atau lebih dimana masing-masing akan saling mempengaruhi pandangan, keyakinan dan terutama sikap dengan pola resiprokal (timbal-balik).

\footnotetext{
${ }^{64}$ Cangara, OP, Cit, hlm. 32

${ }^{65}$ Nasution, OP, Cit, hlm. 116
} 
Retorika berperan pada saat mempersuasi secara antarpersonal yang inheren di antara para komunikator politik. Retorika juga dilakukan pada komunikasi di hadapan publik umum dalam bentuk pidato yang sasarannya terjadi persuasi dengan pola one to one yang diwujudkan dengan dialog dan negosiasi, yaitu bertujuan mempengaruhi tiap pribadi individu yang ada diantara publik sehingga mengambil sikap secara personal tanpa dipengaruhi oleh orang disekitarnya atau sejumlah kelompok besar. Sebagai contoh dalam pidato kampanye kandidat menyampaikan pidato untuk mempersuasi massa dihadapannya dan terjadi proses penerimaan pesan oleh pendengar yang secara otomatis terjadi negosiasi secara kognitif, afektif sampai tahap konatif (tindakan/ sikap) misalnya menyetujui (sepaham) atau tidak menyetujui (menolak) dengan pembicara secara individu walaupun dia diantara banyak orang yang mungkin setuju atau tidak setuju dengan pembicara.

Seni berbicara akan dilakukan dalam rangka menarik minat khayalak. Menurut Zulkarimen Nasution ${ }^{66}$, pidato merupakan suatu konsep penting dalam menganalisis retorika sebagai suatu identifikasi atau simbolisme (antara pembicara dan pendengar). Pidato adalah suatu pembicaraan negosiasi dan juga sautu proses kreatif untuk membangun pengertian bersama yang didalamnya ada kata-kata, simbol-simbol, definisi situasi, visi dan misi, pertentangan, berbagi posisi dalam perdebatan, dan pengungkapan identitas masing-masing, sehingga terjadi konsensus (pertujuan bersama). Retorika akan menciptakan negosiasi yang akan berlangsung terus-menerus.

\section{Struktur masyarakat dan organisasi}

Saluran komunikasi politik melalui stuktur pada masyarakat dan organisasi merupakan saluran dengan pola propaganda, agitasi, komunikasi dua tahap (two flow step communication). Pribadi-pribadi orang dalam suatu kelompok akan mudah dikendalikan melalui peran tokoh-tokoh penting yang ada di dalamnya. Propaganda sebagai pengendalian sosial melalui tokoh karismatik, atau pemimpin organisasi yang mempunyai kekuatan untuk mengarahkan anggota dan pengikutnya. Komunikator politik akan membangun komunikasi dengan pola komunikasi dua tahap (two flow step communication) melalui pemimpin pendapat (opinion leader). Rogers dan Shoemaker (1971)67 menggambarkan pada para pemimpin opini sebagai "pribadi-pribadi tertentu yang memiliki kemampuan mempengaruhi orang lain dalam perilaku opini (opinion behavior) melalui cara-cara atau jalan yang disukai oleh orang-orang yang dipengaruhi tersebut". Selanjutnya Zulkarimen Nasution ${ }^{68}$ menjelaskan bahwa hasil studi mengenai prilaku politik masyarakat Amerika Serikat pada masa pemilihan presiden tahun 1940 dari tokoh komunikasi

\footnotetext{
${ }^{66}$ Ibid.

${ }^{67}$ Nasution, OP, Cit, hlm. 98

68 Ibid.
} 
Lazarsfeld (1962) menyimpulkan ternyata tidak seorang pun pemilih yang secara langsung terpengaruh oleh media massa dalam menentukan pilihan masing-masing. Yang terjadi sesungguhnya adalah masyarakat menentukan pilihan setelah mendapat "pengaruh" dari orang-orang yang disebut sebagai pemimpin opini. Pengaruh bisa dalam bentuk personality, informasi, gagasan, persuasi, nasehat, dan interpretasi dari masalah yang terkait.

Tokoh-tokoh bisa merupakan tokoh organisasi massa (ORMAS) yang besar, struktur Partai Politik mulai dari Dewan Pimpinan Pusat (DPP), wilayah (DPW), daerah (DPD) sampai pimpinan ranting (DPC) dan cabang (DPAC), pimpinan perusahaan, bahkan bisa jadi ada pejabat pemerintah yang menggunakan jabatannya untuk mempengaruhi bawahannya dan seterusnya. Saluran komunikasi kelompok; komunitas-komunitas, organisasi profesi, ikatan alumni, organisasi sosial keagamaan, paguyuban, kelompok suku (adat), karang taruna, kelompok pengajian, kelompok pengajian, kelompok tani dan nelayan, koperasi, persatuan olahraga, kerukunan keluarga, perhimpunan hobi. Saluran Komunikasi Publik; aula, balai desa, pameran, alun-alun, panggung kesenian, pasar, swalayan (supermarket, mall, plaza), sekolah, kampus. Saluran Komunikasi Sosial, misalnya pesta perkawinan, arisan, acara sunatan, pertunjukan musik, santunan yatimpiyatu, pertunjukan wayang, pesta rakyat, dan lain-lain.

\section{Media massa}

Media massa terdiri dari media cetak dan elektronik. Dalam komunikasi politik media massa digunakan untuk upaya publikasi, penyebaran iklan politik, propaganda, dan agitasi politik. Media massa akan menjangkau khalayak secara cepat, heterogen dan searah (linear). Misalnya media cetak, yaitu surat kabar, tabloid, majalah, buku. Media elektronik dalam bentuk film, radio, televisi, video berbentuk DVD. Namun, penggunaan media massa untuk iklan politik sejak era Reformasi sangat sering digunakan. Terutama politikus yang bermodal besar, karena biaya yang sangat mahal untuk memasang iklan di media massa, terutama di stasiun televisi. Bisa dikatakan sebagai alat untuk propaganda bagi politikus rangkap pengusaha apalagi sebagai pemilik media tersebut. Iklan politik sebagai alat propaganda halus yang esensinya adalah sebuah kampanye terselubung. Undang-Undang mengatur kapan saat-saat dibolehkan berkampanye melalui media massa.

Lalu bisa juga menggunakan sarana media cetak dalam bentuk leaflet, brosur, selebaran, stiker, bulletin yang biasanya dibagikan kepada masyarakat baik dalam forum pertemuan dan secara langsung. Media Luar ruang (outdoor media); baliho, spanduk, papan reklame, bendera, kerudung, pin, logo, topi, rompi, kaos oblong, iklan di mobil, kalender, pulpen, gantungan kunci, payung, berbagai bentuk souvenier dan apa saja yang bisa 
digunakan untuk mempublikasikan diri kandidat atau upaya politikus meningkatkan popularitasnya di masyarakat.

\section{Media baru}

Perkembangan teknologi terkini adalah pesatnya penggunaan komputer dan jaringan di dunia maya (internet), dimana koneksitas antar individu, kelompok, organisasi bahkan aktifitas negara terintegrasi dalam jaringan virtual. Ruang publik sudah bergeser ke ruang virtual yang lebih luas dan lebih independen karakteristiknya. Mulai dari anak Sekolah Dasar (SD) sampai ibu rumah tangga merupakan pengguna teknologi media. Baik itu teknologi media elektronik, radio, televisi, maupun media sosial. Media sosial digunakan di semua kalangan, dan penyebaran pesan menggunakan media sosial di nilai sangat cepat, karena menggunakan teknologi modern. Tak lain halnya seperti para komunikator politik. Ia menggunakan berbagai media sosial untuk memudahkan penyampaian pesan politik mereka ke komunikan dan merekapun langsung dapat segera mendapatkan respon atau feedback berupa like (suka) atau coment (komentar) dari netizen.

Saat ini media yang lebih dipilih oleh komunikator politik lebih cenderung menggunakan media sosial. Seperti halnya, facebook, twitter, instagram, youtube, dan lain-lain. Hal ini karena komunikator politik lebih leluasa menyampaikan pesan politik yang akan disampaikan daripada menggunakan media tradisional lainnya. Komunikator (aktor) politik seperti Susilo Bambang Yudhoyono intens menggunakan media sosial dalam menyampaikan pesan politiknya. Seperti halnya ia mengunggah video ucapan selamat kepada menteri-menteri yang baru saja dilantik oleh Presiden Joko Widodo pada 27 Juli 2016. Ia juga mengucapkan terima kasih kepada menteri-menteri yang di copot jabatannya dari kabinet kerja Joko Widodo seperti Rizal Ramli.

Dalam video yang di unggahnya pada, 28 Juli 2016 pukul 00.24 di facebook ${ }^{69}$ dengan judul "SBY Today: Selamat Bertugas $\mathcal{E}$ Sukses bagi Para Menteri Baru" video tersebut di lihat sebanyak 87.000 orang, di sukai 10.000 orang diakses 30 juli 2016 pukul 06.20 WIB. Ini merupakan suatu bukti bahwa dalam waktu sebentar saja orang sudah puluhan ribu orang melihat video tersebut. Bahkan media meinstraim seperti Metrotvnews mengambil judul berita "Rizal Ramli Didepak, SBY: Percayalah Sejarah Mencatat Pengabdian Kepada Bangsa". Dalam berita tersebut juga metrotvnews.com menyampaikan kalau mereka hanya melihat dari video yang di unggah SBY Twitter @SBYudhoyono, Kamis (28/7/2017). Beegitupun republika.co memberi judul "SBY ucapkan terima kasih kepada Rizal Ramli, Ada Apa?". Dalam berita

${ }^{69}$ Fan Page Facebook Susilo Bambang Yudhoyono mentautkan link Youtube dari Channel SBY: https://www.youtube.com/wacht?v=6 6q9YtVMvE 
republika pun menyatakan kalau mereka tidak mewawancarai langsung SBY akan tetapi mereka hanya mengutip ucapan SBY dari akun Youtube pribadi SBY. Begitupula dengan media-media lainnya. Dalam hal tersebut bisa disimpulkan kalau aktor politik seperti SBY sebagai ketua partai Demokrat sekaligus mantan Presiden RI memakai media sosial sebagai media komunikasi untuk menyampaikan pesan politik lebih efektif dan praktis, tanpa harus membuat konferensi pers secara khusus dan mengundang banyak wartawan.

\section{d. Khalayak dan Efek Komunikasi Politik}

Khalayak adalah penerima pesan, biasa disebut komunikan, receiver. Khalayak komunikasi politik juga bisa dikatakan dipengaruhi faktor lingkungan dan budaya dimana khalayak menetap atau bermukim. Pengiriman pesan haruslah mempertimbangkan data demografi, geografi dan psikografi khalayak tersebut. Ketiga data tersebut dapat memberikan gambaran mengenai budaya dan perbandingan generasi berdasarkan usia sebagai khalayak politik. Pengaruh budaya politik menjadi dasar bagaimana tingkat kesadaran sampai pada keterlibatan atau partisipasi seluruh rakyat di suatu negara terhadap peristiwa politik.

\section{Budaya Politik}

Budaya politik adalah pola hidup, sikap, prilaku dan prosedurprosedur yang telah terbentuk berdasarkan kebiasaan yang dilakukan terusmenerus dalam keterlibatannya dalam peristiwa politik yang menjadi pedoman bagi warga masyarakat bertindak atau berperilaku dalam upaya mencapai tujuan bersama. Menurut Dan Nimmo ${ }^{70}$ hakekatnya budaya politik terdiri atas pola kecendrungan kepercayaan, nilai, dan pengharapan yang diikuti secara luas dan pola ini dipelajari, cukup terdifusi dengan baik, dan relative stabil meskipun secara terus-menerus disusun kembali. Gabriel Almond dan Sidney Verba (1984) ${ }^{71}$ mengklasifikasikan tipe-tipe kebudayaan politik:

a. Budaya politik parokial (parochial political culture) yang ditandai dengan tingkat partisipasi politik masyarakat yang sangat rendah. Hal ini disebabkan faktor kognitif, misalnya tingkat pendidikan masyarakat yang rendah.

b. Budaya politik subyek (subject political culture) di mana anggotaanggota masyarakatnya memiliki minat, perhatian, mungkin pula

\footnotetext{
${ }^{70}$ Dan Nimmo, Komunikasi Politik: khalayak dan Efek, Bandung: PT. Remaja Rosdakarya, 2000, hlm. 37

${ }^{71}$ Gabriel Almond. \& Sidney Verba. Budaya Politik, Jakarta : Bina Aksara, 1984, hlm. 16
} 
kesadaran terhadap sistem secara keseluruhan, terutama terhadap output-nya, namun perhatian atas aspek input serta kesadarannya sebagai aktor politik, boleh dikatakan nol.

c. Budaya politik partisipan (participant political culture) yang ditandai oleh adanya perilaku bahwa seseorang menganggap dirinya ataupun orang lain sebagai anggota aktif dalam kehidupan politik sehingga menyadari setiap hak dan tanggungjawabnya (kewajibannya) dan dapat pula merealisasi dan mempergunakan hak serta menanggung kewajibannya.

Kebudayaan politik suatu bangsa dalam kenyataannya merupakan budaya politik campuran. Artinya tidak akan ditemukan dalam kenyataan empirik bahwa suatu bangsa hanya memiliki satu jenis kebudayaan politik saja. Dalam suatu masyarakat ditemukan inklanasi kepada salah satu tipe budaya politik, misalnya dalam budaya politik partisipan masih dapat dijumpai individu-individu yang tidak menaruh minat pada obyek-obyek politik secara luas. Menyadari realitas budaya politik yang hidup di masyarakat tersebut, Almond menyimpulkan adanya budaya politik campuran (mixed political culture) yang menurutnya lazim terjadi pada masyarakat yang senantiasa mengalami perkembangan dan dinamika yang pesat, sehingga sistem politik bisa berubah dan kultur serta struktur politik senantiasa tidak selaras. Budaya politik campuran yang dikemukakan Almond sebagai berikut:

a. Budaya Parokial-Subjek (The Parochial-Subject Culture). Tipe budaya politik saat sebagian besar penduduk menolak tuntutan-tuintutan ekslusif masyarakat suku yang feodalistik. Masyarakatnya mengembangkan kesetiaan terhadap sistem politik yang lebih kompleks dengan struktur-struktur pemerintahan pusat yang sentralistis.

b. Budaya Subyek-Partisipan (The Subject-Participant Culture). Proses peralihan dari budaya subyek menuju budaya partisipan yang sangat dipengaruhi oleh cara bagaimana peralihan budaya parokial menuju budaya subyek. Dalam budaya subyek-partisipan ini, sebagian besar penduduk telah memperoleh orientasi-orientasi input yang bersifat khusus dan serangkaian orientasi pribadi yang aktif; sementara sebagian penduduk masih terorientasi dengan struktur kekuasaan yang otoriter dan menempatkan partisipasi masyarakat pasif.

c. Budaya Parokial-Partisipan (The Parochial-Participan Culture). Kondisi ini biasanya terjadi di dalam negara yang sedang berkembang. Hampir seluruh negara berkembang memiliki budaya parokial. Oleh sebab itu, sistem politik mereka terancam oleh fragmentasi parokial yang tradisional, padahal mereka ingin secepatnya menjadi sebuah negara 
modern. Suatu masa, cenderung ke otoritarianisme dan pada waktu yang lain ke arah demokrasi.

d. Budaya Parokial-Subyek-Partisipan (Civic Culture). Civic culture (budaya kewarganegaraan) menekankan pada partisipasi rasional dalam kehidupan politik, digabungkan dengan adanya kecenderungan politik parokial dan subyek warganegara maka menjadikan sikapsikap tradisional dari penggabungannya dalam orientasi partisipan yang mengarah pada suatu budaya politik dengan keseimbangan aktivitas politik.

Keterlibatan dan adanya rasionalitas serta kepasifan, tradisionalitas, dan komitmen terhadap nilai-nilai parokial. kesimpulannya budaya politik ini merupakan penggabungan karakteristik dari ketiga budaya politik murni. Jadi budaya politik kewarganegaraan merupakan kombinasi antara karakteristik-karakteristik aktif, rasional, mempunyai informasi yang cukup mengenai politik, kesetiaan pada sistem politik, kepercayaan dan kepatuhan terhadap pemerintah, keterikatan pada keluarga, suku, dan agama.

\section{Opini Publik dan Tipologi Khayalak Komunikasi Politik}

Saat ini ada teknologi yang dikenal dengan drone yang pada awalnya merupakan pesawat tanpa awak untuk tujuan militer. Tapi sekarang digunakan untuk melihat objek gambar bisa rumah, lokasi tempat dan juga melihat kerumunan manusia sehingga terlihat kumpulan manusia dari sisi atas. Menurut Karl Mannheim ${ }^{72}$, mendefinisikan kerumunan sebagai kumpulan manusia yang secara fisik adalah kompak, terbentuk secara spontan, sebagian besar anggotanya bereaksi terhadap stimuli yang sama dan menurut cara yang sama. Kerumunan selalu merupakan pengorganisasian yang bersifat sementara dan tidak stabil, selalu insiden, ledakan perasaan karena merupakan integrasi berdasarkan sugesti yang cepat memainkan peranan penting. Lalu Mannheim ${ }^{73}$ juga menjelaskan pengertian publik adalah kesatuan orang banyak yang bukan berdasarkan interaksi perseorangan tetapi atas dasar reaksi terhadap stimuli yang sama. Reaksi itu muncul tanpa keharusan berdekatannya anggota publik itu secara fisik antara satu dengan yang lainnya. Jadi publik adalah sekelompok orang yang dihadapkan atau tertarik dengan suatu permasalahan atau isu-isu tertentu, seperti isu masalah ekonomi, pendidikan, politik, sosial, kesejahteraan, lingkungan, dan seterusnya.

Selanjutnya apa yang dimaksud dengan opini publik? Dan apa kaitannya dengan khalayak komunikasi politik? Maka dua pertanyaan

\footnotetext{
72 Karl Mannhem. Sosiologi Sistematis: suatu Pengantar Studi Tentang Masyarakat. Jakarta: Bina Aksara, 1987, hlm. 118

${ }^{73} \mathrm{Ibid}, \mathrm{hlm} .120$
} 
tersebut akan dijelaskan sebagai berikut, ada dua kata opini yang berarti pendapat dan publik seperti yang dijelaskan sebelumnya. Khalayak bisa dikatakan siapa saja yang menerima pesan atau informasi, dalam hal ini adalah pesan politik. Pesan politik biasanya pesan yang mempunyai tujuan dan terdapat tema dan persoalanan (issue) tertentu yang sudah direncakan untuk disampaikan kepada khalayak umum. Maka pada saat adanya kesamaan minat terhadap issue tertentu dan terkoneksi dan terintegrasi melalui berbagai media, akhirnya terbentuklah yang disebut opini publik. Opini publik juga bisa dikatakan sebagai penilaian sosial (social judgment). Menurut Clyde, L. King74, opini publik adalah penilaian sosial mengenai suatu persoalan yang penting dan berarti berdasarkan proses pertukaran pikiran yang sadar dan rasional.

Opini publik terbentuk diawali dari tahap demi tahap: pertama, konstruksi personal, yaitu opini pribadi bisa berbentuk verbal maupun non verbal (bisa salam bentuk peristiwa, kejadian, tingkah laku yang mengandung pesan secara implisit). Opini pribadi dalam bentuk issue yang akan memancing perhatian orang banyak. Kedua, tahap konstruksi sosial dimana opini pribadi disampaikan, dipublikasikan kepada publik bisa dari mulut ke mulut, dan biasanya sangat efektif melalui media massa dan media sosial di era digital ini. Ketiga, tahap konstruksi politik, yaitu saat issue terus berkembang dan menjadi issue hangat di kalangan masyarakat menjadi opini kelompok yang digeneralisasikan menjadi opini rakyat dan akhirnya dianggap menjadi suatu yang penting dan serius sampai mengusik kepentingan kekuasaan, kebijakan dan kewenangan. Tahap konstruksi politik menghubungkan opini rakyat (mulut ke mulut), opini di media massa, opini di dunia virtual (netizen) dengan kegiatan para pejabat publik (eksekutif, legislative dan yudikatif) terhadap issue yang menerpa sehingga terjadi pemusatan perhatian terhadap issue tersebut dan akhirnya terciptalah 'opini publik'.

Opini publik yang terbentuk dapat mempengaruhi partisipasi masyarakat luas. Lalu dapat diukur melalui survey dan polling oleh lembaga internal partai (untuk kebutuhan internal) dan juga lembaga yang indendent yang akan menyampaikan hasil temuannya kepada khalyak umum yang biasanya terkait dengan tingkat keterkenalan (popularitas), elatabilitas, integritas dan seterusnya. Jadi opini publik berawal dari opini pribadi yang mempunyai isi (content) tentang sesuatu (issue), lalu mempunyai arah untuk mendapatkan respon dari masyarakat umum (percaya-tidak percaya, mendukung-tidak mendukung) dan memiliki intensitas apakah kuat, sedang atau lemah yang akan terlihat dari sejauh mana issue itu terus berkembang seperti bola salju atau malah issue tersebut hilang seakan terbawa oleh angin lalu. Menurut Dan Nimmo ${ }^{75}$ ciri-ciri opini publik adalah:

\footnotetext{
${ }^{74}$ Dalam Soemarno AP, Komunikasi Politik, Jakarta: Universitas Terbuka, hlm. 9.7

${ }^{75}$ Nimmo, Op, Cit, hlm. 25
} 
a. Terdapat isi, arah dan intensitas mengenai opini publik yang berkembang. Hal ini menyangkut opini publik tentang tokoh politik (pejabat pemerintah, kandidat pejabat, pemimpin politik, pemimpin simbolik, partai, peristiwa, dan segala issue lainnya).

b. Kontroversi, artinya sesuatu yang tidak disepakati oleh seluruh rakyat.

c. Mempunyai volume berdasarkan kenyataan bahwa kontroversi itu menyeluruh, semua orang yang merasakan konsekwensi langsung dan tidak langsung daripadanya meskipun mereka bukan pihak pada pertikaian semula.

d. Relatif tetap, tidak bisa dipastikan berapa lama tapi opini publik yang menghasilkan kontroversi sering bertahan agak lama dalam memori masyarakat.

Seperti yang telah dibahas pada bab $\mathrm{I}^{76}$ mengenai tipologi khalayak komunikasi politik, dapat kita perhatikan bahwa bentuk piramida yang terdiri dari lapisan bawah adalah publik umum (general public) yaitu orang yang sekedar tahu atau sedikit tertarik masalah politik (interested) dan publik yang tidak peduli masalah politik (indifferent), lapisan kedua atau tengah adalah publik atentif (mempunyai perhatian pada politik) bisa termasuk para aktivis, dan posisi puncak adalah para elite opinion (The Leadership public), yang teridri dari politikus dan para profesional. Potensi terbentuknya opini publik adalah bersumber dari kalangan publik atentif, karena mereka yang mempunyai perhatian dan kepentingan terhadap aktivitas politik. Opini publik sangat kuat pengaruhnya bila lahir dari pemimpin opini (opinion leader) terlebih bila pemimpin opini adalah seorang yang kharismatik, tokoh yang disegani dan dita'ati sejumlah pengikutnya. Pemimpin opini bisa sebagai aktivis yang kedudukannya sebagai key person atau gate keeper yang menyaring seluruh isi komunikasi yang akan disampaikan kepada masyarakat dilingkungannya. Setelah publik atentif memunculkan opini publik terhadap issue tertentu, maka khalayak umum (general public) akan terkena stimulus dan digerakkan (walaupun awalnya pasif) sampai berkembang menjadi dukungan mayoritas masyarakat. Setelah meluasnya opini yang terbentuk dalam masyarakat maka terciptalah suatu kekuatan opini publik. Soemarno AP77 membandingkan penjelasan beberapa ahli mengenai kekuatan dari opini publik, yaitu:

a. V.O. Key, Jr (dalam Public Opinion and American Democrazy), menyatakan bahwa pendapat umum itu merupakan ungkapan sikap rakyat tentang pemerintah dan tentang politik (the expression of attitudes about government and politics).

\footnotetext{
${ }^{76}$ Lihat Bab I halaman: 5

${ }^{77}$ Soemarno AP, OP, Cit, hlm. 2.24
} 
b. A.V. Dicey mengatakan pendapat umum itu sebagai supernatural power dan pemerintah sendiri sangat berhati-hati serta menghargai pendapat umum ini.

c. Floyd Allport bahwa mengatakan bahwa pendapat umum mampu mendukung atau menghantarkan aktivitas pemerintah.

d. W. Lance Bennet mengatakan: "in the language of political system public opinion can be thought of as one of the inputs of the system that many effect the outputs, or binding decisions of government".

Dengan adanya opini publik yang terkait dengan peristiwa politik, maka publik akan terbagi berdasarkan budaya politik yang terbentuk dan tertanam dimasing-masing masyarakat sesuai kebiasaan di daerah dan lingkungannya. Klasifikasi khalayak komunikasi politik terkait budaya politik berdasarkan orientasi politiknya adalah sebagai berikut:

e. Budaya politik parokial, dengan tingkat partisipasi yang rendah disebabkan faktor kognitif akan tersebar di publik umum (general public), sehingga keterlibatannya hampir tidak ada. Secara umum mereka adalah yang terkait faktor pendidikan yang rendah, daerah yang belum maju secara sosial dan ekonomi atau masih di daerah pedalaman. Mereka bisa terlihat pada saat masa kampanye legislatf atau eksekutif, dimana tidak ada peran serta dalam kegiatan tersebut dan lebih dipertegas lagi saat hari pelaksanaan pemilu. Mereka bisa jadi karena belum faham tapi hanya mengikuti kebiasaan masyarakat disekitarnya. Mereka bisa jadi hanya ikut tapi asal-asalan atau sengaja melanggar tata cara pemilihan sehingga surat suara dinyatakan tidak sah dan mereka yang termasuk golongan putih (golput), yaitu mereka yang tidak mau datang apalagi memberikan suaranya. Dari tahunketahun jumlah mereka rata-rata $20-30 \%$ dari jumlah Daftar Pemilih Tetap (DPT).

f. Budaya Politik Subyek, masyarakat yang relatif sudah maju (sosial dan ekonomi) tapi masih bersifat pasif. Mereka memiliki minat, perhatian, kesadaran terhadap peristiwa politik namun sebatas di luar dari sistem politik secara praktis terutama terhadap output (kebijakan, kewenangan, kegiatan), mereka aktif dan berperan serta dalam kampanye, pemilu dan kegiatan-kegiatan yang diselenggarakan oleh pemerintah. Namun, mereka tidak mau terlibat sebagai sebagai aktor politik. Mereka bisa dikatakan masuk dalam kategori publik atentif, yaitu publik yang perhatian terhadap peristiwa politik, dari komunikator politik termasuk aktivis ada di dalamnya. Selama ingin berdiri dalam kondisi independen dan objektif para aktivis lebih memilih di luar pemerintah sebagai kontrol sosial kepada penguasa. 
g. Budaya politik partisipan, yaitu individu atau sekelompok orang dengan budaya politik yang ditandai dengan kesadaran politik sangat tinggi. Mereka terjun langsung dan terlibat menjadi aktor-aktor politik. Mereka adalah para elite opinion, bisa seorang politikus, atau profesonal dalam komunikasi politik. Mereka menjadi pekerjaan utama di dunia politik temasuk mendapatkan nafkah darinya, sehingga politik menjadi jalan hidup untuk mengabdi atau bisa jadi untuk mencari suatu kepuasan tertentu tergantung motif masingmasing individu, apakah aktualisasi diri, ambisi kekuasaan atau karena motif materi.

Kesimpulan dari hubungan budaya politik dan khalayak komunikasi politik adalah masalah partisipasi politik. Partisipasi berdasarkan definisi Closky: ${ }^{78}$

“... kegiatan-kegiatan sukarela (voluntary) dari warga masyarakat melalui mana mereka mengambil bagian dalam proses pemilihan penguasa secara langsung (direct) atau tidak langsung (indirect) dalam proses pembentukan kebijakan umum".

Berdasarkan pengertian tersebut bahwa partisipasi politik lebih kepada aktivitas masyarakat (warga negara) dalam turut memikirkan kehidupan negara. Intinya kegiatan partisipasi politik tertuju kepada dua subjek, yaitu 1) pemilihan penguasa, dan 2) melaksanakan segala kebijakan penguasa (pemerintah). Partisipasi yang murni harus datang dari dalam diri sendiri tanpa adanya tekanan dan paksaan dari luar dirinya. Partisipasi politik dapat dipahami melalui gambar dibawah ini:

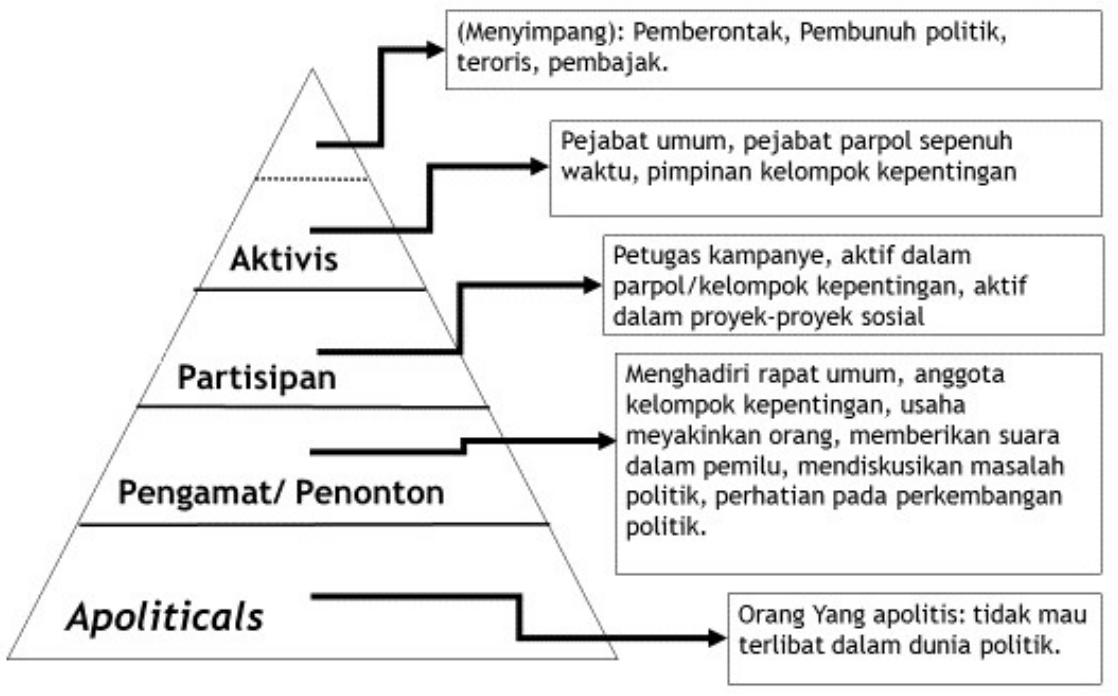

Gambar 4.3: Tingkatan atau piramida partisipasi politik (modifikasi)dari David F. Roth dan Frank L. Wilson (1980) dalam Soemarno AP (2009: 7.22)

${ }^{78}$ Soemarno AP, OP.Cit. hlm. 7.17 
Partisipasi merupakan kesadaran yang muncul dari pemahaman yang ada di dalam diri individu. Pemahaman tersebut sudah pasti tidak muncul dengan sendirinya tapi terbentuk dari berbagai faktor, yang pertama, peran pemerintah (sistem yang dipakai seperti otoriter atau demokrasi) sebagai penguasa dan puncak dari komunikator politik harus memberikan kebijakan untuk mengedukasi, mengadakan sosialisasi politik, memberikan ruang gerak, kesempatan kepada masyarakat untuk berpartisipasi, mengkritisi, dan termasuk memberikan hak untuk mencalonkan diri sebagai kandidat tentunya sesuai kapasitas dan kompetensinya. Kedua, peran partai politik yang mempunyai tugas bukan sekedar kampanye tapi melakukan edukasi politik kepada masyarakat. Ketiga, peran para politikus dan birokrat yang biasanya menggunakan jalur komunikasi langsung (direct communication) kepada masyarakat. Keempat, para aktifif, ahli / pengamat yang berfokus perhatiannya kepada masalah politik. kelima, keluarga dan lingkungan.

Tingkatan pada parisipasi politik, sangat tergantung dari akibat yang disebabkannya atau kembali kepada motif tujuannya, yaitu: 1) menduduki jabatan politik atau administratif, 2) mencari jabatan politik atau administratif, 3) keanggotaan aktif suatu organisasi politik, 4) keanggotaan pasif suatu organisasi politik, 5) keanggotan aktif suatu organisasi semu politik (quasi-political), 6) keanggotan pasif suatu organisasi semu politik (quasi-political), 7) partisipasi dalam rapat umum, demonstrasi dan sejenisnya, 8) partisipasi dalam diskusi politik informal minat dalam bidang politik, 9) memberikan suara dalam pemilu (voter).

\section{Efek dan Umpan Balik Komunikasi Politik}

Efek merupakan salah satu komponen dari proses komunikasi. Efek atau dampak (impact) diawali dari kognitif yaitu tahap pengetahuan (informasi) dari tahap tidak tahu menjadi mengetahui dan memahami, tahap kedua adalah afektif dimana tahap ini muncul 'rasa' dan mulai terlibat secara emosional dalam wujud senang, marah, sedih, simpati, empati dan sampai tahap ketiga, yaitu konatif (behavioral) di mana ada aksi, tindakan, kegiatan dan prilaku yang mucul terkait dengan pesan yang sampai kepada khalayak.

Wilbur Schramm mengatakan ${ }^{79}$, "alasan pokok untuk mempelajari proses komunikasi dan efek yang dihasilkan atau telah dicapai adalah kita ingin mengetahui tentang apa yang terjadi pada manusia bilamana menerima suatu pesan komunikasi tertentu dan untuk memperkirakan efek apa yang timbul dari komunikan tersebut". Dalam hal komunikasi politik efek yang

79 Dalam bukunya "Process and Effect of Mass Communication", dikutip dalam Rosady Ruslan. Kiat dan Strategi Kampanye Public Relations. Jakarta: PT. RajaGrafindo Persada. 2005, hlm. 20-21 
terjadi adalah perubahan dalam pendapat (opinion), yang terdiri dari opini pribadi (personal opinion), opini publik (public opinion), opini mayoritas (mayority opinion), sikap dan tingkah laku (attitudes and behavioral), pandangan, persepsi dan ide (conception, perception, ide), kepercayaan dan citra (trust dan image). .80

Selanjutnya efek akan lebih terukur dengan adanya umpan balik (feedback). Ralph Webb Jr ${ }^{81}$ membagi bentuk umpan balik, yaitu: pertama, Zero feedback, yaitu umpan balik yang nol (tidak ada), dimana pesan yang disampaikan oleh komunikator tidak dimengerti atau difahami oleh komunikan. Kedua, Neutral feedback, merupakan umpan balik yang netral atau setelah menerima pesan, komunikan bersifat tidak memihak. Ketiga, Positive feedback, yaitu umpan balik yang positif, pesan atau informasi yang disampaikan oleh komunikator tersebut ditanggapi dengan baik, disetujui, atau diterima secara baik. Keempat, Negative feedback, yaitu umpan balik negatif merupakan kebalikan dari positive feedback, pesan yang disampaikan oleh komunikator ditanggai secara negatif, skeptis, dan ditentang atau tidak disetujui oleh komunikan, contoh: interruption (gangguan dari pihak komunikan yang memotong pembicaraan yang sedang disampaikan oleh komunikator), disagreement (penolakan atau tidak disetujui dan tidak mendukung pesan dari komikator), criticism (kritikan dan kecaman dari komunikan kepada komunikator akibat tidak sependapat atau sepaham, bisa lebih jauh menjadi kemarahan yang meluap bahkan sampai benturan fisik).

\section{Khalayak Politik Berdasarkan Generasi}

Mengadopsi teori generasi yang dicetuskan oleh William Strauss dan Neil Howe dalam kajiannya mengenai identifikasi siklus generasi di Amerika Serikat. Strauss dan Howe ${ }^{82}$ menuliskan teori mengenai generasi ini dalam buku yang berjudul Generations: The History of America's Future, 1584 to 2069 (1991), yang menceritakan mengenai sejarah suksesi generasi anglo-American serta mengidentifikasi munculnya siklus generasi di sejarah Amerika Serikat. Staruss dan Howe mempublikasikan buku keduanya pada tahun 1993 yang berjudul 13th Gen: Abort, Retry, Ignore, Fail? yang menjelaskan generasi kelahiran 1961-1981 sebagai Gen-Xers disebut generasi ke-13 terhitung sejak Amerika Serikat resmi menjadi sebuah negara. Lalu pada 2000 Strauss dan Howe juga mengeluarkan sebuah buku dengan judul Millenials Rising: The Next Generation yang meneliti mengenai kepribadian mengenai Gen Y.

\footnotetext{
80 Ibid.

81 lbid.

82 Wikipedia, https://en.wikipedia.org/wiki/Strauss\%E2\%80\%93Howe_generational_theory , 5 Agustus 2016 (Bersumber dari buku: William Strauss \& Neil Howe. Generations: the history of America's future, 1584 to 2069. New York: Morrow, (C1991).
} 
Sejak munculnya Teori Generasi (Generation Theory), kita diperkenalkan istilah traditionalist, baby boomers, generasi $X, Y, Z$ dan alpha. Segala sesuatu terutama yang berhubungan dengan prilaku, gaya hidup, profesi, budaya yang sering dikaitkan dengan ciri-ciri dari generasi-generasi tersebut. Teori yang dikemukakan oleh Strauss dan Howe merupakan asumsi yang sangat subjektif. Dalam tulisan ini penulis akan mengadopsi teori Generasi dalam memahami khalayak politik di Indonesia. Dengan perspektif yang disesuaikan dengan sejarah dan budaya Indonesia, penulis membuat rentan waktu setiap generasi disesuaikan dengan kejadian-kejadian yang sangat berpengaruh kepada suatu generasi sesuai eranya. Harapannya akan menjadi jalan tengah agar antar generasi dapat saling memahami dan mengerti peran masing-masing generasi dalam dinamika politik yang terjadi. Sehingga peralihan kekuasaan antar generasi terjadi secara indah, ikhlas dan penuh kasih sayang. Generasi yang tua menyayangi yang muda, generasi muda menghormati yang tua. Tanpa ada kesan kudeta, permusuhan dan karena ambisi kekuasaan semata. Berdasarkan Teori Generasi ada enam (6) generasi yang lahir setelah perang dunia kedua dan berhubungan dengan masa kini, yaitu:

a. Traditionalist (1928-1945), generasi yang lahir pada saat Perang Dunia I, dimana Indonesia masih dalam kondisi dijajah oleh Belanda dan Jepang, era dimana munculkan gerakan pemuda (Sumpah Pemuda) dan gerakan perserikatan organisasi secara nasional (Syarikat Islam, Budi Utomo, Muhammadiyah, Nahdatul Ulama dan sebagainya). Disebut juga era Proklamasi menandakan lahirnya Negara Kesatuan Indonesia, semangat perjuangan dan kemerdekaan.

b. Baby Boomer (1946-1964), generasi yang lahir setelah Perang Dunia II yang dampaknya masih terasa dalam beberapa tahun di setiap negara terutama yang terlibat langsung. Era ini merupakan masa awal pertumbuhan politik, ditandai masih adanya gejolak pertentangan ideologi yang ingin dipakai di Negara yang baru saja lahir, seperti adanya pemberontakan Darul Islam (DI/TII) tahun 1949, Pemerintahan Revolusioner Republik Indonesia (PRII)/ Permesta tahun 1958, Partai Komunis Indonesia (PKI) tahun 1965. Pernah berbentuk Negara Federal terdiri dari beberapa Negara bagian, yaitu Republik Indonesia Serikat (RIS). Beberapa kali berubah kabinet pada saat masa pemerintahan parlementer. Generasi yang adaptif, mudah menerima dan menyesuaikan diri. Dianggap sebagai generasi yang mempunyai pengalaman hidup dalam dinamika perubahan politik yang cepat.

c. Generasi X (1965-1976), generasi yang lahir di era ini terjadi peralihan kekuasaan dari Orde Lama ke Orde Baru. Di tandai dengan munculnya gerakan G 30 S PKI, lalu terjadi serah terima kekuasaan yang ditandai dengan penyerahan Surat Perintah Sebelas Maret 
(Supersemar) dari presiden Sukarno ke Letjen. Suharto. Pemerintahan Orde Baru menekankan stabilitas nasional demi lancarnya pembangunan. Pemerintahan yang konstan dengan gaya otoriter militer. Hal ini ditandai dengan adanya Garis-Garis Besar Haluan Negara (GBHN) dan Rencana Pembangunan Lima Belas Tahun (REPELITA) sebagai rujukan kerja Pemerintah. Kebebasan pers dan kebebasan berpendapat sangat terkekang, adanya Pemilu dengan hanya diperbolehkan di ikuti oleh dua partai politik dan satu golongan karya. Terlaksananya Pemilu pada masa ini hanya mengesankan seolah-olah menerapkan sistem demokrasi yang faktanya selama Orde Baru berkuasa hanya Golongan Karya yang boleh menang Pemilu, sehingga seluruh jabatan strategis politik hanya didominasi kekuatan penguasa pemenang Pemilu. Seluruh pegawai negri sipil (PNS) wajib berbaju kuning dan berlambang pohon beringin.

d. Generasi Y (1977-1998), Era ini adalah kelanjutan kekuasaan Orde Baru, namun akumulasi dari tekanan sistem otoriter akhirnya membuat suatu perlawanan mulai dari protes-protes perorangan. sampai dengan gerakan masal yang dipelopori mahasiswa dampak dari peritiwa penembakan mahasiswa trisakti tahun 1998. Mahasiswa dan beberapa unsur masyarakat bersama-sama berdeomostrasi menuntut mundurnya presiden Suharto sebagai simbol atau representasi kekuatan Orde lama. Generasi yang lahir di era ini dikenal dengan sebutan generasi millenial atau milenium. Ungkapan generasi $Y$ mulai dipakai pada editorial koran besar Amerika Serikat pada Agustus 1993. Generasi ini banyak menggunakan teknologi komunikasi instan seperti email, SMS, instan messaging dan lahirnya media sosial di mulai dengan munculnya Bulletin Board System (BBS) pada tahun 1978.

e. Generasi Z (1999-2012), ini disebut era Reformasi, setelah penggulingan kekuasaan Orde Baru. Era ini ditandai dengan kebebasan berpendapat dan pers. Partai baru bermunculan dan berjumlah sampai puluhan. Media massa mulai dari cetak, radio, dan terutama stasiun televisi bermunculan. Setiap orang diberikan ruang untuk mengkritisi pemerintah. Banyak undang-undang atau peraturan pemerintah yang bersifat otoriter di rubah menjadi lebih demokratis. Generasi yang lahir pada era ini disebut juga $i$ Generation, generasi net atau generasi internet. Mereka memiliki kesamaan dengan generasi $Y$, tapi mereka mampu mengaplikasikan semua kegiatan dalam satu waktu seperti nge-tweet menggunakan smartphone, browsing dengan Personal Computer (PC), dan mendengarkan musik menggunakan headset sambil sibuk sendiri dengan gadget-nya sendiri, fenomena ini 
disebut dengan istilah 'Phubbing'83 Apapun yang dilakukan kebanyakan berhubungan dengan dunia maya. Sejak kecil mereka sudah mengenal teknologi dan akrab dengan gadget canggih yang secara tidak langsung berpengaruh terhadap kepribadian mereka.

f. Generasi Alpha (2013-2025), di era ini ada fenomena baru yang muncul dengan munculnya tokoh-tokoh yang berbeda dan baru. Seperti suatu produk, konsumen pasti akan sangat penasaran dengan sesuatu yang baru, unik dan berbeda dari yang ada, contoh kata kunci 'blusukan' jadi trend dan menular ke politikus lainnya. Maka Kekuatan media semakin nyata dalam pembentukan citra (image) tokoh politik dan menggiring opini publik. Opini publik bisa sangat ditakuti oleh penguasa. Setelah sekian lama dalam kekuasaan otoriter dan banyak pemimpin, birokrat yang terkena kasus hukum menjadikan dinamika politik lebih cair. Transparansi, kredibilitas, integritas dan kopetensi menjadi tuntutan masyarakat dalam memilih pemimpinnya baik legislatif dan eksekutif. Generasi yang lahir sesudah generasi Z, lahir dari generasi $X$ akhir dan Y. Generasi yang sangat terdidik karena masuk sekolah lebih awal dan banyak belajar, rata-rata miliki orang tua yang dengan tingkat perekonomian yang sudah mapan, terdidik dan menguasai berbagai teknologi elektronik dan komunikasi.

Partisipasi rakyat di suatu negara terhadap peristiwa politik ditandai dari keterlibatannya dalam pesta rakyat (election) dan melaksanakan kebijakan pemerintah. Karakteristik khalayak politik berdasarkan generasi sangat berpengaruh dalam menentukan berhasil atau tidaknya para kandidat dalam Pemilihan umum. Pengaturan strategi kampanye harus benar-benar diperhitungkan terkait komposisi pemilih berdasarkan sebaran tipe generasi yang mempunyai suara dalam pemilihan. Maka tulisan ini akan membahas karakteristik komunkator politik dan khalayak komunikasi politik beradasarkan tipe generasinya. Kajian komunikasi antar generasi juga menjadi studi yang menarik. Komunikasi politik generasi ke generasi (antar generasi): contoh peristiwa penculikan Sukarno oleh para pemuda sebelum hari Proklamasi di Regas Dengklok, gerakan angkatan 66 (baby boomers) melawan Orba (elit dominan tradisionalist), peristiwa Malari tahun 1974 (generasi $\mathrm{x}$ ) melawan Orba (baby boomers), gerakan angkatan 98 (generasi $\mathrm{x}$ )

\footnotetext{
83 Phub (verb)-slang, Phub adalah bentukan kata dari ph(one)+Snub: to ignore (a person or one's surroundings) when in social situation by busying oneself with a phone or other mobile device: Hey, are you phubbing me? I hate to see a mother wheeling a stroller while phubbing her baby. Pelakunya disebut 'Phubber' (www.dictionary.com).
} 


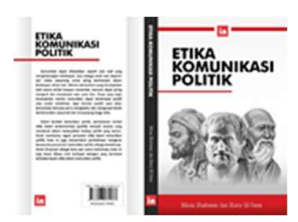

yang melakukan perlawanan terhadap rezim Orba (baby boomers). Bisa jadi suatu generasi berpotensi akan menjadi oposisi dengan generasi lainnya. Lalu kita juga bisa melihat bagaimana pola komunikasi antar generasi di Partai Politik, di Parlemen (DPR) atau di kabinet pemerintah. Secara umum senior akan meremehkan juniornya dan junior akan sungkan kepada seniornya. Gap antara generasi muda dan tua di sebuah partai berpotensi terjadinya perpecahan seperti kasus Partai Golkar dan Partai Persatuan Pembangunan (PPP) tahun 2014.

Generasi tradisionalist, untuk saat ini (2016) mereka adalah yang paling senior. Dengan pengalaman hidup yang sudah panjang dan paripurna, begitupun dengan tokoh dan politikus yang sudah mempunyai jam terbang yang banyak di dunia politik. Mereka menjadi panutan namun dan disegani baik di kalangan elit maupun di masyarakat umum. Tokoh yang tergolong generasi ini contohnya seperti, BJ. Habibie (1936), termasuk Jusuf Kalla (1942) dan lainnya rekan seangkatan mereka. Generasi baby boomers adalah generasi yang hari ini (sejak era reformasi s/d 2016) merupakan generasi yang mewarnai elit dan politik di Indonesia, mereka merasakan dua rezim kepemimpinan (ORLA dan ORBA) ${ }^{84}$. Saat ini yang termasuk generasi ini diantaranya seperti Megawati (1947), Prabowo (1951), Wiranto, SBY (1949), termasuk Jokowi (1951). Sedangkan para pemilih atau masyarakat berdasarkan data BPS di dominasi oleh generasi $X$ dan $Y$ sebagai data dominan di daftar pemilih tetap. Maka perbedaan generasi ini dalam hal politik perlu kiat dan strategi khusus dari elit atau politikus kepada generasi $X$ dan $Y$ sesuai dengan karakter dan latar belakangnya. Tokoh atau politikus di tahun 2016 merupakan era terakhir mereka meraih atau mempertahankan karier, kedudukan dan kekuasaan.

Generasi X pada saat ini (2016) berumur antara 40-51 tahun. mereka adalah generasi transisi peralihan, perlahan-lahan mulai masuk pada jajaran elit puncak di Indonesia, sebut saja mereka adalah Anas Urbaningrum (1969), Basuki Tjahaya Purnama (1966), Anas Baswedan (1969), Muhammad Nazarudin (1978), Angelena Sondak (1977), dan seterusnya. Umur 40 tahun ${ }^{85}$

84 Orde lama era presiden Sukarno (1901), Orde Baru Suharto (1921), keduanya era sebelum tradisionalist.

${ }^{85}$ QS: Al-Ahqaaf, 46/15: “Kami perintahkan kepada manusia supaya berbuat baik kepada dua orang ibu bapaknya, ibunya mengandungnya dengan susah payah, dan melahirkannya dengan susah payah (pula). Mengandungnya sampai menyapihnya adalah tiga puluh bulan, sehingga apabila dia telah dewasa dan umurnya sampai empat puluh tahun ia berdoa: "Ya Tuhanku, tunjukilah aku untuk mensyukuri nikmat Engkau yang telah Engkau berikan kepadaku dan kepada ibu bapakku dan supaya 
merupakan umur dimana secara biologis masa puncak pematangan fisik terutama bagian depan otak manusia yang disebut prefontal Cortex ${ }^{86}$, yaitu bagian otak yang letaknya tepat dibelakang dahi (jidat) dan mempengaruhi tingkah laku manusia. Secara pengalaman intelektual, emosional, dan spiritual pada umumnya mulai matang dan telah memetik buah pelajaran dan hikmah selama hidupnya. Mereka akan berpikir lebih serius mengenai kehidupan, berkeluarga, kemapanan dalam hal perekonomian dan juga muncul kepedulian atau ambisi dengan masalah politik. Bisa kita amati bahwa ada kecendrungan setelah sukses menjadi pengusaha, mencapai puncak karier dan profesi apa saja, akhirnya terjun ke dunia politik, mulai dari mendirikan Partai baru, ikut mencalonkan diri sebagai kandidat politik (eksekutif atau legislatif), dan seterusnya. Kalaupun ada yang setelah umur 40 tahun tetap tidak berubah bahkan semakin menyimpang dari azas kenormalan, kelayakan, berarti bisa karena beberapa faktor termasuk asupan pendidikan, lingkungan, dan peristiwa yang dirasakan penting oleh manusia. Bila tidak ada transformasi dari negatif ke positif dikhawatirkan tabia't buruk manusia itu akan selalu melekat walaupun sudah melewati umur 40 tahun. Menurut penulis kurang lebih mulai umur 40 tahun seharusnya

Generasi Y atau disebut generasi milenial (kelahiran 1977-1998) berumur $18 \mathrm{~s} / \mathrm{d} 38$ tahun, mereka mempunyai pola tingkah laku berbeda dengan generasi sebelumnya. Mereka adalah generasi yang bertumbuh dengan keleluasaan informasi. Mereka sadar gaya hidup sekaligus lebih peduli sesama. Dalam Digital Culture and Religion in Asia, Sam Han dan Kamaludeen Mohamed Nasir menyebutkan bahwa generasi milenia ini lebih liberal dibandingkan generasi sebelumnya. Mereka peduli dengan sesama.

aku dapat berbuat amal yang shaleh yang Engkau ridai; berilah kebaikan kepadaku dengan (memberi kebaikan) kepada anak cucuku. Sesungguhnya aku bertobat kepada Engkau dan sesungguhnya aku termasuk orang-orang yang berserah diri". (umur 40 tahun adalah titik balik / pulang, pertumbuhan sel hanya bertahan dan bertambah kematian sel: menua, manusia sudah mencicil kematiannya).

${ }^{86}$ Ahli Saraf Joseph deLoux menemukan bahwa daerah prefrontal berperan dalam menata dan meredam emosi dan manusia, rusaknya bagian kiri membuat mudah cemas dan rasa takut yang hebat, rusak bagian kanan akan menjadi kelewat 'ceria'. Kerusakan di bagian ini misalnya cidera, tumor akan menimbulkan gangguan pada tingkah lakunya. Adrian Raine (guru besar psikolog Universitas Suthern California) penelitian 38 otak pria dan wanita, dengan alat PET (Positron Emission Tomography) kerusakan pada daerah ini karena cidera, trauma lahir, atau luka-luka di kepala, akan membuat anak dari keluarga baik-baik melakukan perbuatan criminal yan tercela (dalam Paisak, OP, Cit, hlm. 233-234, dan penelitian terkini oleh Prof. Sarah Jayne Blakemore ahli syaraf (University College London), berdasarkan penelitiannya memaparkan bahwa prefrontal cortex mengalami perkembangan paling lama mulai dari anak-anak sampai umur antara 30 s/d 40 tahun, sumber: http://www.icn.ucl.ac.uk 
Inilah generasi yang bisa berpindah pekerjaan karena merasa tak sesuai dengan jiwanya dalam preferensi politik mereka lebih rasional, mempertimbangkan dengan rasio, logika, dan mempunyai keleluasaan mengakses informasi secara mandiri, misalnya melalui dunia maya untuk menentukan pilihan politiknya. Sebagai contoh apa yang terjadi dengan keberhasilan Barack Obama pada dua kali pemilihan di AS. Presiden kulit hitam pertama itu mengantongi 66 persen dan John McCain hanya 23 persen pada jajak pendapat 2008. Itu adalah hitung-hitungan untuk usia di bawah 30 tahun. Perolehan untuk pemilih di atas 30 tahun adalah 51-49 persen. Selama empat dekade, belum pernah terjadi perbedaan angka antara pemilih muda dan pemilih senior yang begitu jauh (kompas, 21 Maret 2016). Hal ini bisa jadi karena cara kampanye dan pendekatan Barack Obama dengan menggunakan jaringan sosial media seperti facebook, twitter, yang memang digandrungi oleh generasi Y (milenial). Meskipun komunikasi tatap muka masih merupakan strategi yang ampuh, namun kecepatan penyebaran informasi tidak ada yang lebih cepat dari kecepatan jaringan internet yang menggunakan teknologi satelit, sehingga komunikasi antar benua pun bisa hitungan detik dengan umpan balik yang relatif cepat.

Pesta demokrasi rakyat di Indonesia terjadi tiap lima tahun sekali. dan bila diprediksi dua Pemilu kedepan yaitu tahun 2019 dan 2024 dengan perkembangan usia setiap generasi seperti dibawah ini:

Tabel 4.4: Prediksi Perkembangan data demografi Pemilu

\begin{tabular}{|l|c|c|c|c|}
\hline \multirow{2}{*}{ Generasi } & \multirow{2}{*}{ Kelahiran } & \multicolumn{3}{|c|}{ Umur } \\
\cline { 3 - 5 } & & 2014 & 2019 & 2024 \\
\hline Traditionalist & $1928-1945$ & $69-86$ & $74-91$ & $79-96$ \\
\hline Baby Boomers & $1946-1964$ & $50-68$ & $55-73$ & $60-78$ \\
\hline Generasi X & $1965-1976$ & $38-49$ & $43-54$ & $48-59$ \\
\hline Generasi Y & $1977-1998$ & $16-37$ & $21-42$ & $26-47$ \\
\hline Generasi Z & $1999-2012$ & $2-15$ & $7-20$ & $12-25$ \\
\hline Generasi Alpha & $2013-2025$ & 1 & 6 & 11 \\
\hline
\end{tabular}

Berdasarkan data diatas, secara aktor politik generasi tradisonalist pada pemilu 2019 adalah purna waktu, dan keterlibatannya sudah semakin kecil. Baby boomers pada pemillu 2019 dan 2024 berumur antara 55 s/d 78, dikalangan birokrat dan pegawai negeri ini adalah usia pensiun, namun tidak bagi jabatan politik bisa bebas asalkan masih dalam kondisi sehat jasmani dan 
rohani. Generasi X pada pemilu 2019 dan 2024 berumur antara 43 s/d 59 merupakan peralihan kepemimpinan politik, mereka akan mendominasi di elit dan birokrat. Generasi Y pada pemilu 2019 dan 2024 berumur antara 21 s/d 47 memasuki usia menjelang dewasa dan merupakan masa transisi keminatan, kepedulian di dunia politik, mungkin sebagian kecil sudah terjun ke dunia politik. Lalu generasi $Z$ generasi remaja menuju dewasa di mana masih usia sekolah dalam proses belajar dan mencari tahu jati diri, mereka sebagai "pemilih pemula" dalam Pemilu 2019 dan 2024. Generasi Alpha adalah generasi anak-anak yang belum memahami masalah politik.

Selanjutnya gambaran generasi pada khalayak komunikasi kompol. Maka gambarannya berdasarkan bonus demografi diprediksi akan terjadi antara tahun 2020 s/d 2030, maka diambil tahun 2025 sebagai representasi dari era bonus demografi adalah sebagai berikut:

Tabel 4.5: Struktur usia penduduk Indonesia tahun $2025^{87}$

\begin{tabular}{|l|c|c|c|}
\hline \multicolumn{1}{|c|}{ Generasi } & Usia & $\begin{array}{c}\text { Jumlah } \\
\mathbf{( 0 0 0 )}\end{array}$ & Persentase \\
\hline Traditionalist & $80-97$ & 6,133 & $2.15 \%$ \\
\hline Baby Boomers & $61-79$ & 27,562 & $9.65 \%$ \\
\hline Generasi X & $49-60$ & 32,703 & $11.45 \%$ \\
\hline Generasi Y & $27-48$ & 81,057 & $28.39 \%$ \\
\hline Generasi Z & $13-26$ & 68,068 & $23.84 \%$ \\
\hline Generasi Alpha & $0-12$ & 69,996 & $24.52 \%$ \\
\hline
\end{tabular}

Menurut data prediksi bonus demografi 2025 dikaitkan teori generasi bisa dilihat dari komposisi yang mempunyai hak memberikan suara di dominasi oleh generasi $Y$, dan sebagian generasi $Z$ (karena masih termasuk umur di bawah 17 tahun), lalu generasi $X$ dan terakhir baby boomers. Bonus demografi adalah fenomena meningkatnya jumlah usia produktif sehingga penduduk Indonesia akan didominasi oleh usia produktif. Presiden Jokowi menjelaskan tentang bonus demograf sebagai berikut: "Di mana penduduk dengan umur produktif jumlahnya sangat besar, sementara usia muda dan lanjut tidak banyak," Pemerintah Indonesia memprediksi, jumlah penduduk

87 Data diolah berdasarkan data Badan Pusat Statistik (BPS) diperkirakan struktur usia penduduk Indonesia pada saat bonus demografi di Indonesia tahun 2025 (BPS, 2013). 
usia produktif atau dapat disebut usia angkatan kerja mendominasi hingga 70 persen. Sedangkan 30 persen merupakan penduduk usia muda dan lanjut usia. "Jumlah usia angkatan kerja mencapai 70 persen. Sedangkan sisanya 30 persen adalah penduduk di bawah usia 15 tahun dan di atas 65 tahun." 88 Bila kita lihat usia kerja yang dimaksud adalah mulai dari generasi X, Y dan Z. begitu pula dengan merujuk data dari BPS, demikan pula terkait partisipasi dalam dunia politik, mulai sebagai pemberi suara, simpatisan, sampai terlibat langsung sebagai aktor politik. Namun, generasi $X$ dan $Y$ yang murni terkait dunia politik karena berdasarkan data generasi $Z$ masih ada yang dibawah 17 tahun.

Selanjutnya berdasarkan tahun kelahiran maka dapat digambarkan kondisi generasi berkaitan dengan pengaruh kondisi dan sistem politik di Indonesia dalam tabel dibawah ini:

Tabel 4.6: Generasi Politik di Indonesia Mengadobsi Teori Generasi

\begin{tabular}{|c|c|c|c|}
\hline Kelahiran & Generasi & Situasi Politik & $\begin{array}{c}\text { Pengaruh Teknologi } \\
\text { (Iconic Technology) }\end{array}$ \\
\hline 1928-1945 & Traditionalist & $\begin{array}{l}\text { Pra kemerdekaan, semangat } \\
\text { perjuangan, kemerdekaan, } \\
\text { kebangsaan, persatuan tumbuh, } \\
\text { peralawan terhadap penindasan } \\
\text { penjajahan. Persaingan dasar } \\
\text { ideologi negara tumbuh dan } \\
\text { berkembang. }\end{array}$ & $\begin{array}{l}\text { Media cetak (koran, } \\
\text { majalah: visual), radio } \\
\text { (Wairless): Audio, motor } \\
\text { vehicle, Aircraft, surat tulis } \\
\text { tangan,), Gramophone } \\
\text { (piringan hitam: alat yang } \\
\text { mempunyai pena yang } \\
\text { bergetar untuk } \\
\text { menghasilkan bunyi dari } \\
\text { sebuah disc. }\end{array}$ \\
\hline 1946-1964 & $\begin{array}{l}\text { Baby } \\
\text { Boomers }\end{array}$ & $\begin{array}{l}\text { Era kemerdekaan, berakhirnya } \\
\text { perang dunia ke } 2 \text { dengan } \\
\text { dibomnya kota Hirosima dan } \\
\text { Nagasaki (Jepang) oleh Amerika, } \\
\text { mencari-cari format yang pas } \\
\text { sistem pemerintahan, pola yang } \\
\text { berubah-ubah, parlementer- } \\
\text { presidential, disebut sebagai } \\
\text { Orde lama (Demokrasi } \\
\text { Terpimpin). Tiga ideologi besar: }\end{array}$ & $\begin{array}{l}\text { TV (1956): Audio Visual, } \\
\text { Transistor Radio (1955). } \\
\text { Audio Cassette (1962). Kantor } \\
\text { pos sarana penting } \\
\text { mengirim surat (pesan } \\
\text { tertulis), Telephon (fixed } \\
\text { line). }\end{array}$ \\
\hline
\end{tabular}

${ }^{88}$ kependudukan.jogjaprov.go.id ( 1/8/2015)

http://www.kependudukan.jogjaprov.go.id/olah.php?module=berita\&id=JokowilndonesiaAkanMeng hadapiBonusDemografidi20202030, diakses 8 Agustus 2016. 


\begin{tabular}{|c|c|c|c|}
\hline & & $\begin{array}{l}\text { Nasionalis, Agama, Komunis. } \\
\text { Tidak ada kebebasan pers. Ketua } \\
\text { MPR, MA sebagai mentri. }\end{array}$ & \\
\hline 1965-1976 & Generasi X & $\begin{array}{l}\text { Era orde baru, tampil sebagai } \\
\text { penyelamat dari Kudeta gagal G } \\
30 \text { S PKI (misterius), } \\
\text { menamakan diri era } \\
\text { Pembangunan. Masa-masa } \\
\text { bulan madu Orde Baru } \\
\text { (Demokrasi Pancasila). } \\
\text { Membatasi kegiatan politik, } \\
\text { semua Partai politik harus } \\
\text { berideologi Pancasila. }\end{array}$ & $\begin{array}{l}\text { VCR (1976), Walkman } \\
\text { (1979), IBM PC (1981). } \\
\text { Telephon koin, Warung } \\
\text { telekomunikasi (Wartel). }\end{array}$ \\
\hline $1977-1998$ & Generasi Y & $\begin{array}{l}\text { Kelanjutan babak era Orde Baru } \\
\text { kepemimpinan otoriter dengan } \\
\text { pendekatan militer, kendali } \\
\text { penuh pemerintah dengan } \\
\text { tujuan stabilitas nasional, tidak } \\
\text { adanya kebebasan pers, pola tiga } \\
\text { partai yang di dominasi partai } \\
\text { tunggal Golkar sebagai } \\
\text { penyokong pemerintah, krisis } \\
\text { moneter. }\end{array}$ & $\begin{array}{l}\text { Radio panggil satu arah } \\
\text { (pager), Handphone (Hp)/ } \\
\text { telephon selular/ Mobile, } \\
\text { Laptop/ Netbook (komputer } \\
\text { jinjing), Internet, email, SMS, } \\
\text { CD, VCD, DVD (1995), } \\
\text { Playstation, Xbox, MP3 } \\
\text { player, IPod. Warung } \\
\text { internet (Warnet). }\end{array}$ \\
\hline 1999-2010 & Generasi Z & $\begin{array}{l}\text { Era Reformasi, terbukanya keran } \\
\text { demokrasi, kebebasan } \\
\text { berpendapat, bermunculan } \\
\text { banyak partai. Partai PDIP } \\
\text { pemenang Pemilu yang selama } \\
\text { ini selalu di posisi terbawah. }\end{array}$ & $\begin{array}{l}\text { Multi media dan teknologi } \\
\text { touch screen, Macbook, IPad, } \\
\text { Google, Social media, } \\
\text { Facebook, Twitter, youtube, } \\
\text { Playstation (PS3), Blackberry } \\
\text { Messenger (BBM), Android, } \\
\text { Smart phone, game online. }\end{array}$ \\
\hline 2011-2025 & Generasi Alfa & $\begin{array}{l}\text { Berkembangnya konsultan } \\
\text { politik, marketing politik dan } \\
\text { Public Relations politik, era } \\
\text { dominasi peran media. Personal } \\
\text { \& political branding, Kekuasaan } \\
\text { Media, dan era digital, internet, } \\
\text { media sosial sebagai saluran } \\
\text { komunikasi politik. Kekuatan } \\
\text { opini publik, opini netizen. }\end{array}$ & $\begin{array}{l}\text { Trend social melalui smart } \\
\text { phone, tablet: Whatsup, } \\
\text { instragram, Path, Line, google } \\
\text { glass, graphene, nano- } \\
\text { computing, 3-D printing, } \\
\text { driverless cars, Dan teknologi } \\
\text { inovasi lainnya yang terus } \\
\text { berkembang. }\end{array}$ \\
\hline
\end{tabular}

Poin-poin penting berdasarkan penjelasan tabel 4.6 adalah: 1) kurang lebih umur $40 \mathrm{~s} / \mathrm{d} 60$ mendominasi elite opinion, 2) aktifis di dominasi oleh pemuda, mahasiswa $17 \mathrm{~s} / \mathrm{d} 30$ contoh setiap era semua gerakan mahasiswa 
terjadi tapi setelah menjadi pejabat terjadi perubahan dari paradigmanya (transformasi aktifis ke pejabat / birokrat), idealism mulai luntur dan lebih kepada pragmatism. 3) komposisi generasi di DPR, cabinet, hari ini (2016) masih di dominasi generasi baby boomers, dan generasi X. 3) khalayak komunikasi politik berdasarkan generasi sangat terpengaruh dengan situasi politik di zamannya tumbuh dan berkembang dan teknologi komunkasi yang digunakan. Kajian generasi ini diharapkan dapat berkembang dan digali fenomena-fenomena, konflik antar generasi dalam perspektif komunikasi politik. Sebagai contohnya penelitan longitudinal komunikasi politik SBY dalam kajian pola komunikasi pada Pilpres 2004 dan pilpres 2009 dimana beliau selalu menang, bagaimana pola dan strategi komuniasi kepada generasi $X$ dan $Y$, dan sebagainya.

\section{Daftar Pustaka}

Achmad, Mudlor. (tanpa tahun). Etika Dalam Islam. Surabaya: Al-ikhlas.

Adji, Oemar Seno. 1973. Mass Media dan Hukum. Jakarta: Erlangga.

Ahmad, Zainal Abidin. 1974. Negara Adil Makmur Menurut Ibnu Sina. Jakarta: Bulan Bintang.

Alfian. 1991. Komunikasi Politik dan Sistem Politik Indonesia. Jakarta: Gramedia Pustaka Utama.

Al-Ghazali, Imam. 1995. Ringkasan Ihya Ulumuddin. Jakarta: Pustaka Amani.

Almond, Gabriel dan James S. Coleman [Eds.]. 1960. The Politics of the Developing Areas. Princeton University Press.

Almond, Gabriel dan Sidney Verba. 1990. Budaya Politik: Tingkah Laku Politik dan Demokrasi di Lima Negara. Jakarta: Bumi Aksara.

Alonso, Sonia. 2011. The Future of Representative Democracy. Cambridge University Press.

Arifin, Anwar. 1992. Komunikasi Politik dan Pers Pancasila. Jakarta: Media Sejahtera. . 2011. Komunikasi Politik: Filsafat, Paradigma, Teori, Tujuan, Strategi dan Komunikasi Politik Indonesia. Yogyakarta: Graha Ilmu.

Bahm, Archie J. 2003. Filsafat Perbandingan: Filsafat Barat, India, Cina dalam Perbandingan. Yogyakarta: Kanisius. 
Bambang S. dan Sugianto. 2007. Pendidikan Kewarganegaraan. Surakarta: Penerbit Grahadi.

Barker, Ernest. 1962. The Politics of Aristotle. Oxford University Press.

Bastian, Indra. 2007. Akuntansi untuk LSM dan Partai Politik. Jakarta: Erlangga.

Benedict, Ruth. 2006. Patterns of Culture. Mariner Books.

Berg-Schlosser, Dirk dan Ralf Rytlewski [Eds.]. 1993. Political Culture in Germany. Palgrave Macmillan.

Bertalanffy, Ludwig Von. 2003. General System Theory: Foundations, Development, Applications. George Braziller Inc.

Bertens, K. 2000. Etika. Jakarta: Gramedia Pustaka Utama.

Blake, Reed H. dan Edwin O. Haroldsen. 2003. Taksonomi Konsep Komunikasi. Terjemahan oleh Hasan Bahanan. Surabaya: Papyrus.

Budiardjo, Miriam. 2008. Dasar-dasar Ilmu Politik. Jakarta: Gramedia Pustaka Utama.

Cangara, Hafied. 2011. Komunikasi Politik: Konsep, Teori dan Strategi. Jakarta: RajaGrafindo Persada.

Chilcote, Ronald H. 1981. Theories of Comparative Political Economy. Westview Press.

Dahl, Robert A. dan Bruce. 2002. Modern Political Analysis. Pearson.

DeVito, Joseph A. 2011. Komunikasi Antarmanusia. Karisma Publishing.

Diamond, Larry. 2003. Dinamika Konsolidasi Demokrasi. Yogyakarta: IRE Press.

Djafar, Massa. 2015. Krisis Politik \& Proposisi Demokratisasi. Jakarta: Bumi Aksara.

Dovring, Karin. 1987. Harold Dwight Lasswell: His Communication With a Future. K. Dovring.

Easton. David. 1965. A Framework for Political Analysis. Prentice-Hall, Inc. . 1965. Systems Analysis of Political Life. John Wiley \& Sons Ltd.

Erikson, Robert dan Kent L. Tedin. 2014. American Public Opinion: Its Origins, Content and Impact. Routledge.

Fagen, Richard R. 1966. Politics and Communication: An Analytic Study. Little Brown \& Company.

Faturohman, Deden dan Wawan Sobari. 2002. Pengantar Ilmu Politik. Malang: UMM Press.

Ferrari, G.R.F. 2005. City and Soul in Plato's Republic. The University of Chicago Press.

Han, Sam dan Kamaludeen Mohamed Nasir. 2015. Digital Culture and Religion in Asia. Routledge.

Hastuti, Sri [Ed.]. 2011. New Media: Teori dan Aplikasi. Surakarta: Lindu Pustaka. 
Heryanto, Gun Gun dan Irwa Zarkasy. 2011. Public Relations Politik. Jakarta: Ghalia Indonesia.

Hikmat, Mahi M. 2010. Komunikasi Politik: Teori dan Praktik (Dalam Pilkada Langsung). Bandung: Simbiosa Rekatama Media.

Husaini, Adian. 2002. Penyesatan Opini: Sebuah Rekayasa Mengubah Citra. Jakarta: Gema Insani Press.

Jefkins, Frank. 2004. Public Relations (Edisi 5). Jakarta: Erlangga.

Johari, Jagdish Chandra. 1972. Comparative Politics. Sterling Publishers.

Kaid, Lynda Lee (Ed.). 2004. Handbook of Political Communication Research. Routledge.

Kantaprawira, Rusadi. 2006. Sistem Politik Indonesia: Suatu Model Pengantar. Bandung: Sinar Baru Algensindo.

Klosko, George. 2012. History of Political Theory: An Introduction: Volume I: Ancient and Medieval. Oxford University Press.

Langeveld, M.J. 1959. Menuju ke Pemikiran Filsafat. Jakarta: PT. Pembangunan.

Lasswell, Harold D. 1936. Politics: Who Gets What, When, How. Peter Smith Pub Inc.

Lasswell, Harold D. dan Abraham Kaplan. 2013. Power and Society: A Framework for Political Inquiry. Transaction Publishers.

Lippmann, Walter. 1998. Opini Umum. Jakarta: Yayasan Obor Indonesia.

Magnis-Suseno, Franz. 1992. Filsafat Sebagai Ilmu Kritis. Yogyakarta: Kanisius. Kanisius.

Makmurtono, Agus dan Munawir. 1989. Etika (Filsafat Moral). Jakarta: Wira Sari.

Manheim, Karl. 1987. Sosiologi Sistematis: Suatu Pengantar Studi Tentang Masyarakat. Jakarta: Bina Aksara.

Masdar, Umaruddin [et al.]. 1999. Mengasah Naluri Publik Memahami Nalar Politik. Yogyakarta; LKiS.

McNair, Brian. 2003. An Introduction to Political Communication (Communication and Society). Routledge.

Mulyana, Deddy. 2013. Komunikasi Politik, Politik Komunikasi: Membedah Visi Dan Gaya Komunikasi Praktisi Politik. Bandung: Remaja Rosdakarya.

Nasuka. 2005. Teori Sistem Sebagai Salah Satu Alternatif Pendekatan dalam Ilmu-Ilmu Agama Islam. Jakarta: Kencana.

Nasution, Zulkarimien. 1990. Komunikasi Politik: Suatu Pengantar. Jakarta: Ghalia Indonesia. 
Nimmo, Dan. 2001. Komunikasi Politik: Khalayak dan Efek. Bandung: Remaja Rosdakarya.

2006. Komunikasi Politik: Komunikator, Pesan dan Media. Terjemahan oleh Jalaluddin Rakhmat. Bandung: Remaja Rosdakarya.

Nurdin, Muslim [et al.]. 1995. Moral dan Kognisi Islam. Bandung: CV. Alfabeta.

Nurudin. 2001. Komunikasi Propaganda. Bandung: Remaja Rosdakarya.

Olii, Helena. 2007. Opini Publik. Jakarta: PT. Indeks.

Pasiak, Taufiq. 2004. Revolusi IQ/EQ/SQ: Menyingkap Rahasia Kecerdasan Berdasarkan Quran dan Teori Neurosains Mutakhir. Bandung: PT. Mizan Publika.

Patterson, Kerry dan Joseph Grenny. 2005. Crucial Conversations - Strategi Menghadapi Percakapan Berisiko Tinggi. Jakarta: Gramedia Pustaka Utama.

Peter, Laurence J. 1986. Piramida Peter: atau Mungkinkah kita Mencapai Puncaknya. Jakarta: Erlangga.

Plano, Jack C., Robert E. Riggs dan Helena S. Robin. 1989. Kamus Analisa Politik. Jakarta: Rajawali.

Purwasito, Andrik. 2011. Pengantar Studi Politik. Surakarta: UNS Press.

R. G. Meadow. 1985. Political Communication Research in the 1980s. Journal of Communication. Volume 35 Issue 1.

Ranney, Austin. 1992. Governing: An Introduction to Political Science. Prentice Hall College.

Rauf, Maswadi dan Mappa Nasrun [Eds.]. 1993. Indonesia dan Komunikasi Politik. Jakarta: Gramedia Pustaka Utama.

Reksosusilo, Stanislaus. 2005. Diktat Kuliah Filsafat Cina. Malang: STFT Widya Sasana.

Rogers, Everett M. 2004. 'Theoritical Diversity in Political Communication'. In Lynda Lee Kaid (Ed.), Handbook Handbook of Political Communication Research. Routledge.

Rosenthal, Erwin Isak Jakob. 2009. Political Thought in Medieval Islam: An Introductory Outline. Cambridge University Press.

Ruck, Anne. 2008. Sejarah Gereja Asia. Jakarta: BPK Gunung Mulia.

Ruslan, Rosady. 2005. Kiat dan Strategi Kampanye Public Relations. Jakarta: RajaGrafindo Persada.

Sanit. Arbi. 2002. Politik, Demokrasi dan Manajemen Komunikasi. Yogyakarta: Galang Press.

Sastropoetro, Santoso. 1990. Komunikasi Sosial. Bandung: Remaja Rosdakarya. 
Shahreza, Mirza. 2017. Komunikator Politik Berdasarkan Teori Generasi. Journal of Communication (Nyimak), Vol. 1, No. 1, 33-48.

Shahreza, Mirza dan Korry El-Yana. 2016. Etika Komunikasi Politik. Tangerang: Indigomedia.

Sobur, Alex. 2001. Etika Pers Profesionalisme dengan Nurani. Bandung : Humaniora Utama Press.

Soemarno dan Rochajat Harun. 2006. Komunikasi Politik: Sebagai Suatu Pengantar. Bandung: Mandar Maju.

Soemarno. 1989. Dimensi-Dimensi Komunikasi Politik. Bandung: Citra Aditya Bakti. 2009. Materi Pokok Komunikasi Politik. Jakarta: Universitas Terbuka.

Soemirat, Soleh dan Elvinaro Ardianto. 2007. Dasar-Dasar Public Relations. Bandung: Remaja Rosdakarya.

Strauss, William dan Neil Howe. 1991. Generations: The History of America's Future, 1584 to 2069. William Morrow \& Co. 1993. 13th Gen: Abort, Retry, Ignore, Fail? Vintage. . 2000. Millennials Rising: The Next Great Generation. Vintage.

Suhandang, Kustadi. 2004. Pengantar Jurnalistik: Seputar Organisasi, Produk dan Kode Etik. Bandung: Nuansa Cendekia.

Suito, Deny. 2006. Membangun Masyarakat Madani. Jakarta: Centre For Moderate Muslim Indonesia.

Surbakti, Ramlan. 1992. Memahami Ilmu Politik. Jakarta: Grasindo.

Susanto, Astrid, S. 1985. Komunikasi Sosial di Indonesia. Bandung: Binacipta.

Suwardi, Arsono [et al.]. 2002. Politik, Demokrasi \& Manajemen Komunikasi. Yogyakarta: Galang Press.

Syah, Sirikit. 2014. Membincang Pers: Kepala Negara dan Etika Media. Jakarta: Elex Media Komputindo.

Tabroni, Roni. 2012. Komunikasi Politik Pada Era Multimedia. Bandung: Simbiosa Rekatama.

Tamburaka, Apriadi. 2013. Literasi Media: Cerdas Bermedia Khalayak Media Massa. Jakarta: Rajawali Pers.

Thompson, George Carslake. 2012. Public Opinion and Lord Beaconsfield (Volume 1). Ulan Press.

Tocqueville, Alexis de. 1990. Democracy in America, Volume 1. Vintage.

Tubbs, Stewart L. dan Sylvia Moss. 2001. Human Communication: Konteks-Konteks Komunikasi (Buku 1). Bandung: Remaja Rosdakarya. 
Umary, Barnawie. 1993. Materia Akhlak. Solo: Ramadhani.

Varma, SP. 1995. Teori Politik Modern. Jakarta: RajaGrafindo Persada.

Weber, Max [et al.]. 1947. The Theory of Social and Economic Organization. Oxford University Press.

West, Richard dan Lynn H. Turner. 2008. Pengantar Teori Komunikasi: Analisis dan Aplikasi (Buku 1). Jakarta: Salemba Humanika.

Wibowo, Eddi [et al.]. 2004. Ilmu Politik Kontemporer. Yogyakarta: YPAPI.

Wiseman, H. Victor. 1966. Political Systems : Some Sociological Approaches. Praeger.

Young, Oran R. 1968. Systems of Political Science (Foundations of Modern Political Science Series). Prentice-Hall.

Yu-Lan, Fung. 2007. Sejarah Filsafat Cina. Yogyakarta: Pustaka Pelajar.

\section{Tentang penulis}

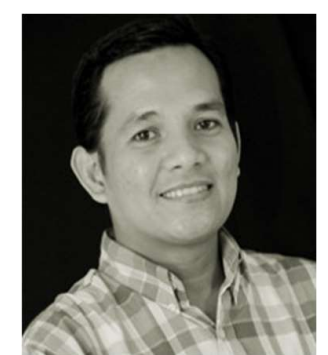

Mirza Shahreza, S.I.Kom, M.I.K. Lahir di Jakarta, 29 Juli 1976. Bertempat tinggal domisili di daerah Rempoa, Tangerang Selatan, Banten. Menyelesaikan S1 IImu Komunikasi dari Universitas Terbuka (UT) pada tahun 2012 dan S2 Komunikasi Politik pada Sekolah Pascasarjana Universitas Muhammadiyah Jakarta (UMJ) pada tahun 2014. Saat ini sebagai dosen tetap di Fakultas IImu Sosial dan IImu Politik (FISIP) Universitas Muhammadiyah Tangerang (UMT).

Pengalaman mengajar pernah mengampu mata kuliah komunikasi politik, Komunikasi massa, komunikasi antar budaya dan Teori Komunikasi pada Universitas Muhammadiyah Tangerang (2014 - sekarang) dan FISIP Universitas Pembangunan Nasional "Veteran" Jakarta (UPNVJ) (2012-2015). Saat ini sedang menempuh pendidikan pascasarjana S3 Komunikasi Pembangunan Pedesaan dan Pertanian di Institut Pertanian Bogor angkatan 2017.

Keterlibatan dalam organisasi menjadi pengurus Ikatan Sarjana Komunikasi Indonesia (ISKI) Pusat sebagai wakil ketua bidang keanggotaan periode 2013 - 2017, sebagai ketua dewan Pembina Yayasan Desa Hijau (YDH) sejak 2011 - sekarang, dan kordinator Association of The Creator's Code Breakers (ACCB) sejak 2009 - sekarang. 